\title{
Open Skies Aerial Photography of Selected Areas in Central America Affected by Hurricane Mitch
}

\section{U.S. Geological Survey Circular 1181}

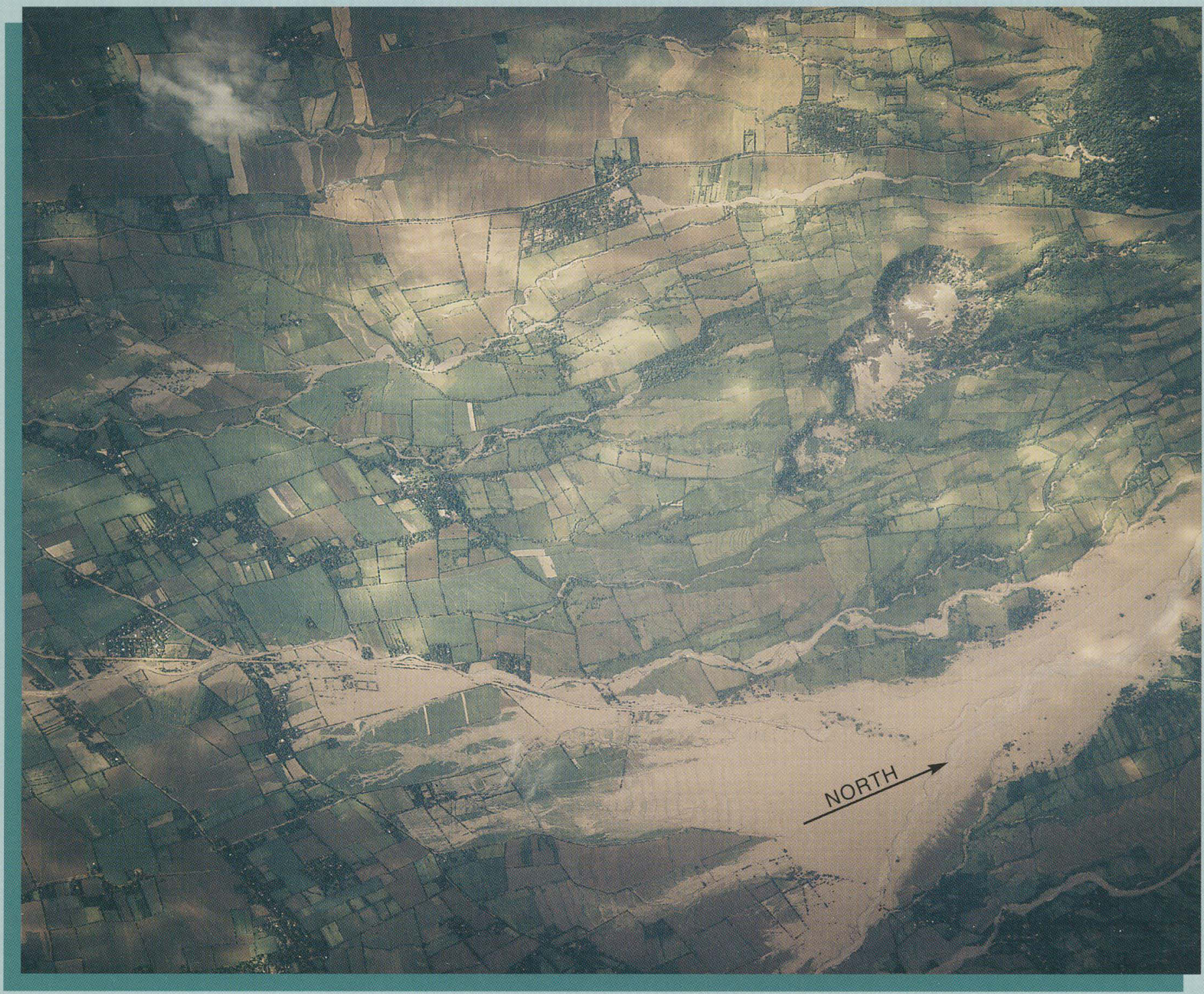




\section{Open Skies Aerial Photography of Selected Areas in Central America Affected by Hurricane Mitch}

By Bruce F. Molnia and Cheryl A. Hallam

U.S. Geological Survey Circular 1181 


\title{
U.S. DEPARTMENT OF THE INTERIOR \\ BRUCE BABBITT, Secretary
}

\author{
U.S. GEOLOGICAL SURVEY \\ CHARLES G. GROAT, Director
}

UNITED STATES GOVERNMENT PRINTING OFFICE, WASHINGTON : 1999

Published in the Eastern Region, Reston, Va.

Manuscript approved for publication March 16, 1999

Any use of trade, product, or firm names in this publication is for descriptive purposes only and does not imply endorsement by the U.S. Government

Free on application to

U.S. Geological Survey

Information Services

Box 25286, Federal Center

Denver, CO 80225

Library of Congress Cataloging in Publication Data

Molnia, Bruce.

Open skies aerial photography of selected areas in Central America affected by Hurricane Mitch / by Bruce F. Molnia and Cheryl A. Hallam.

p. cm. - (U.S. Geological Survey circular; 1181)

Includes index.

Supt. of Docs. no.: I 19.4/2:1181

1. Hurricane Mitch, 1998 Pictorial works. 2. Hurricanes-Central

America Pictorial works. I. Hallam, Cheryl A. II. Title.

III. Series.

QC945.M66 1999

363.34'92281'09728022-dc21 


\section{FOREWORD}

Today, hurricanes can be one of the most deadly and destructive natural disasters to strike a community, leaving in the aftermath the need for critical decisions to be made about rebuilding and planning for disaster resilient communities.

In the wake of Hurricane Mitch, which devastated Central America last year, the U.S. Geological Survey and the U.S. Defense Threat Reduction Agency's Open Skies project joined forces to provide more than 15,000 aerial photographic images of the devastated region to the U.S. Hurricane Mitch Reconstruction Task Force and many others working on the reconstruction effort.

Images obtained through the Open Skies Project have proved to be an invaluable tool for those involved in rebuilding the communities. For instance, scientists are using the images to get a clear and timely picture of the location and occurrence of landslides and floods, agricultural damage, and damage to offshore reefs, as well as changes in current land use owing to debris flows and floods. As the reconstruction efforts continue, planners will be able to use this critical information to help make informed decisions as they rebuild and ensure that communities will be less susceptible to future natural disasters.

This cooperative effort is a clear demonstration of the value of combining the capabilities of two agencies not usually seen as having complementary skills and needs.

This is a lesson we need to take into the future.

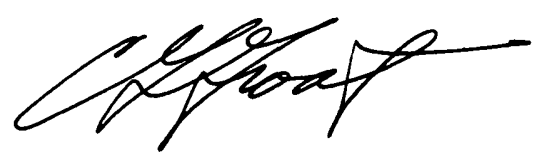

Charles G. Groat

Director, U.S. Geological Survey 


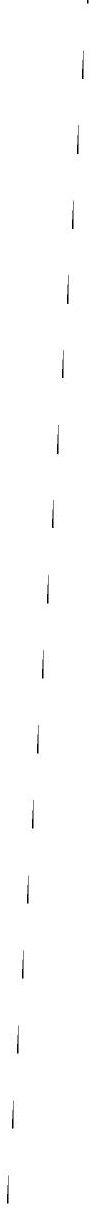




\section{CONTENTS}

Foreword

Introduction .1

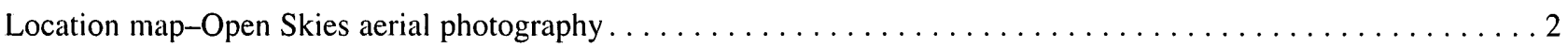

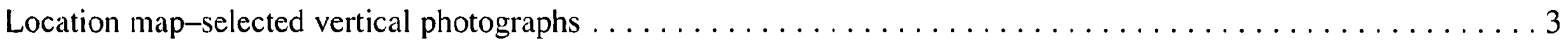

\section{Selected vertical photographs (with topographic maps)}

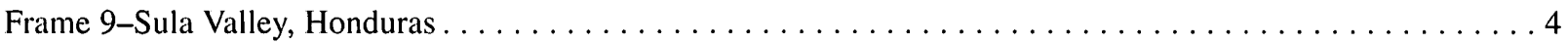

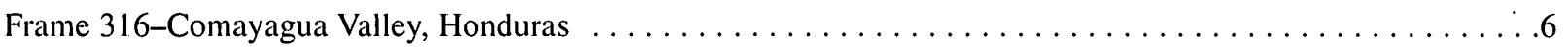

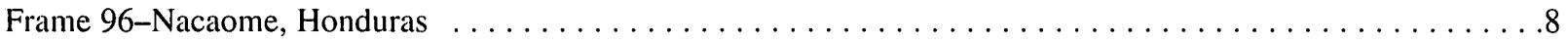

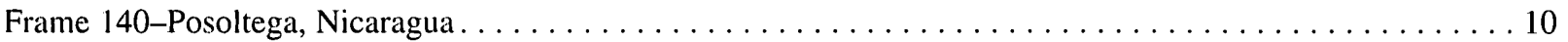

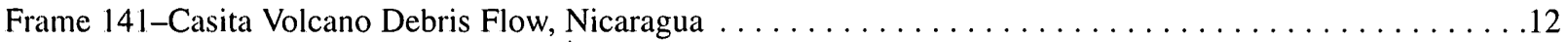

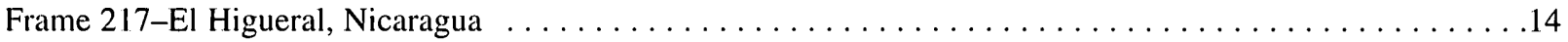

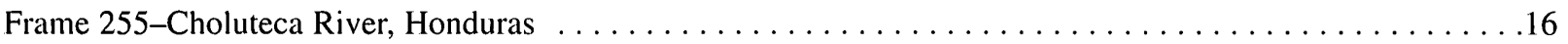

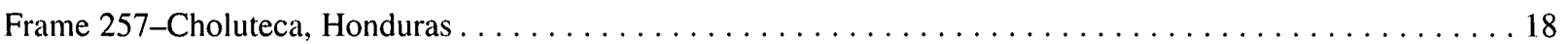

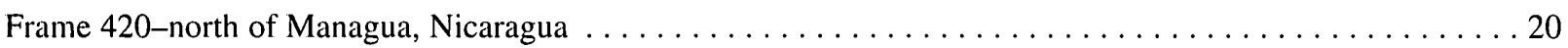

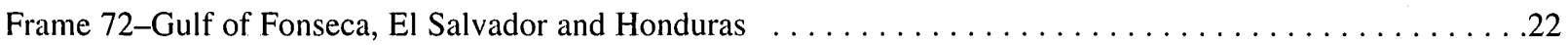

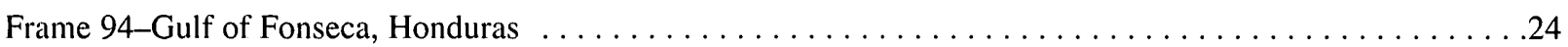

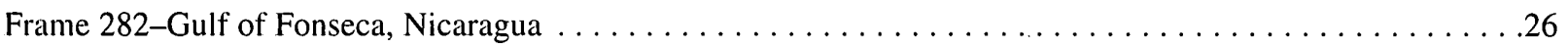

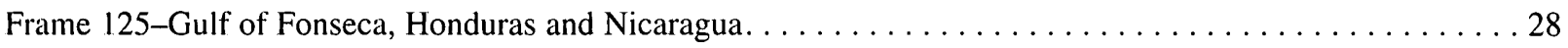

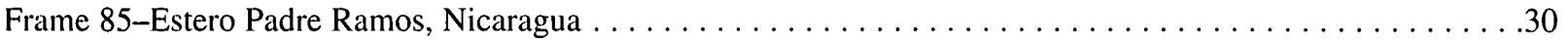

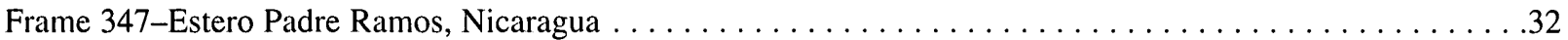

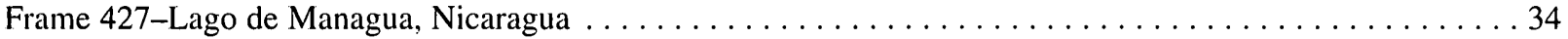

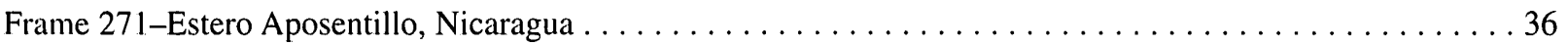

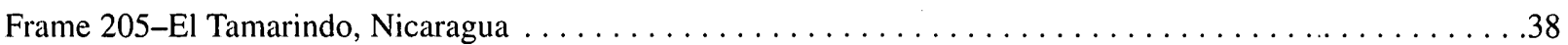

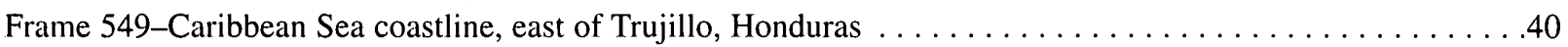

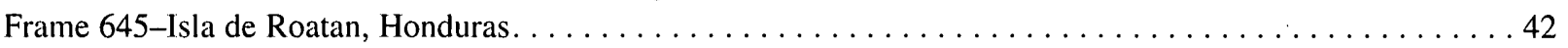

Examples of the information content in the Open Skies photography $\ldots \ldots \ldots \ldots \ldots \ldots \ldots \ldots \ldots \ldots 44$

Enlargements of the Casita Volcano debris flow, Posoltega, Nicaragua-Frame $140 \ldots \ldots \ldots \ldots \ldots \ldots \ldots 45$

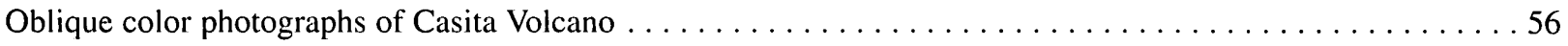

Enlargements of the Casita Volcano debris flow, Posoltega, Nicaragua-Frame $141 \ldots \ldots \ldots \ldots \ldots \ldots .57$

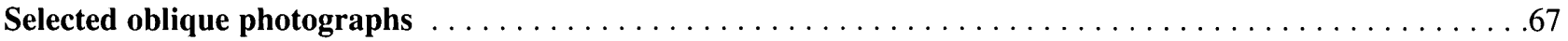

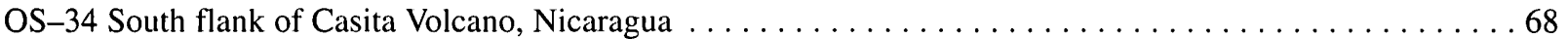

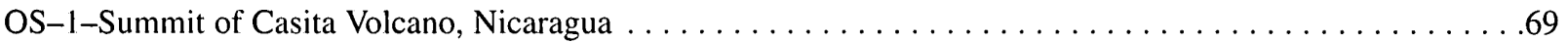

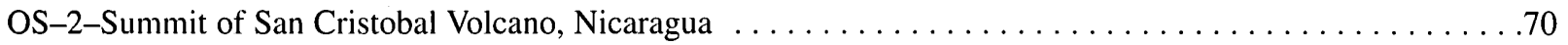

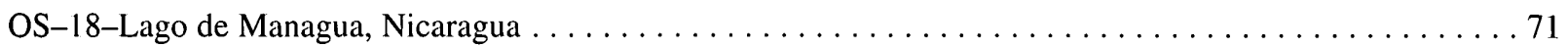

OS-32-Honduras-Nicaraguan border area, northeast of Choluteca $\ldots \ldots \ldots \ldots \ldots \ldots \ldots \ldots \ldots \ldots \ldots \ldots$

OS-12-Honduras-Nicaraguan border area, north of Chinandega $\ldots \ldots \ldots \ldots \ldots \ldots \ldots \ldots \ldots \ldots \ldots$

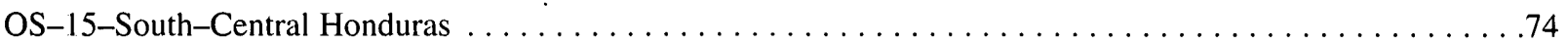

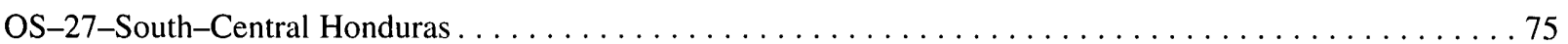

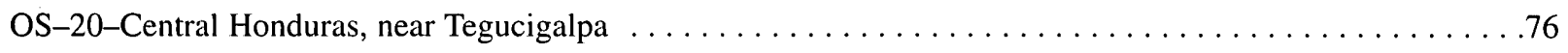

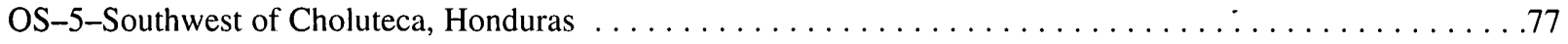

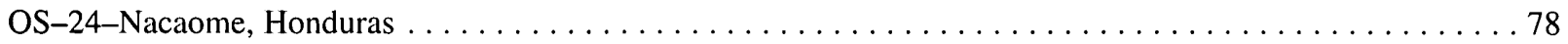

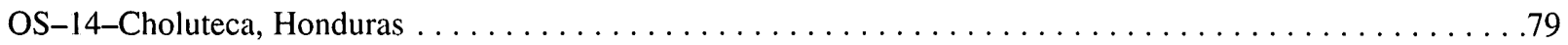

OS-23-Choluteca River, north of Marcovia, Honduras $\ldots \ldots \ldots \ldots \ldots \ldots \ldots \ldots \ldots \ldots \ldots \ldots \ldots$

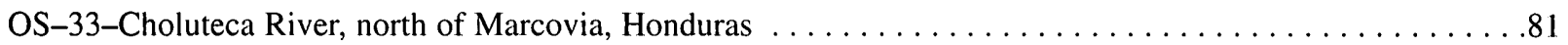

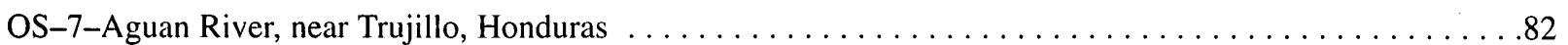




\section{Open Skies Aircraft}

\section{Used For The Missions To Central America}

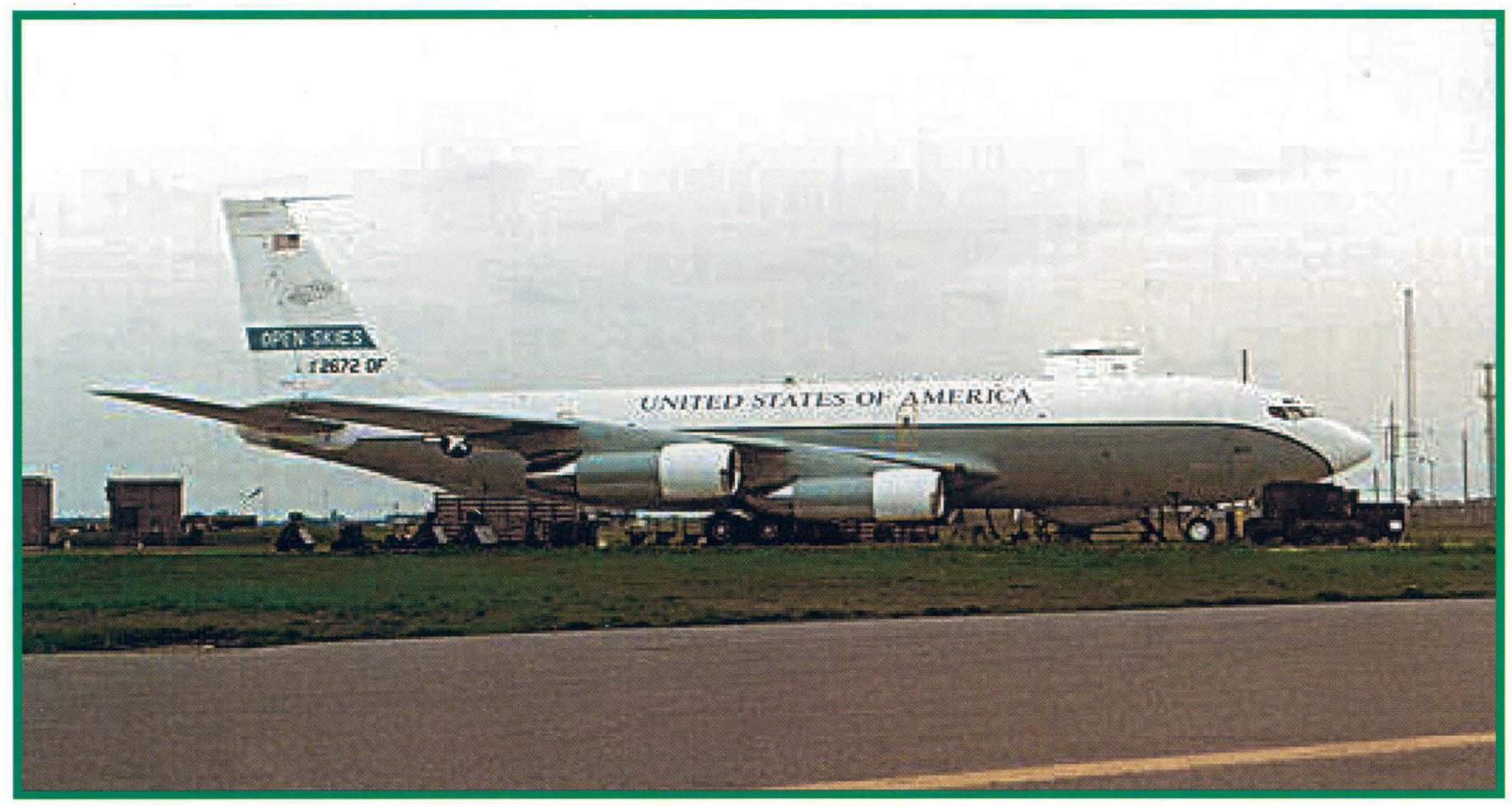




\title{
Open Skies Aerial Photography of Selected Areas in Central America Affected by Hurricane Mitch
}

\author{
By Bruce F. Molnia and Cheryl A. Hallam
}

\section{INTRODUCTION}

Between October 27 and November 1, 1998, Central America was devastated by Hurricane Mitch, a force five Hurricane-one of the most destructive hurricanes in the recorded history of the western hemisphere. Honduras, Nicaragua, El Salvador, and Guatemala all suffered significant damage. Parts of Honduras received more than 6 feet of rain. Many areas were subjected to winds of more than 180 miles per hour. More than 11,000 lives were lost as a result of the severe floods and landslides caused by the storm.

Following a U.S. Government humanitarian relief effort, many Federal agencies joined together to form a "Hurricane Mitch Reconstruction Task Force," designed to provide aid and assistance to the affected Central American countries. One of the first informational needs was complete aerial photographic coverage of the stormravaged areas. These images were needed by the governments of the affected countries, by the U.S. agencies planning to provide assistance, and by the international relief community, including many donor agencies, poised to come to the aid of the residents of the devastated area.

To meet this need, a partnership was formed between the U.S. Geological Survey (USGS) of the Department of the Interior and the Open Skies Program (OS) of the Defense Threat Reduction Agency (DTRA). Between December 4 and 19, 1998, an Open Skies aircraft, flown by U.S. Air Force personnel, conducted five successful missions to Central America. Each flight included USGS scientists to provide scientific advice to the OS mission team.

Despite storms and constraints posed by heavy cloudcover, the missions obtained more than 5,000 high-resolution aerial photographs and more than 15,000 video images over many of the most severely affected areas. These aerial data are being used by the Reconstruction Task Force and many others who are working to begin rebuilding and to help reduce the risk of future destruction.

As the Nation's largest water-, earth-, and biological science and civilian mapping agency, the USGS works in cooperation with more than 2,000 organizations across the country to provide reliable, impartial scientific information to resource managers, planners, and other customers. This information is gathered by USGS scientists to minimize the loss of life and property from natural disasters; contribute to the sound conservation, econom- ic, and physical development of the Nation's natural resources; and enhance the quality of life by monitoring water, biological, energy, and mineral resources.

$O S$ is an international effort designed to enhance mutual understanding and confidence with respect to military armaments. On March 24, 1992, the United States, along with 26 other nations, signed the Treaty on Open Skies as part of a wide-ranging international effort to promote the openness of military forces and activities. The Treaty gives all participant nations, regardless of size, a direct role in gathering information about military forces and activities of concern to them in other Treaty countries.

The Treaty identifies a standard suite of remote-sensing equipment that can be used for verification by all participating countries. An Open Skies observation aircraft, with its remote-sensing data-collection capability, was made available to the USGS by DTRA, with approval of the National Security Council. Flights were made on December 4, 9, 10, 15, and 19, 1998, using an OC-135B aircraft.

Photographs and images were collected with several different OS optical cameras, including one vertically mounted framing camera, one panoramic camera, and one video camera. Both black-and-white and color photographs were made and are currently being used to assess damage, to plan and prioritize response, and to do scientific analysis. Additionally, USGS geologists obtained color oblique photographs of many of the storm-affected areas using hand-held $35 \mathrm{~mm}$ cameras. Both vertical and oblique photographs will be made available to all interested parties using CD-ROM's and the World Wide Web. For distribution information, see the USGS web site at http://www.usgs.gov.

Individual black-and-white vertical photographs cover an area of about 50 square miles. These photographs can be digitally or photographically enlarged more than 50 times to reveal detailed information about natural features and manmade structures, such as individual buildings and bridges. It is at these enlarged scales that these OS photographs are being used for assessing damage and for future planning.

This book was prepared with the assistance of many CINDI and other USGS staff members. Digital scanning of the OS Central American photography was performed by the USGS EROS Data Center, Sioux Falls, S. Dak., the USGS Mapping Applications Center, Reston, Va., and the DTRA. 


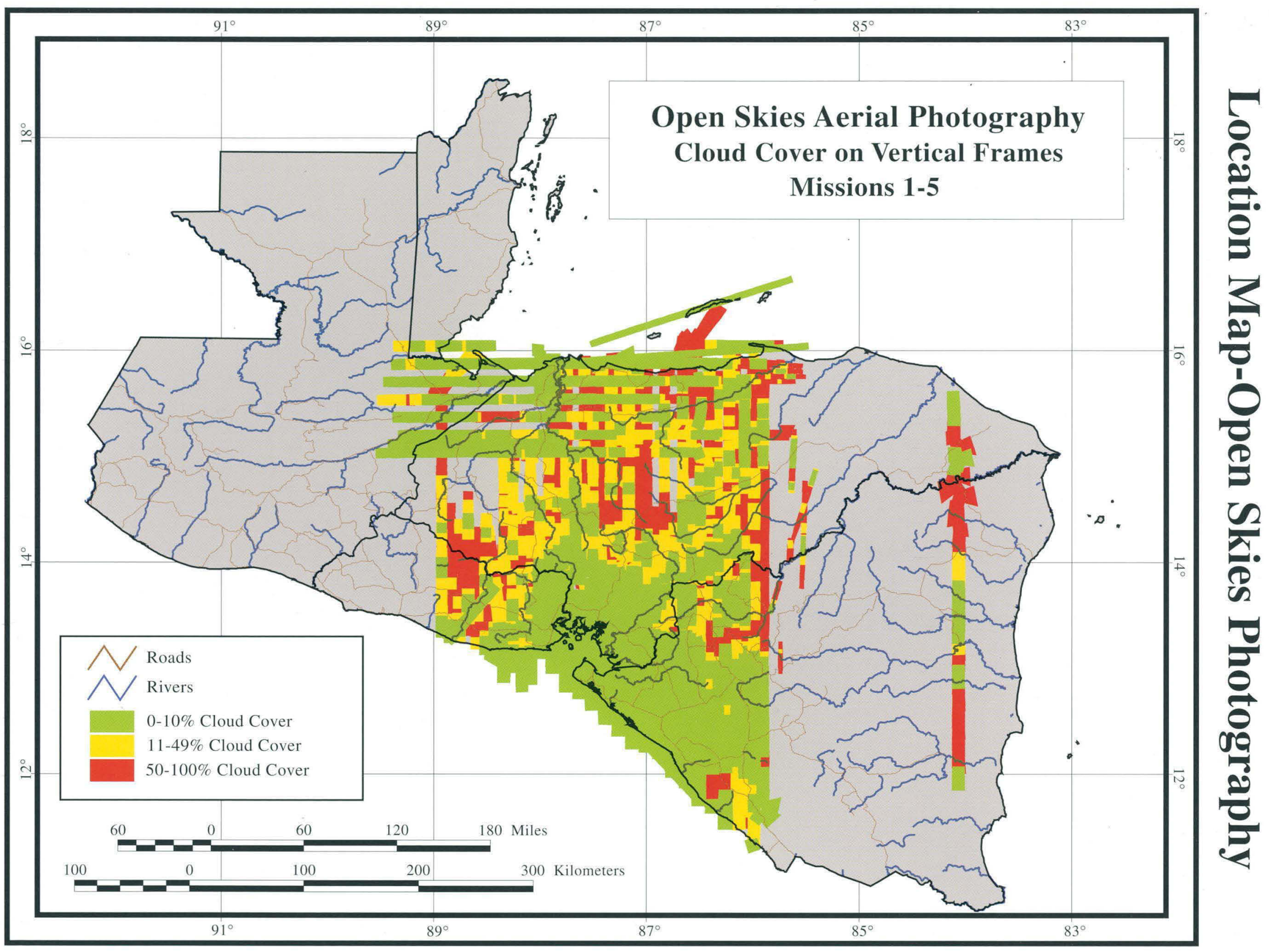




\section{Open Skies Aerial Photography}

\section{Index to Selected Frames}

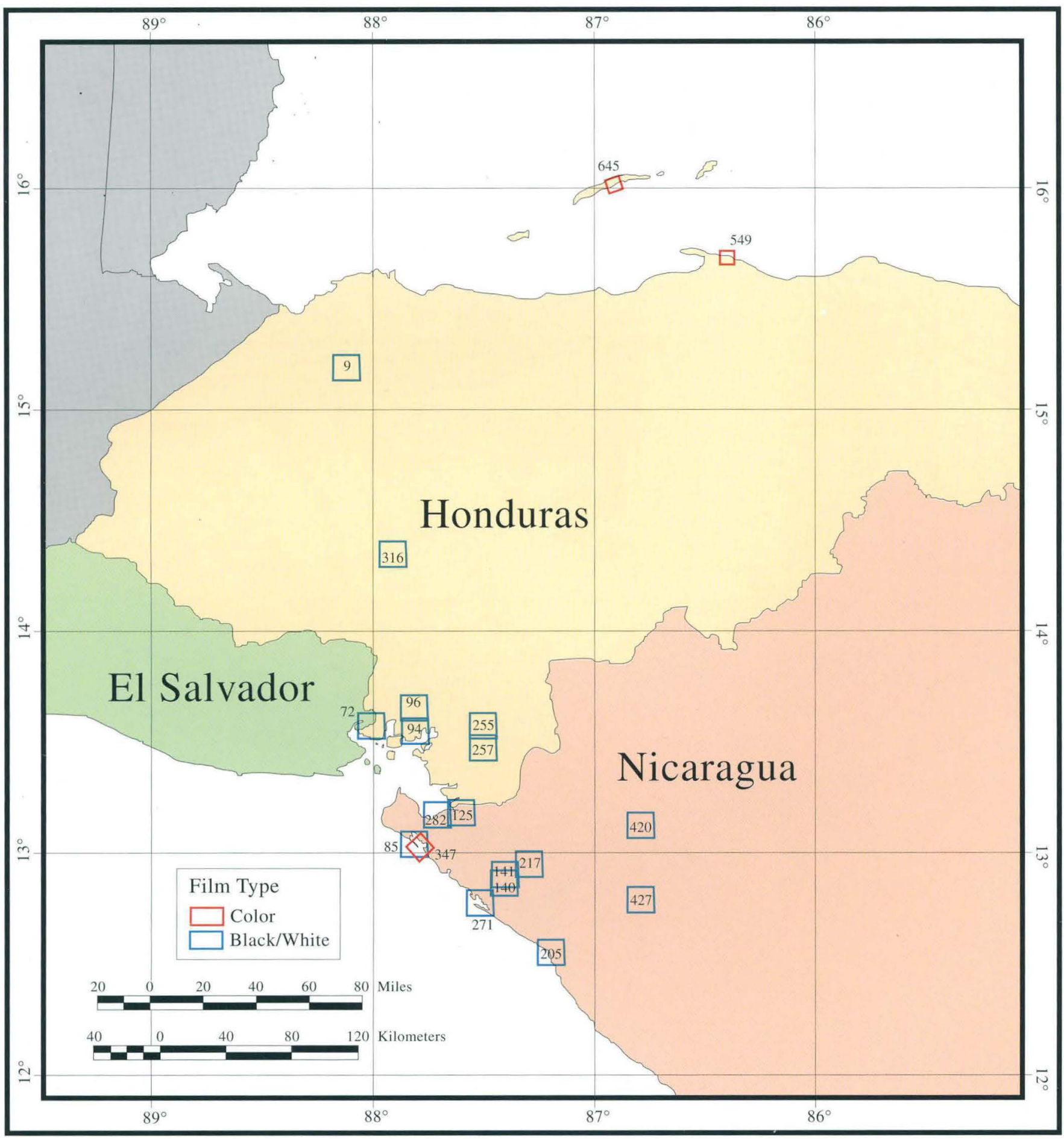




\section{Topographic map corresponding to}

\section{Frame 9-December 4, 1998-12:43:50}

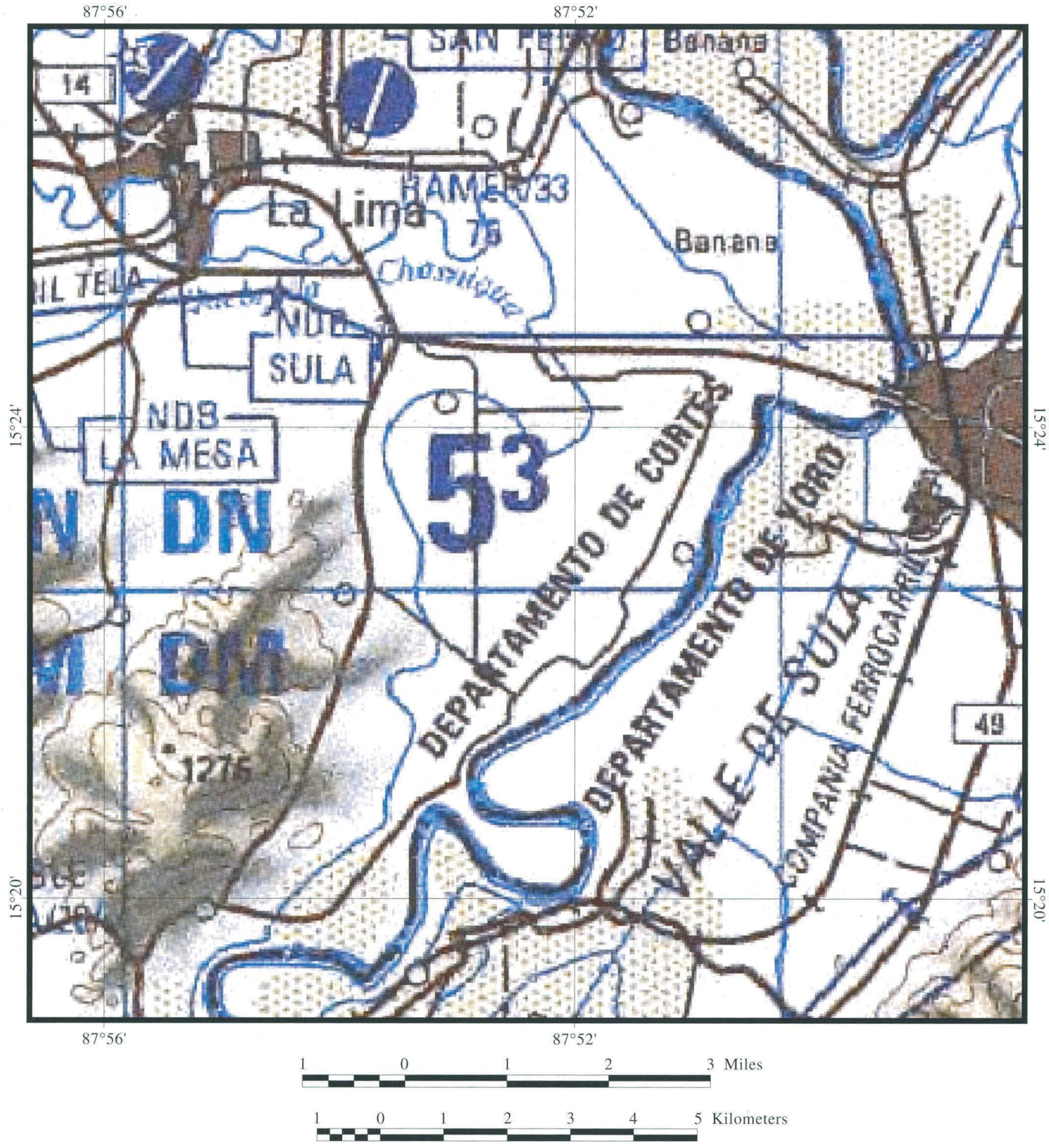

Map Source: 1:250,000-scale DMA topographic maps of Central America 


\section{Sula Valley, Honduras}

\section{Frame 9-December 4, 1998-12:43:50}

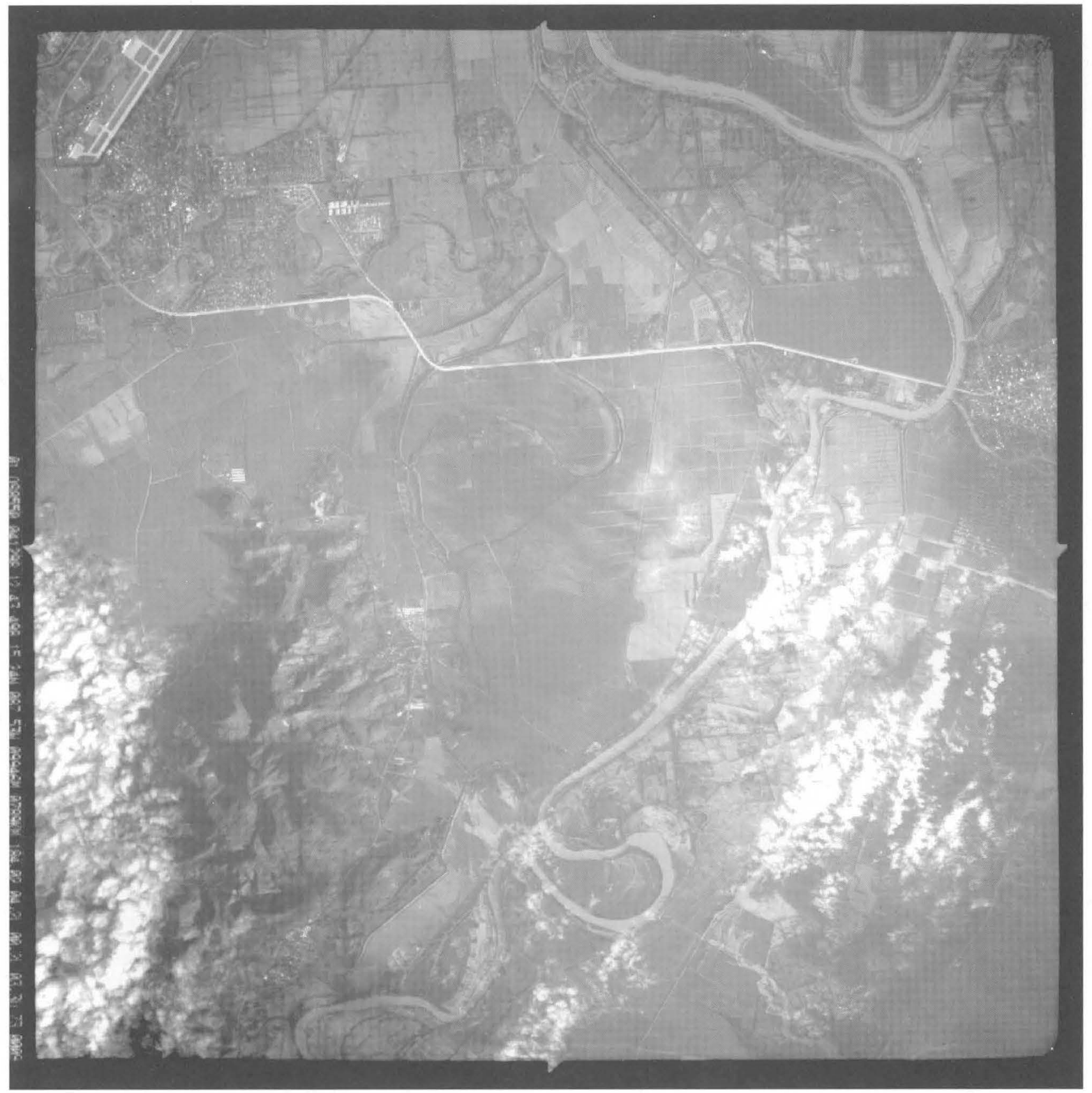

Black-and-white vertical photograph of the Sula Valley and the La Lima - El Progreso area southeast of San Pedro Sula, Honduras. Much of the land adjacent to the meandering Ulua River was flooded. Some of the farm fields and banana groves in the Sula Valley

still show evidence of having standing water, more than a month following the storm. 


\section{Topographic map corresponding to}

\section{Frame 316-December 4, 1998-16:04:46}

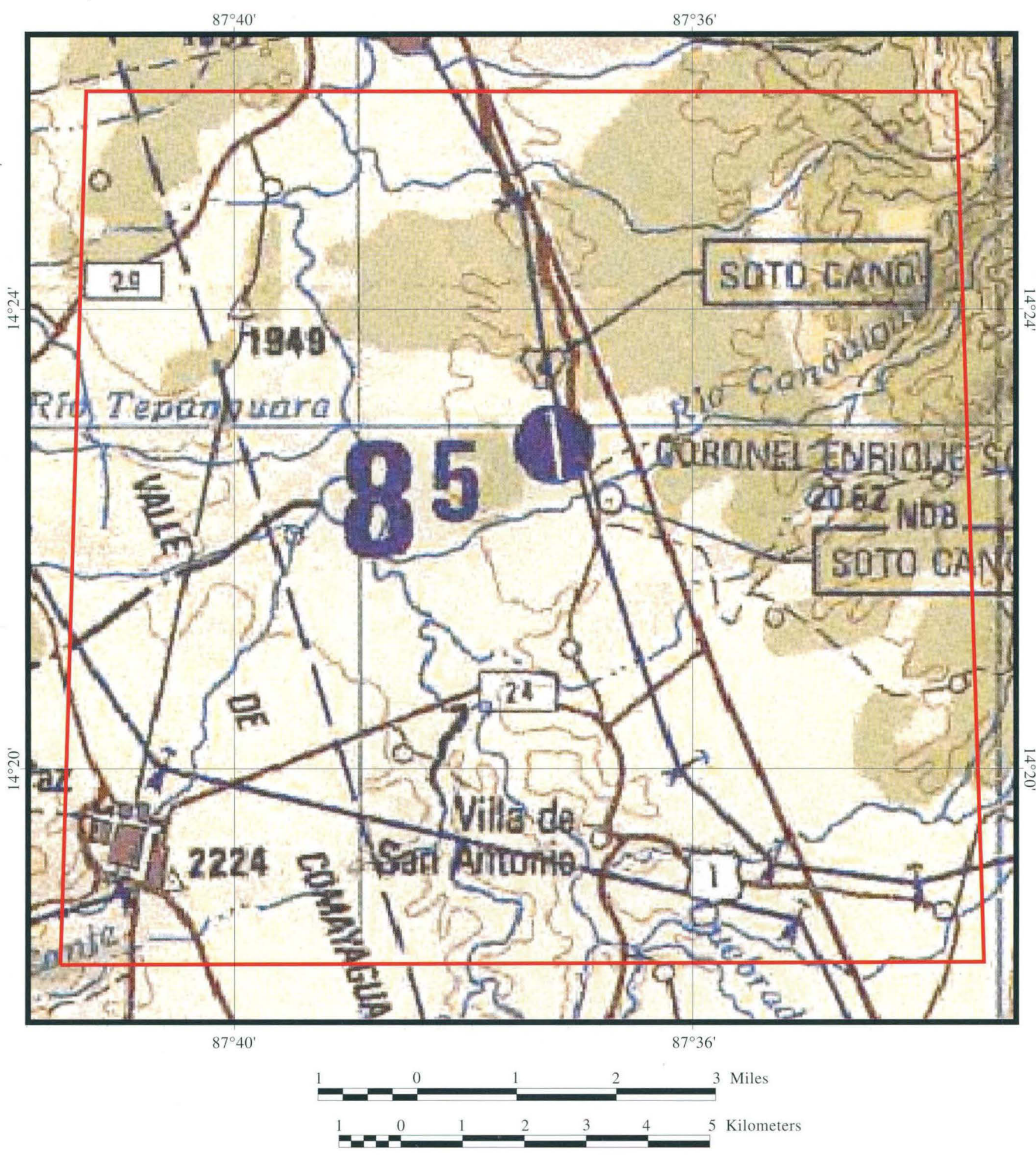

Map Source: 1:250,000-scale DMA topographic maps of Central America 


\section{Comayagua Valley, Honduras}

\section{Frame 316-December 4, 1998-16:04:46}

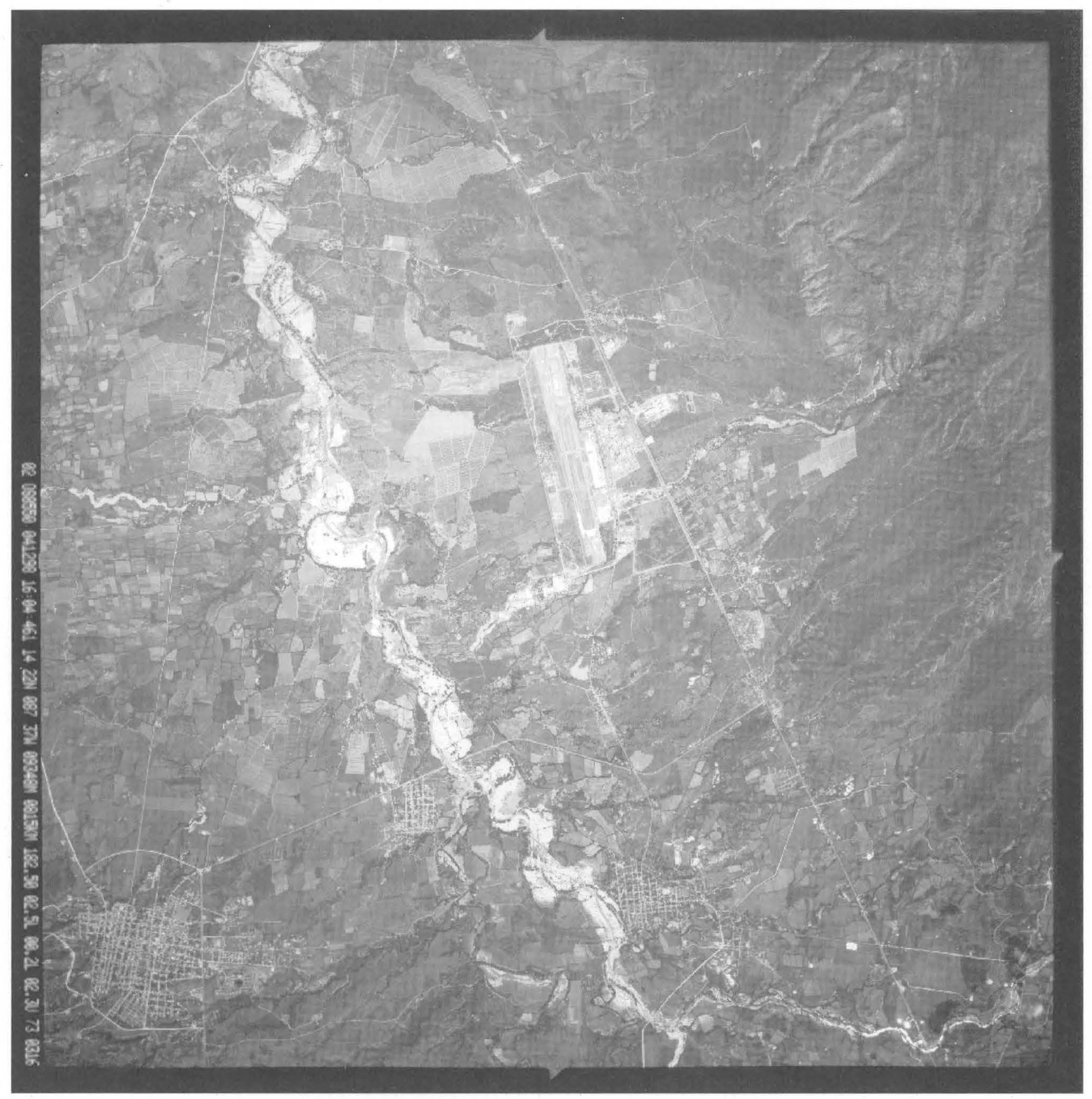

Black-and-white vertical photograph of the Comayagua Valley, in central Honduras, in the vicinity of La Paz and Villa de San Antonio. The west side of Villa de San Antonio was flooded. Large quantities of sediment were deposited in the town, along the banks, and on the floodplain of the Rio Tepanguaro and the other large rivers in the area. 


\section{Topographic map corresponding to}

\section{Frame 96-December 4, 1998-13:43:44}

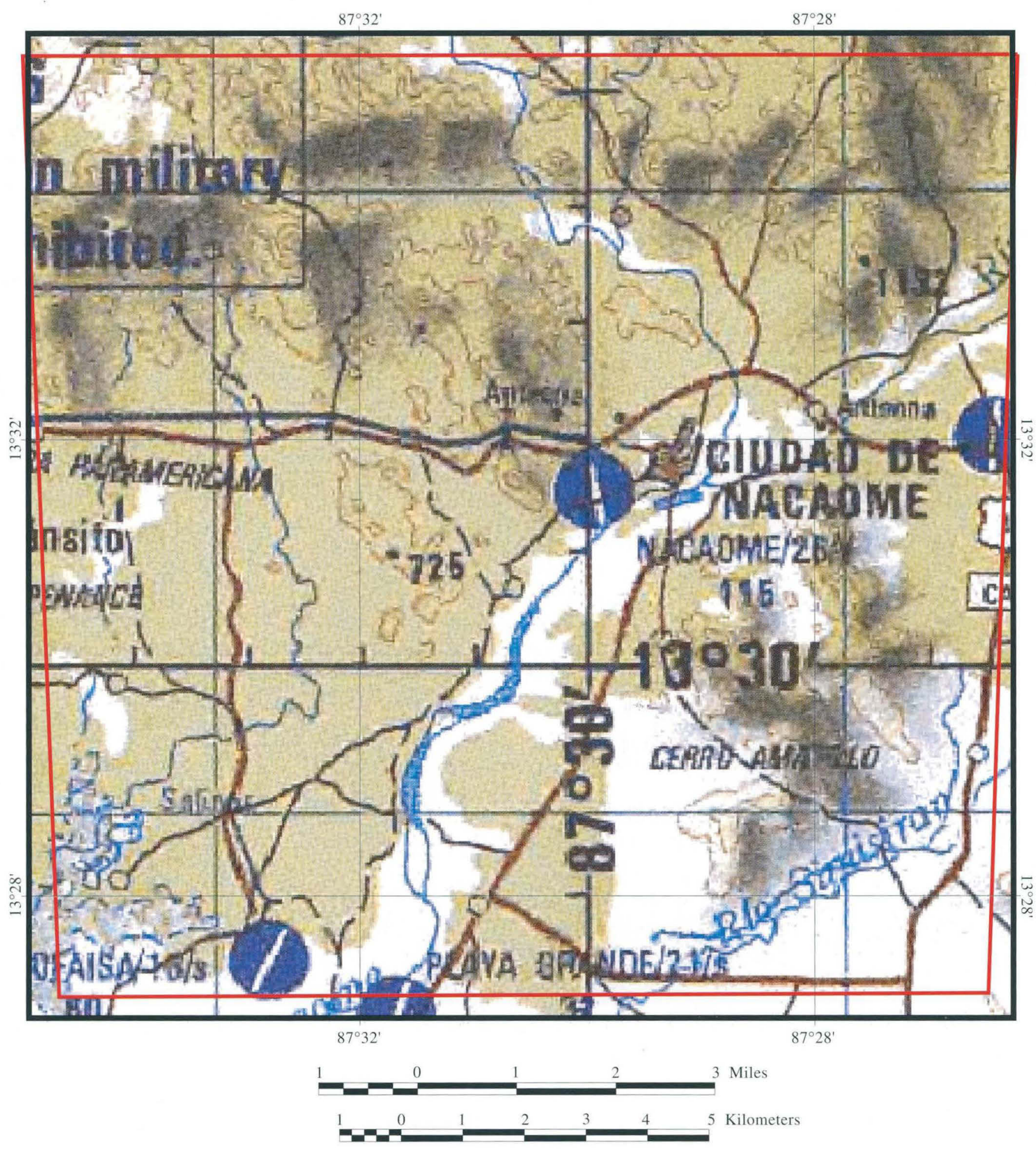




\section{Nacaome, Honduras}

\section{Frame 96-December 4, 1998-13:43:44}

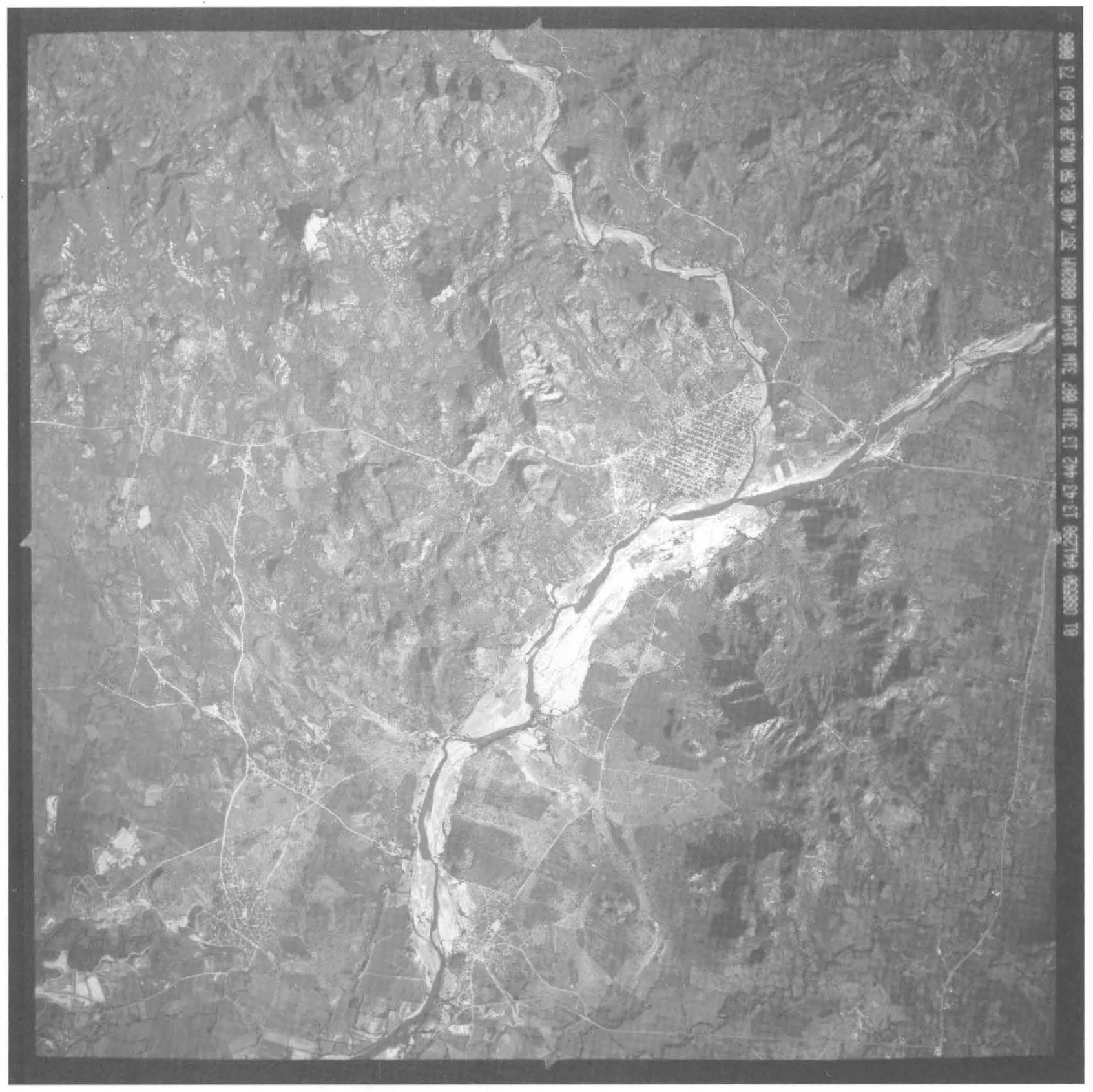

Black-and-white vertical photograph of southern Honduras near the city of Nacaome. Flooding deposited large quantities of sediment along the banks and on the floodplain of the Rio Nacaome, especially in the southern half of the area shown in the photograph. Many manmade structures on the floodplain were destroyed, and much of the city and adjacent farmland was flooded. 


\section{Topographic map corresponding to}

Frame 140-December 4, 1998-14:19:50

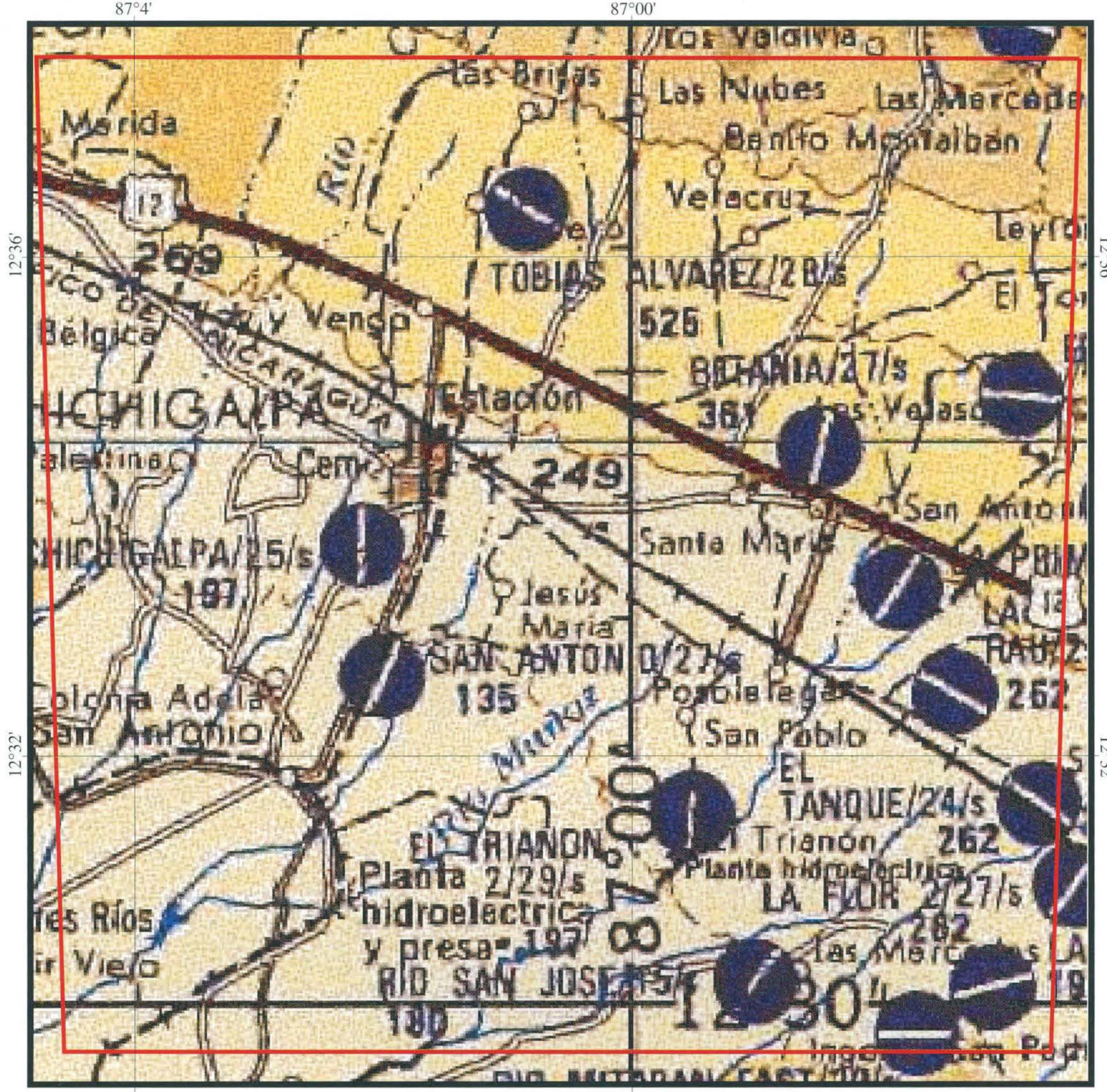

$87^{\circ} 4^{\prime}$ 


\section{Posoltega, Nicaragua}

\section{Frame 140-December 4, 1998-14:19:50}

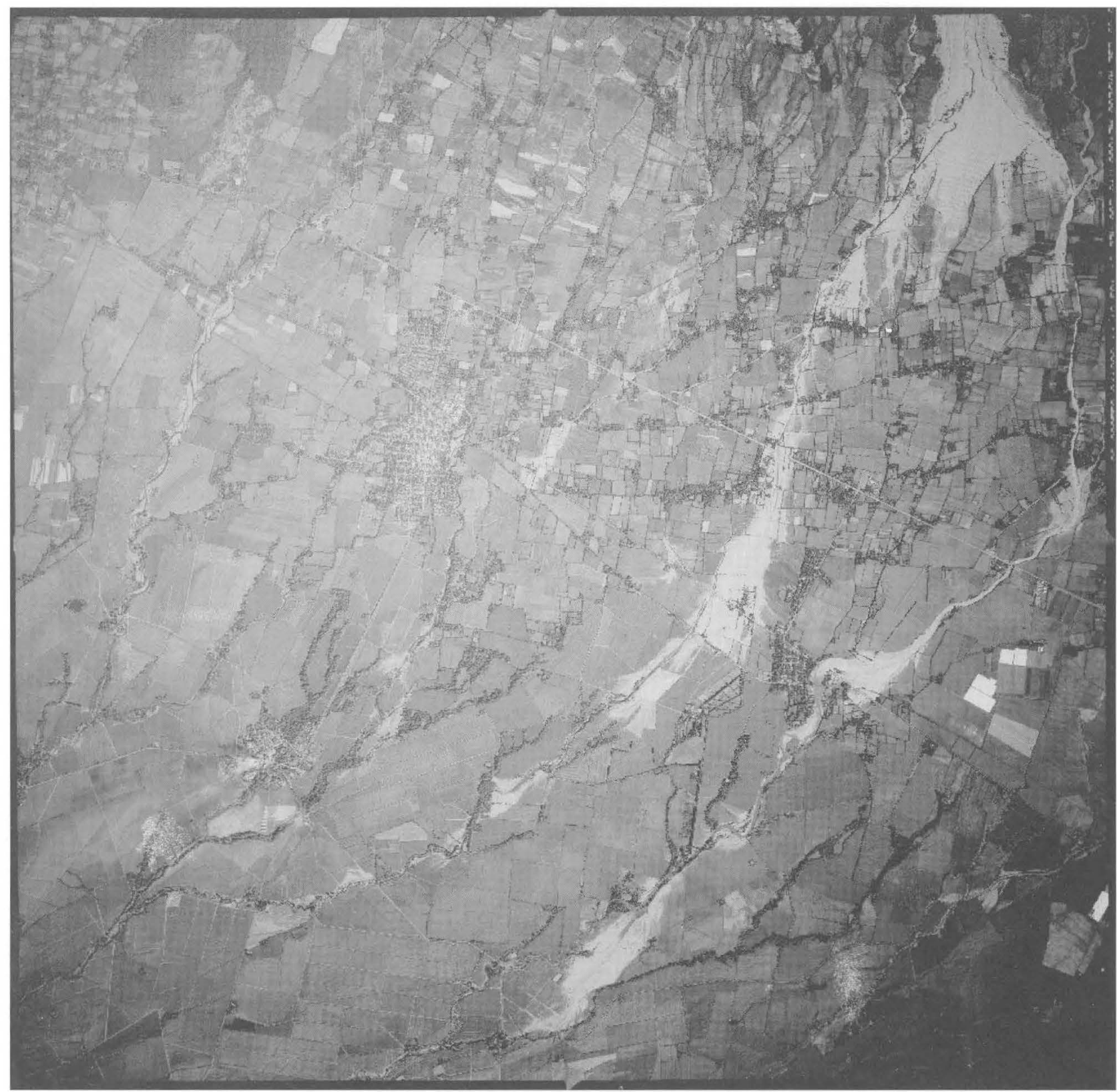

Black-and-white vertical photograph of the area south of Casita Volcano showing the lower $3 / 4$ of the large bifurcating volcanic debris flow that destroyed the villages of El Porvenir and Rolando Rodriguez, killing about 2,500 people. Both villages were located in the Municipality of Posoltega, Nicaragua. The large triangular debris flow in the top right corner of the photograph originated as a rock avalanche from the southeast flank of the volcano. It contained more than 200,000 cubic yards of sediment and traveled about five miles prior to bifurcating. The flows continued downslope in existing channels before covering and breaching the InterAmerican Highway and the local railroad line. The eastern limb reached the village of Posoltega, where it destroyed houses on the east side of town. (See enlargements beginning on page 45.) Sediment deposited by the debris flow also buried many agricultural fields. Combine this photograph with photograph 141 to see the entire debris flow. 


\section{Topographic map corresponding to}

\section{Frame 141-December 4, 1998-14:20:17}

$87^{\circ} 4$

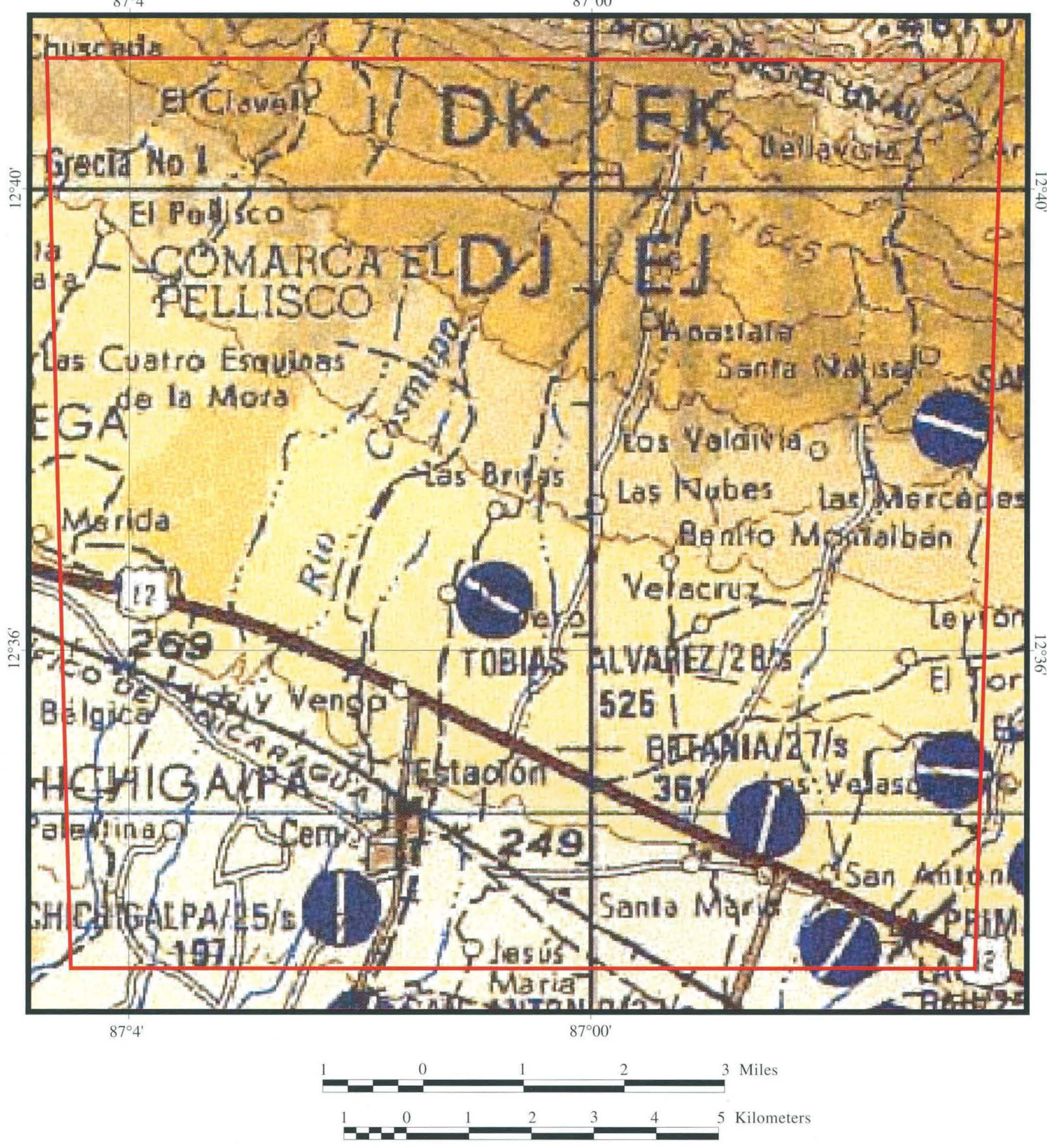

Map Source: 1:250,000-scale DMA topographic maps of Central America 


\section{Casita Volcano Debris Flow, Nicaragua}

\section{Frame 141-December 4, 1998-14:20:17}

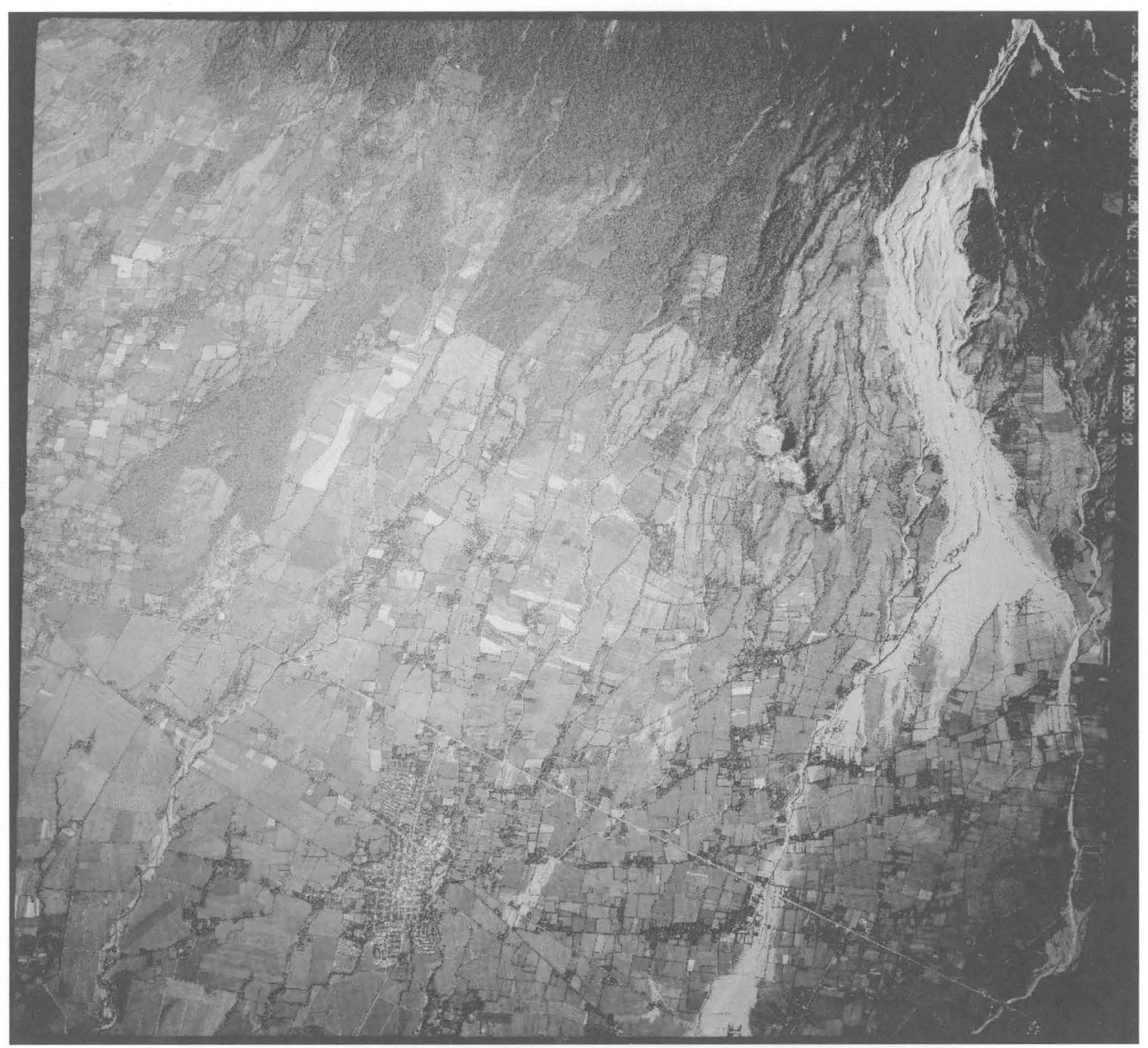

Black-and-white vertical photograph of the south flank of Casita Volcano showing the head and upper two-thirds of the large volcanic debris flow that destroyed the villages of El Porvenir and Rolando Rodriguez, killing about 2,500 people. Both villages were located in the Municipality of Posoltega, Nicaragua. The debris flow originated as a rock avalanche from the southeast flank of the volcano. It contained more than 200,000 cubic yards of sediment and traveled about 5 miles prior to bifurcating. The debris flows then continued downslope covering and breaching the Inter-American Highway and the local railroad line. (See enlargements beginning on page 57.) Sediment deposited by the debris flow also buried many agricultural fields. Combine this photograph with photograph 140 to see the entire debris flow. 


\section{Topographic map corresponding to}

\section{Frame 217-December 4, 1998-15:05:02}

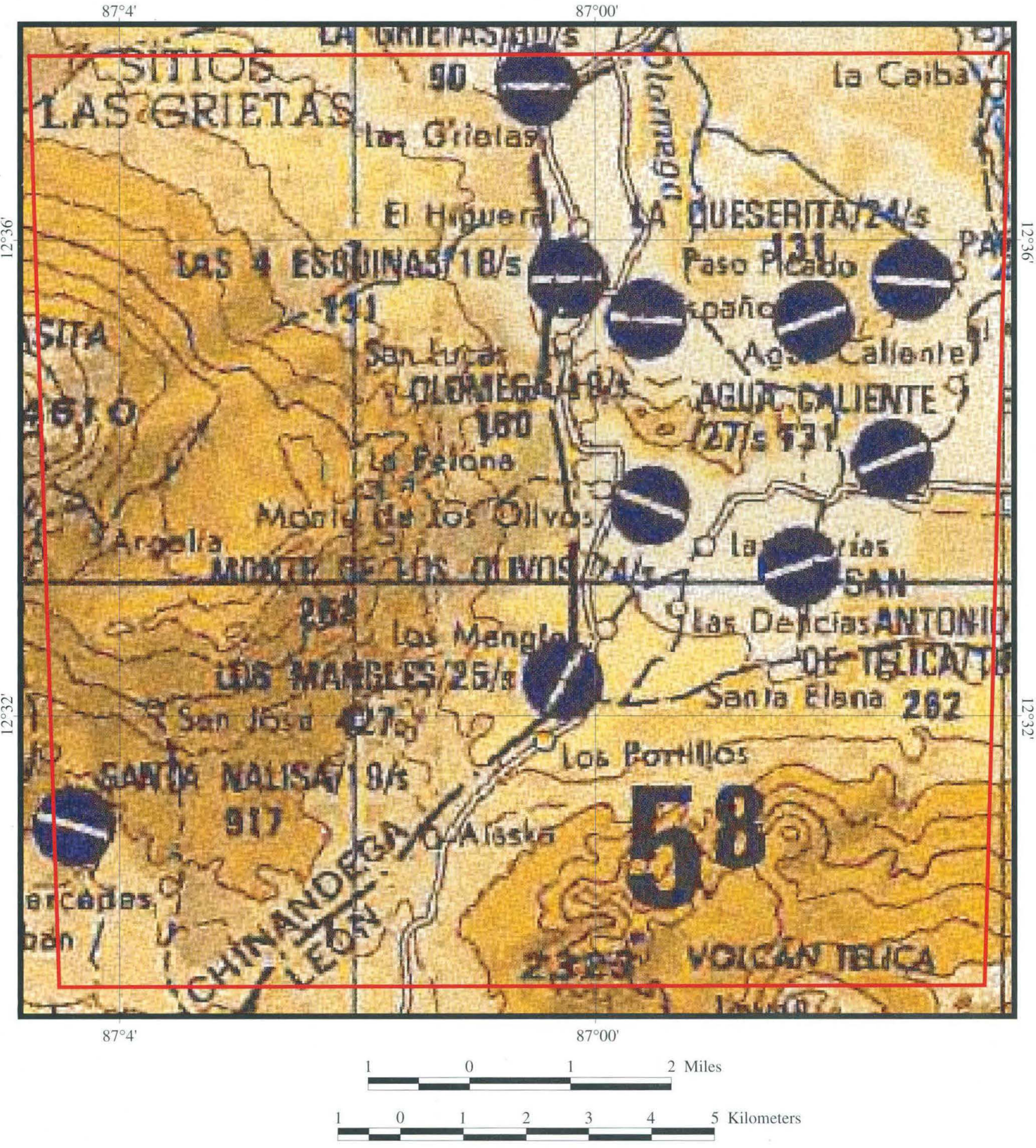

Map Source: 1:250,000-scale DMA topographic maps of Central America 


\section{El Higueral, Nicaragua}

\section{Frame 217-December 4, 1998-15:05:02}

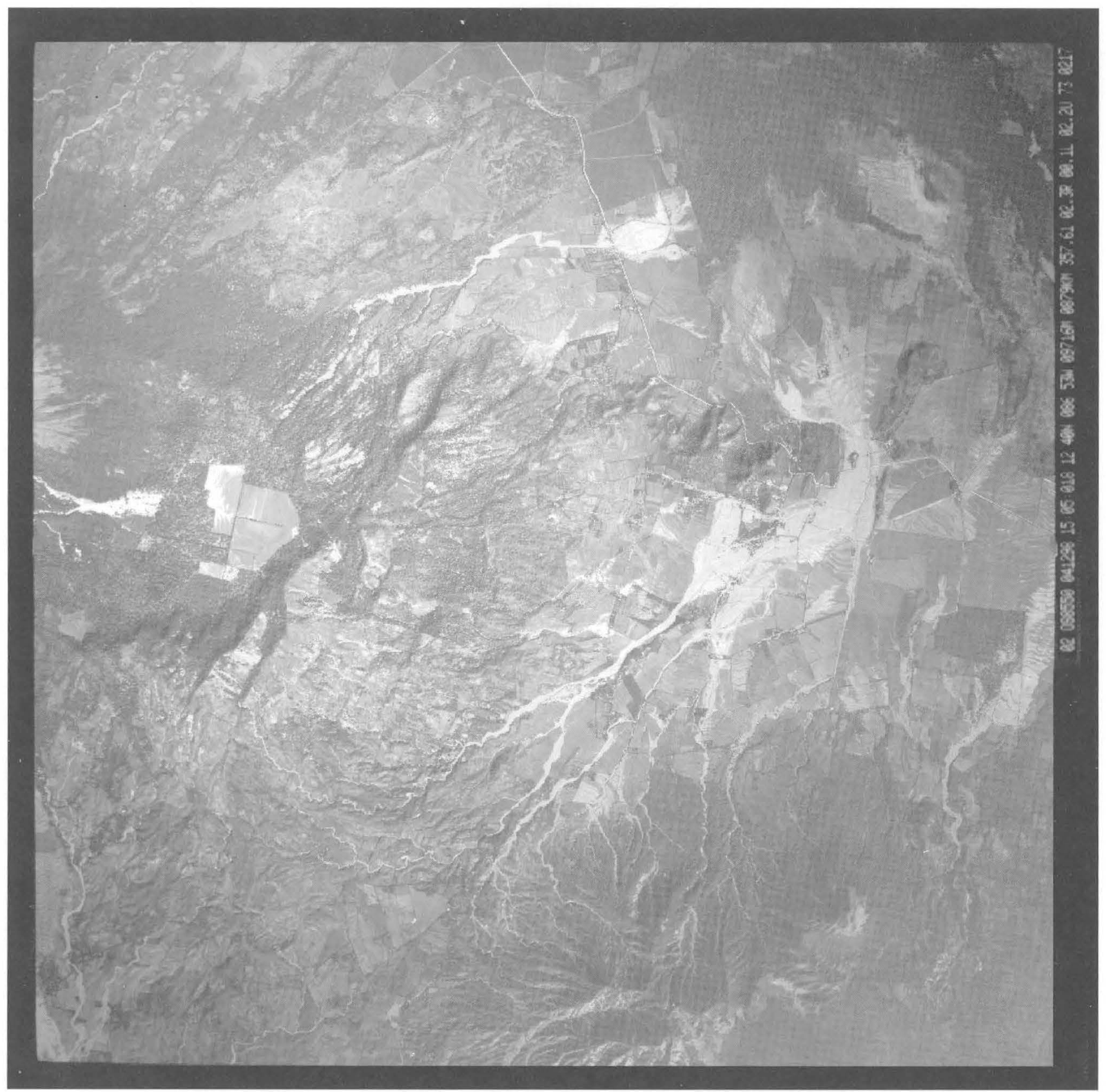

Black-and-white vertical photograph of the area east of the crater of Casita Volcano showing several large debris flows that traveled east and northeast from the eastern flank of the volcano. The northernmost flow inundated the village of El Higueral, while the larger of the debris flows traveled more than 4 miles, flowing through the village of Las Marias and west of Agua Caliente. These debris flows breached local highways in at least three locations. Many small landslides also originated on the east flank of the volcano. The debris flow at the middle right-hand margin of the photograph originated on the east flank of Telica Volcano. 


\section{Topographic map corresponding to}

\section{Frame 255-December 4, 1998-15:08:41}

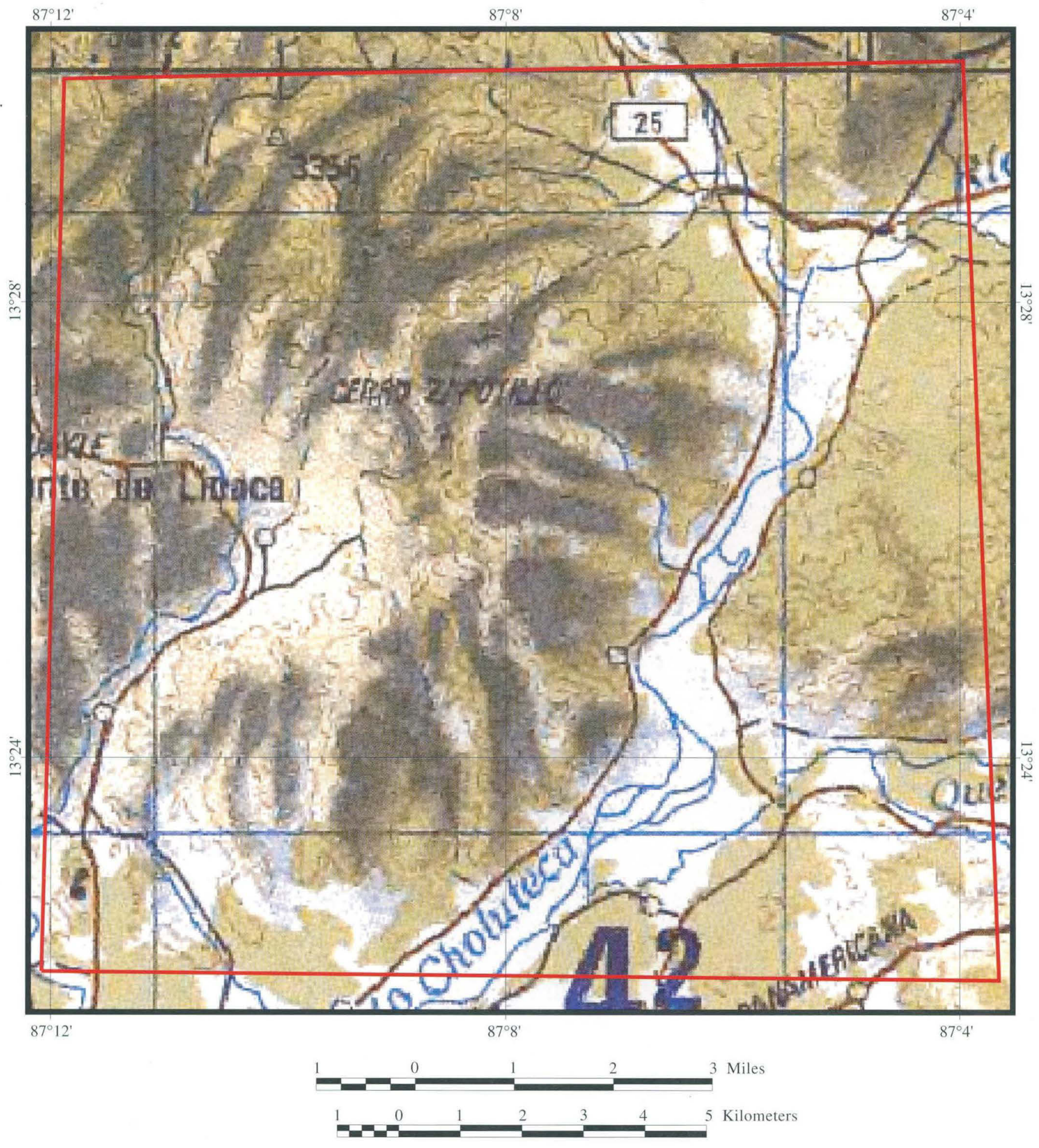

Map Source: 1:250,000-scale DMA topographic maps of Central America 


\section{Choluteca River, Honduras}

\section{Frame 255-December 4, 1998-15:08:41}

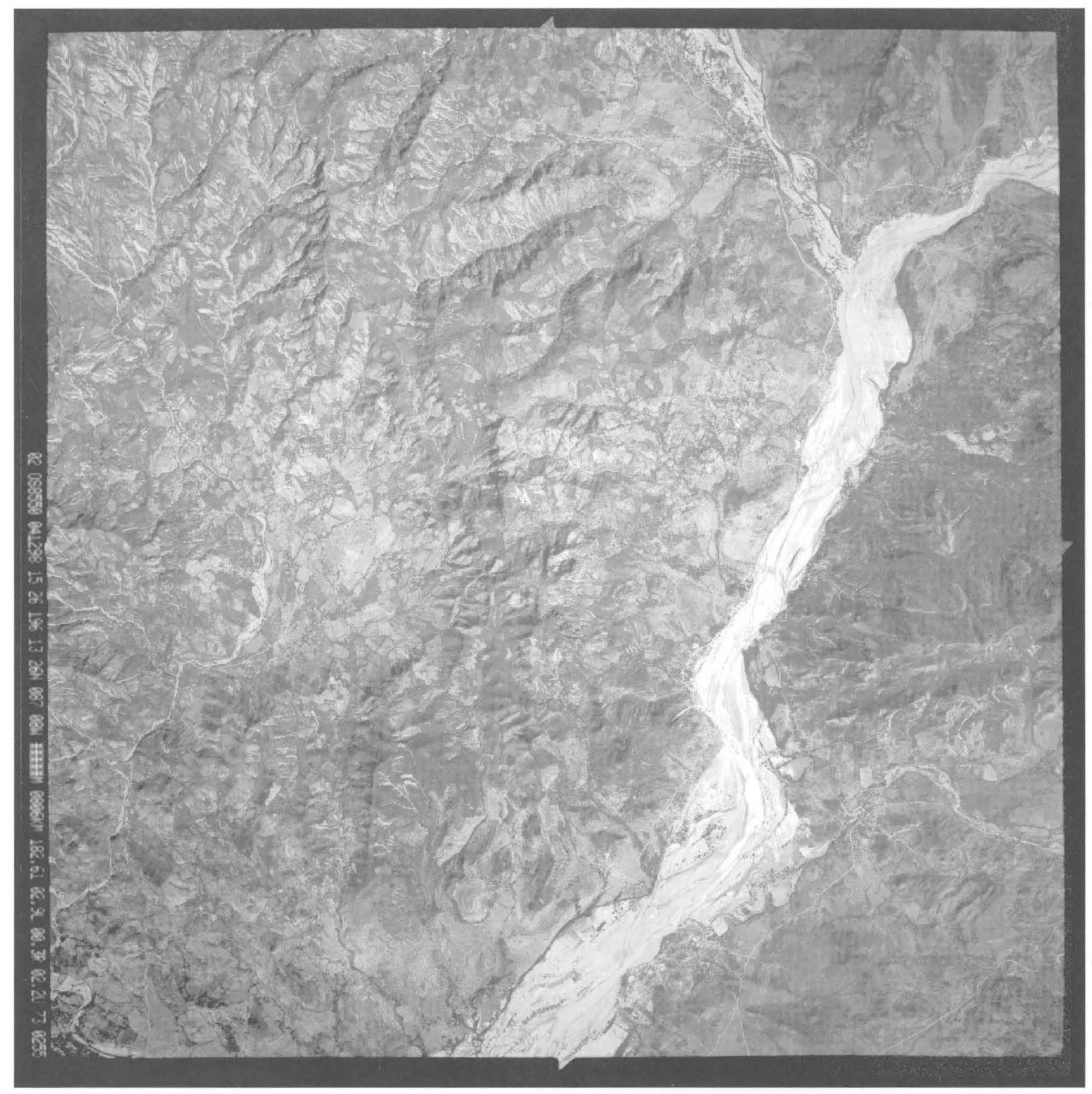

Black-and-white vertical photograph of southern Honduras, north of the city of Choluteca. Flooding deposited large quantities of sediment on the floodplain of the meandering Choluteca River. In places, the braided channel has widened to more than a mile in width. Nearly all manmade structures on the floodplain were destroyed and much of the adjacent farmland was flooded. Hundreds of small landslides cover the hillsides on both sides of the Choluteca River. More than two dozen large parallel landslides occurred west of San Antonio de Padua, the city on the west side of the large tributary that flows into the Choluteca River from the north. 


\section{Topographic map corresponding to}

Frame 257-December 4, 1998-15:27:18

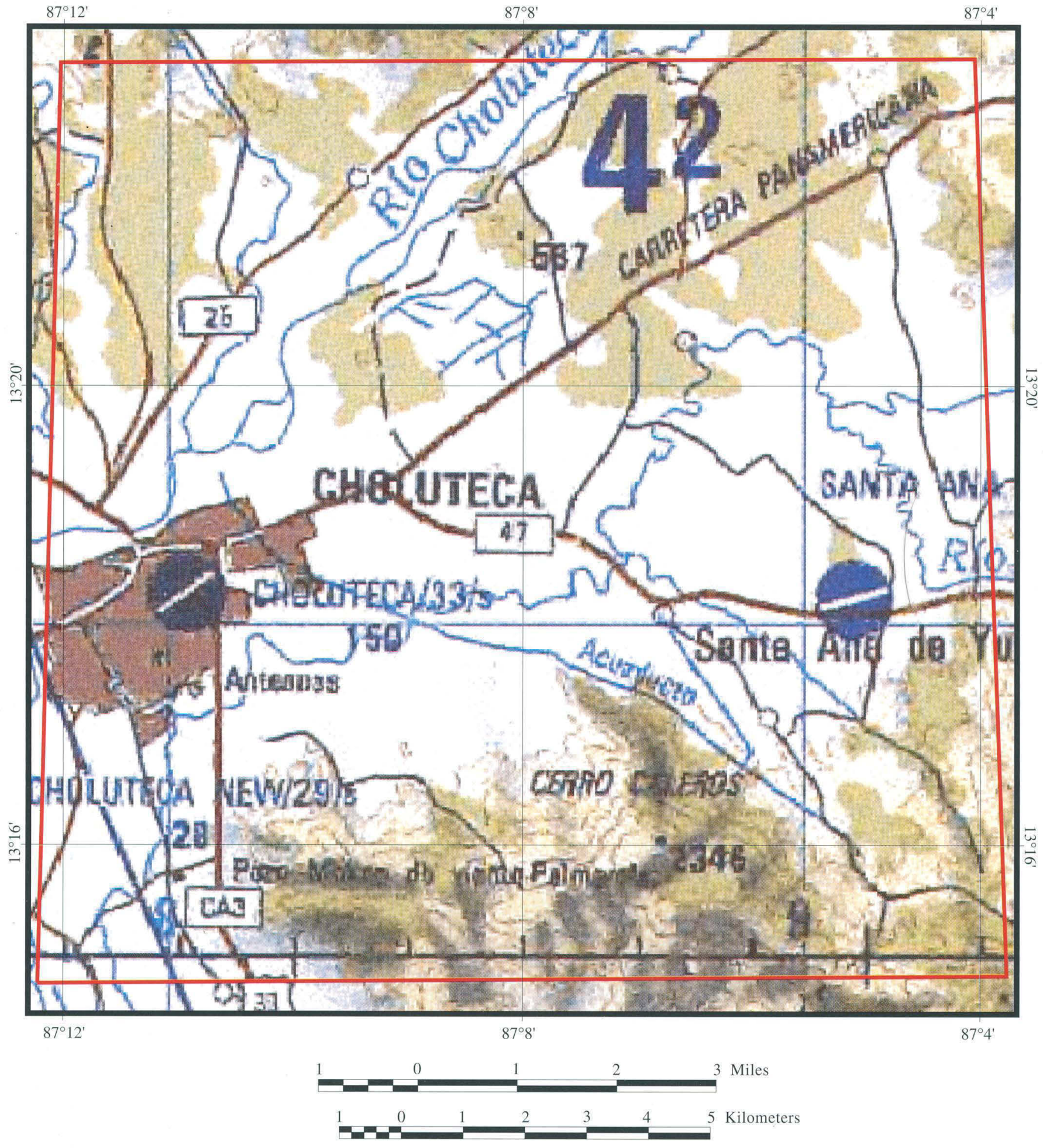

Map Source: 1:250,000-scale DMA topographic maps of Central America 


\section{Choluteca, Honduras}

\section{Frame 257-December 4, 1998-15:27:18}

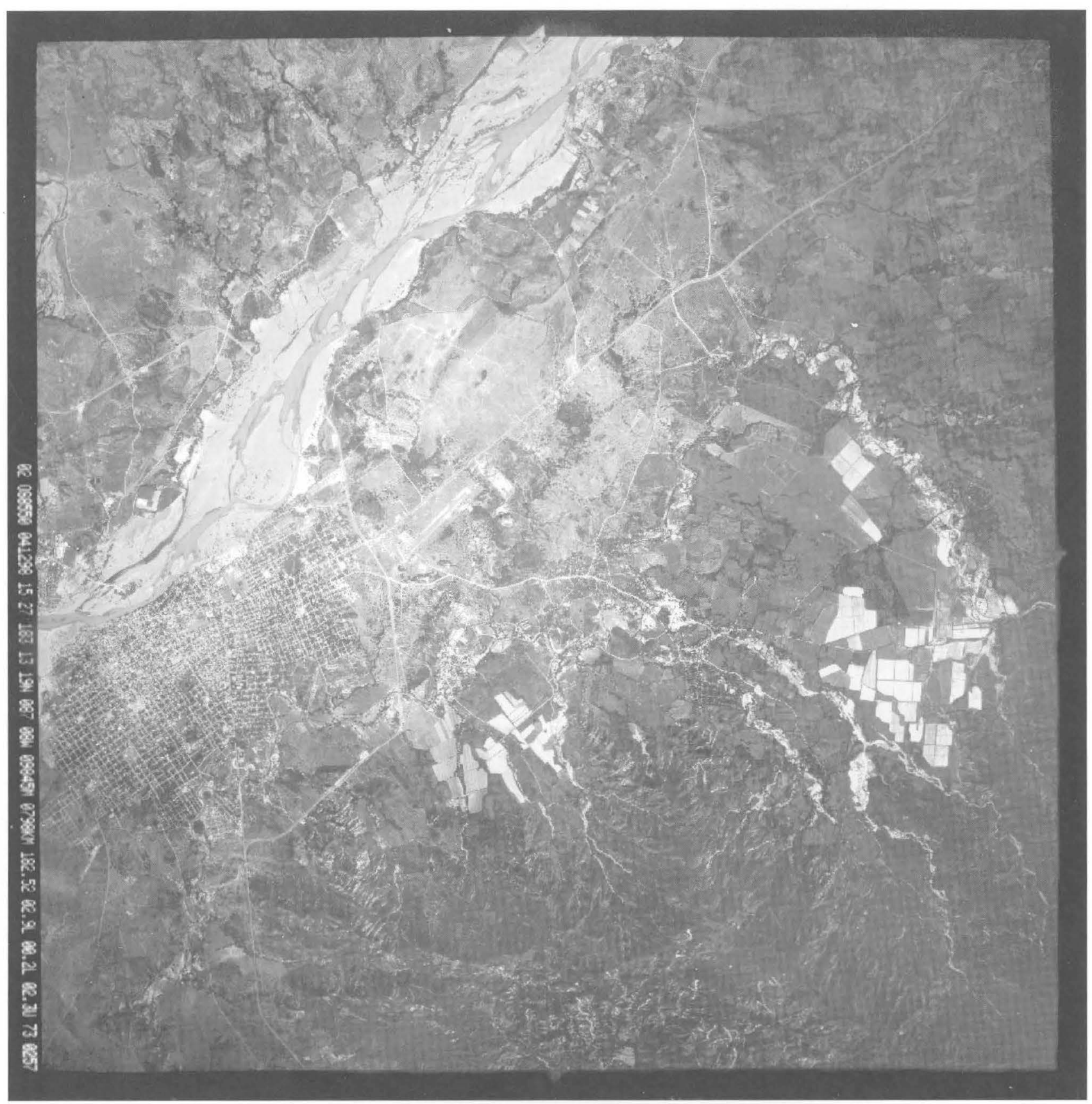

Black-and-white vertical photograph of the city of Choluteca and the Choluteca River southern Honduras. Flooding deposited large quantities of sediment in the northern part of the city and destroyed a number of neighborhoods in the city. Sediment was also deposited along the banks and on the floodplain of the Choluteca River. Nearly all manmade structures on the floodplain north of the city were destroyed, including the bridge approaches to the new crossing of the Inter-American Highway, leaving the central span of the bridge as an isolated, free-standing structure. The "old bridge" across the Choluteca River, built by the U.S. Army Corps of Engineers in the 1930's, survived the flooding, but the northern approach was destroyed when the Choluteca River temporarily changed course during the flood. 


\section{Topographic map corresponding to}

Frame 420-December 4, 1998-17:18:10

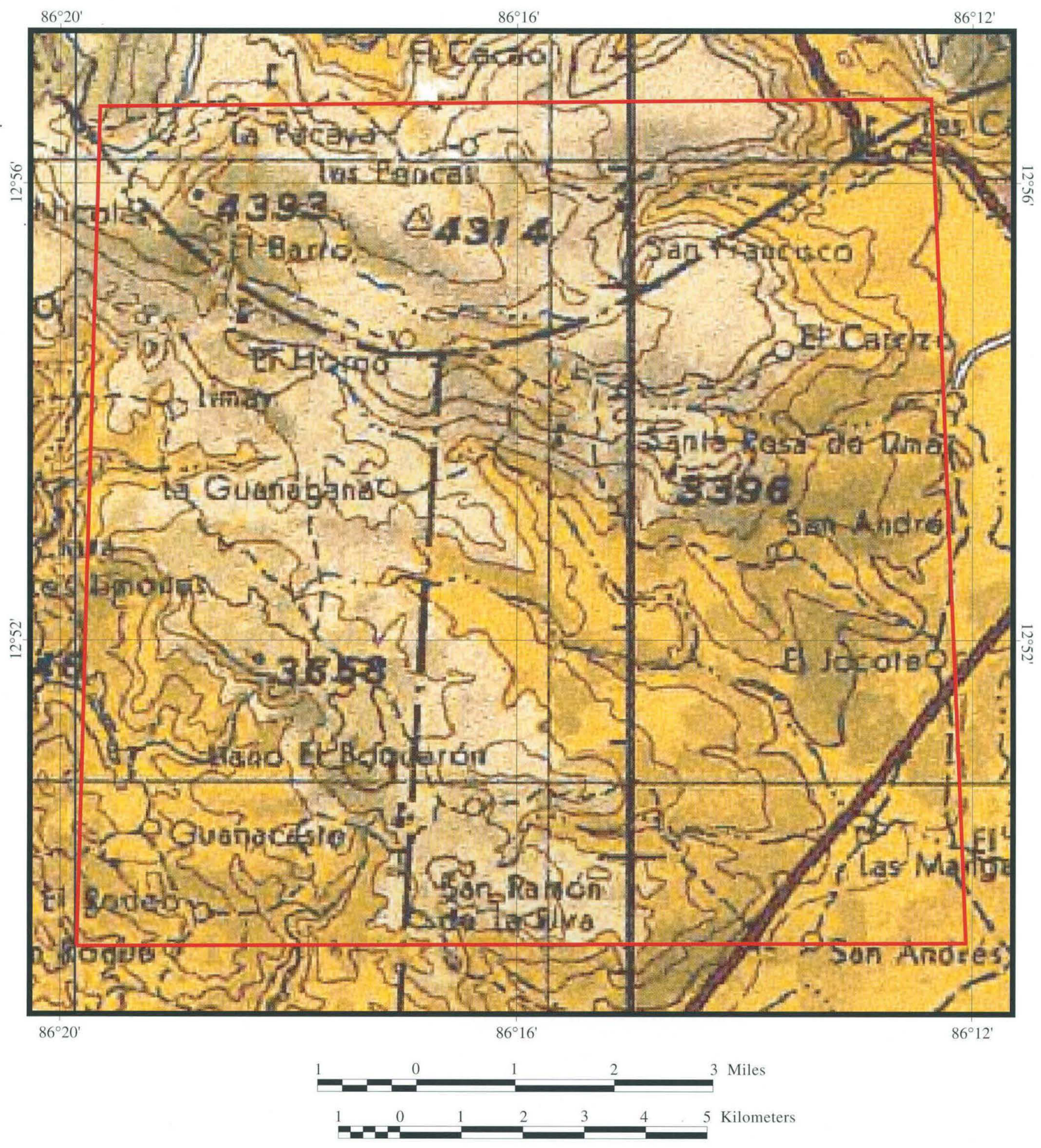

Map Source: 1:250,000-scale DMA topographic maps of Central America 


\section{North of Managua, Nicaragua}

Frame 420-December 4, 1998-17:18:10

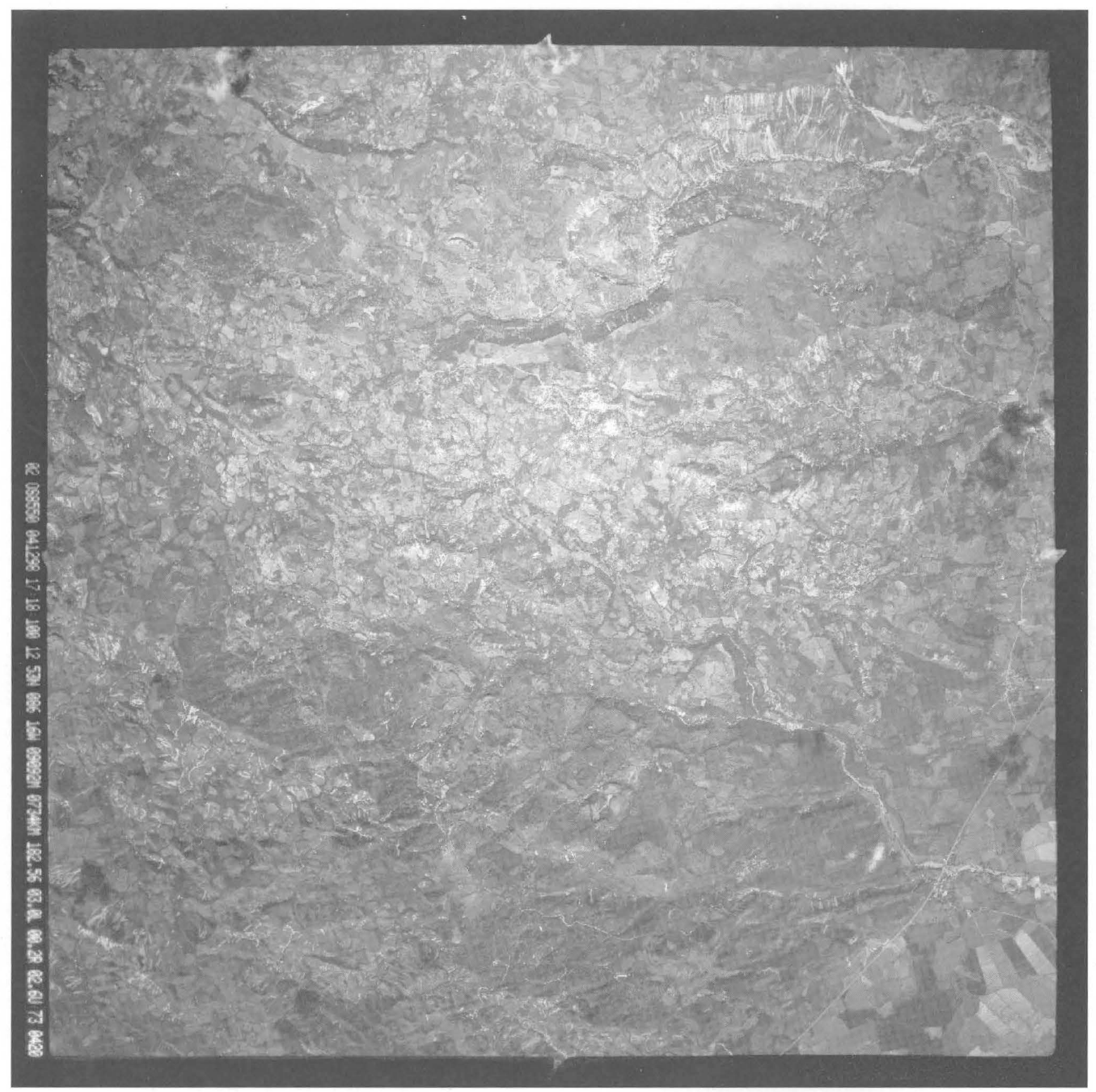

Black-and-white vertical photograph of southwestern Nicaragua, showing numerous small landslides in the upland area north of Managua. 


\section{Topographic map corresponding to \\ Frame 72-December 4, 1998-13:25:23}

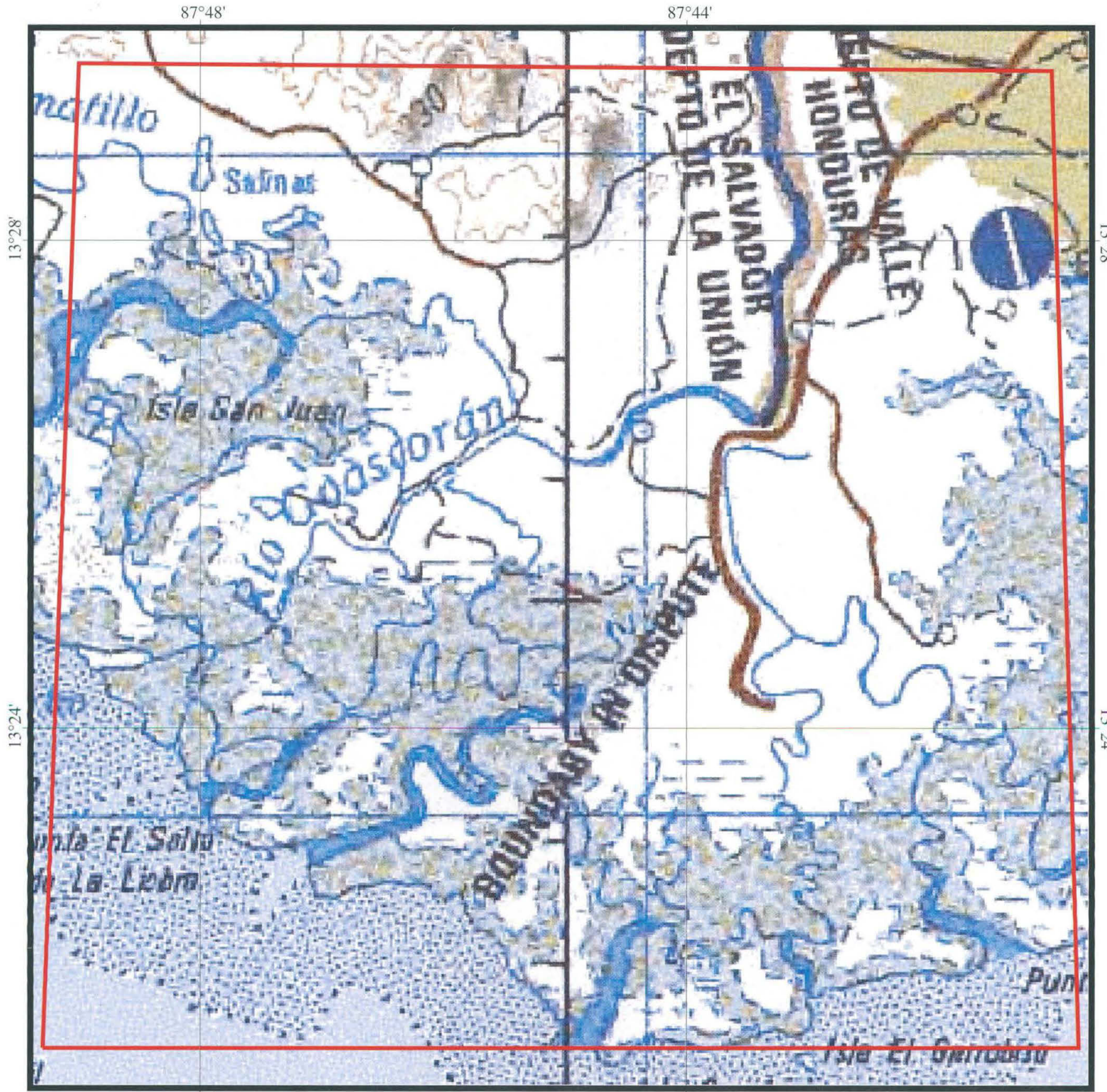

$87^{\circ} 48^{\prime}$

$87^{\circ} 44^{\prime}$

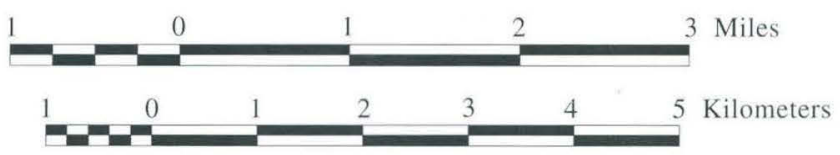

Map Source: 1:250,000-scale

DMA topographic maps of Central America 


\section{Gulf of Fonseca, El Salvador and Honduras}

Frame 72-December 4, 1998-13:25:23

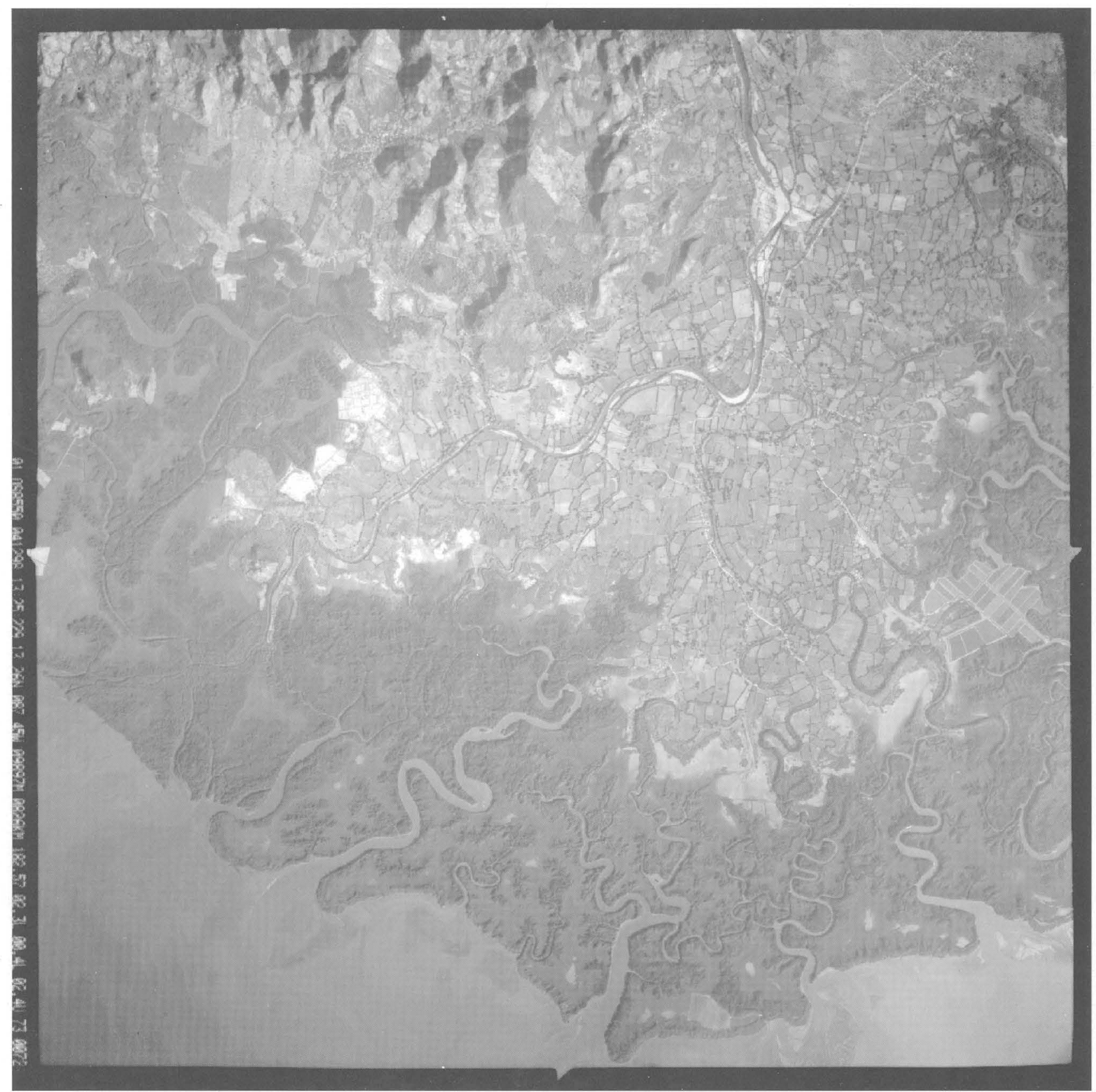

Black-and-white vertical photograph of the coastal area and mangrove wetlands along the western side of the Gulf of Fonseca, north of La Union, El Salvador, and south of Alianza, Honduras. The Rio Goascoran, which flows through the center of the photograph, marks the El Salvador-Honduras border. Most of the southern wetland area was flooded by the storm and many areas of mangroves were damaged or destroyed. Several areas still show standing water. Large quantities of sediment were deposited on agricultural fields, on the floodplain of the Rio Goascoran, and in the coastal wetlands. 


\section{Topographic map corresponding to}

Frame 94-December 4, 1998-13:42:48

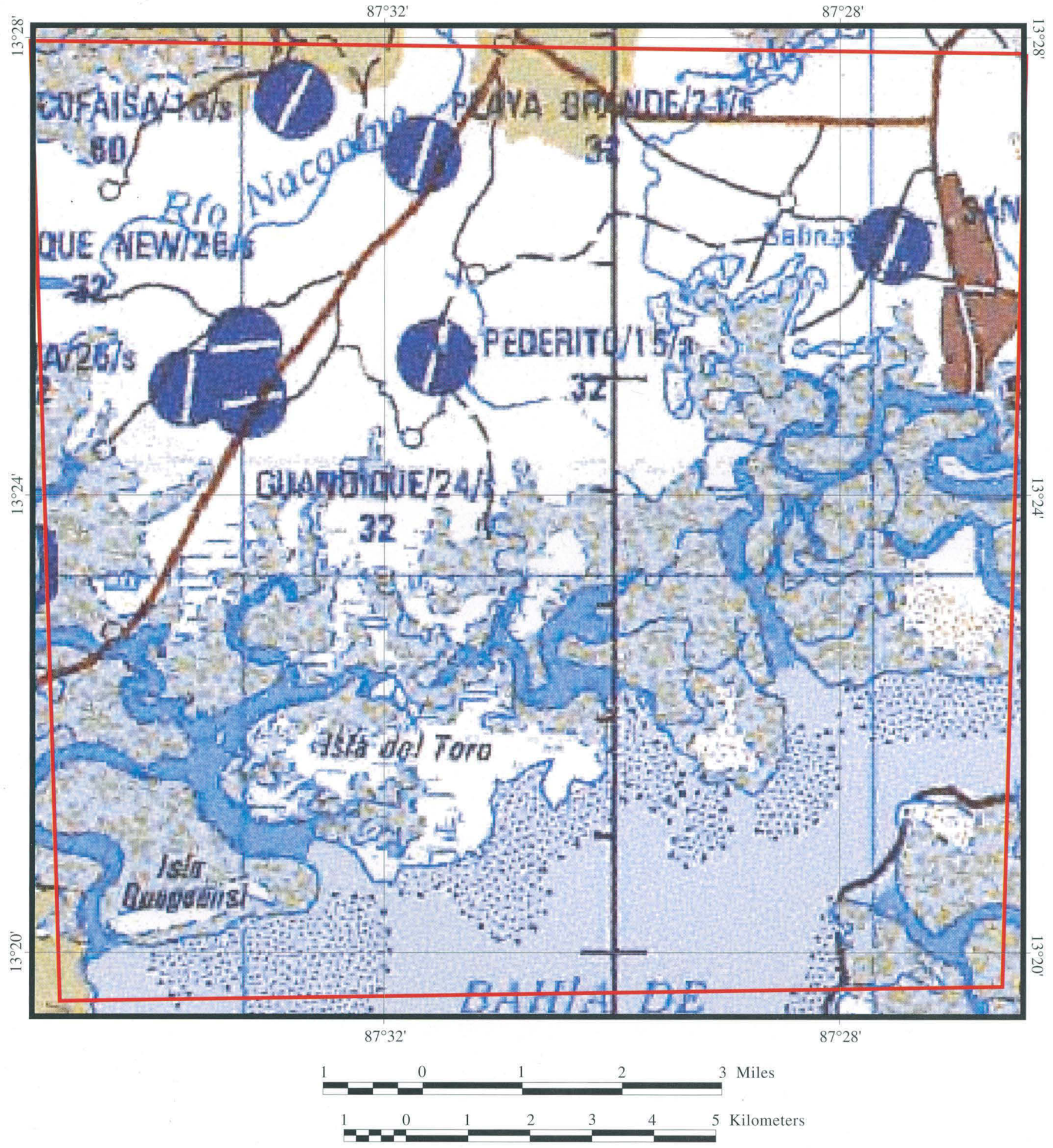

Map Source: 1:250,000-scale DMA topographic maps of Central America 


\section{Gulf of Fonseca, Honduras}

\section{Frame 94-December 4, 1998-13:42:48}

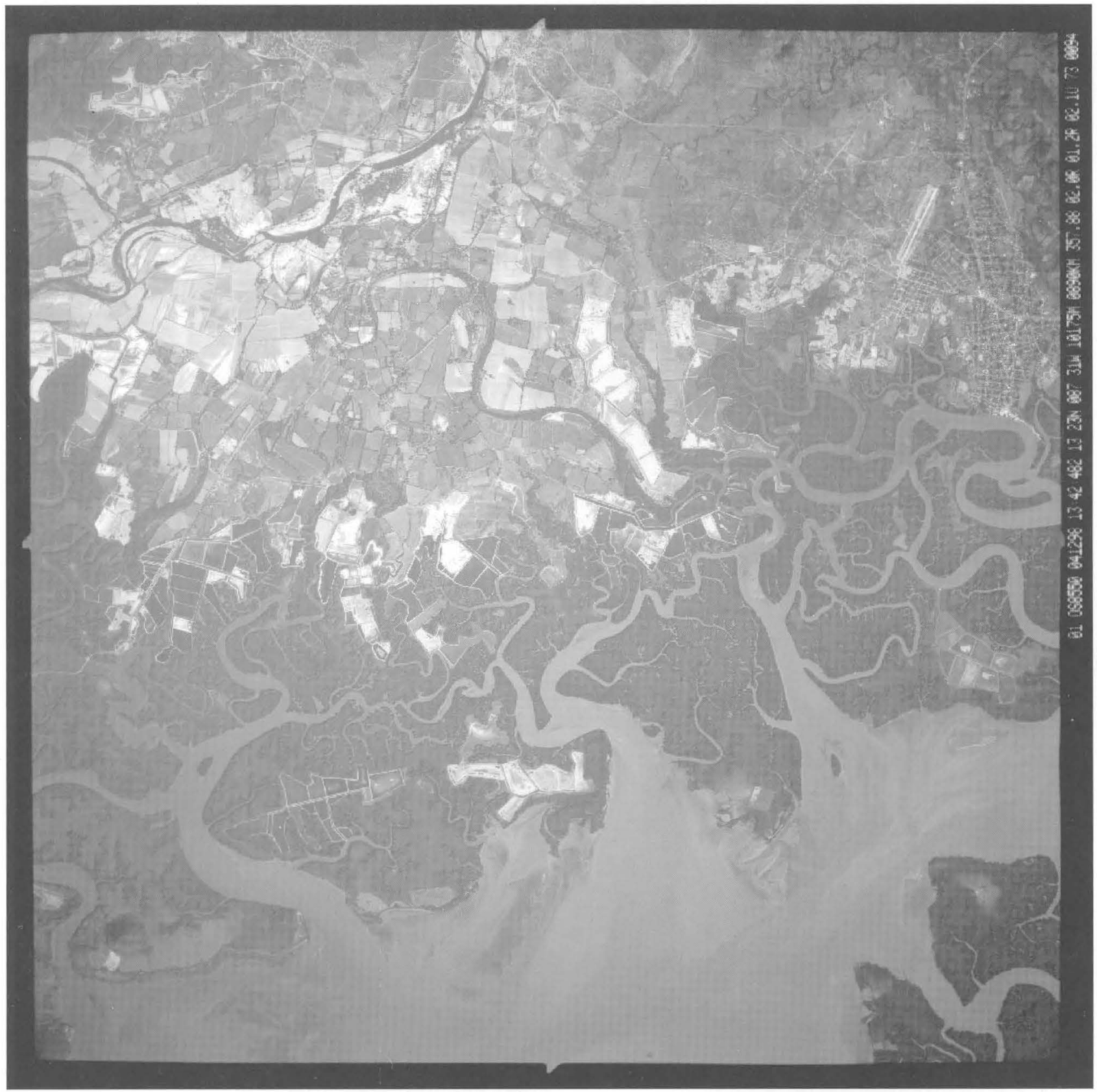

Black-and-white vertical photograph of the coastal wetlands along the northeastern side of the Gulf of Fonseca, near San Lorenzo, Honduras. The wetlands were flooded during the height of the storm and experienced significant changes in salinity. Large quantities of sediment were deposited in the diked shrimp farm ponds, on the floodplains of the Rio Nacaome, and on other coastal-plain river and estuary channels throughout the area of the photograph. 


\section{Topographic map corresponding to}

Frame 282-December 4, 1998-15:44:59

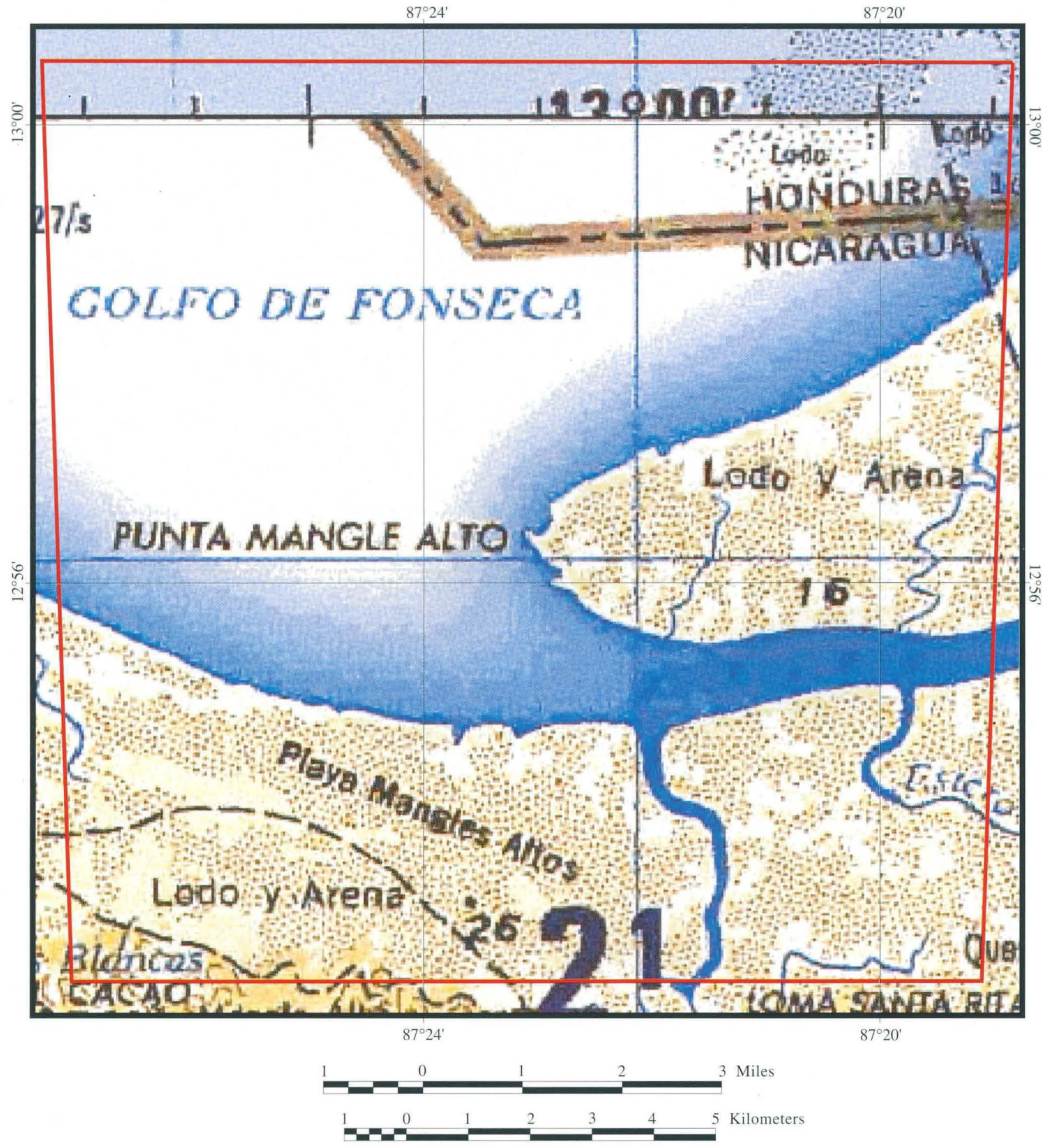

Map Source: 1:250,000-scale DMA topographic maps of Central America 


\section{Gulf of Fonseca, Nicaragua}

\section{Frame 282-December 4, 1998-15:44:59}

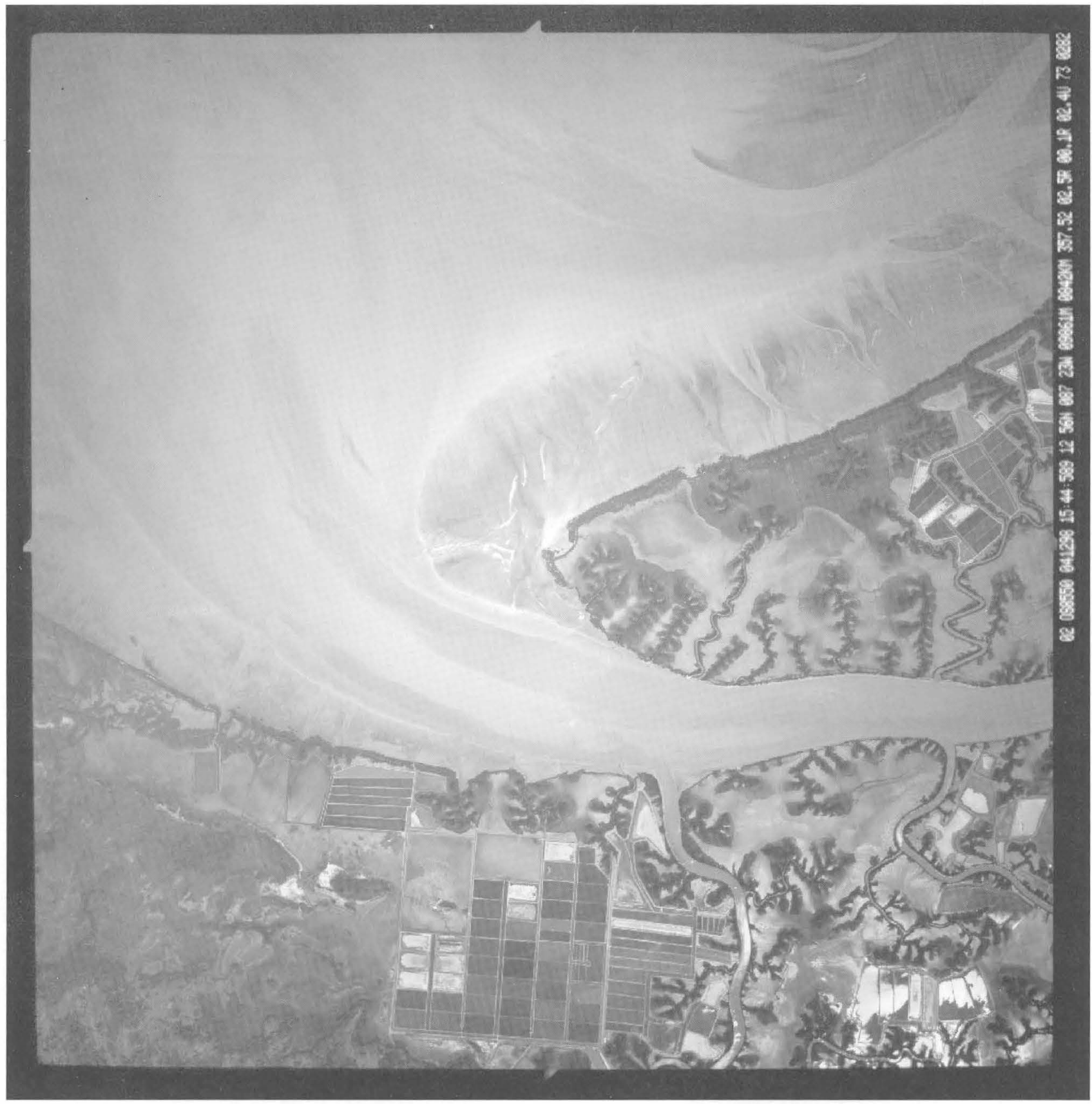

Black-and-white vertical photograph of the coastal area and wetlands along the southeastern end of the Gulf of Fonseca, west of Chinandega, Nicaragua. All of the wetland area adjacent to the Estero (Estuary) Dos Aguas Grandes was flooded during and after the storm, significantly affecting the numerous shrimp farms located to the south and east. Several areas still show standing water. Large quantities of sediment were deposited in many wetland channels and on the banks of the southern coastal-plain rivers. 


\section{Topographic map corresponding to}

\section{Frame 125-December 4, 1998-14:07:01}

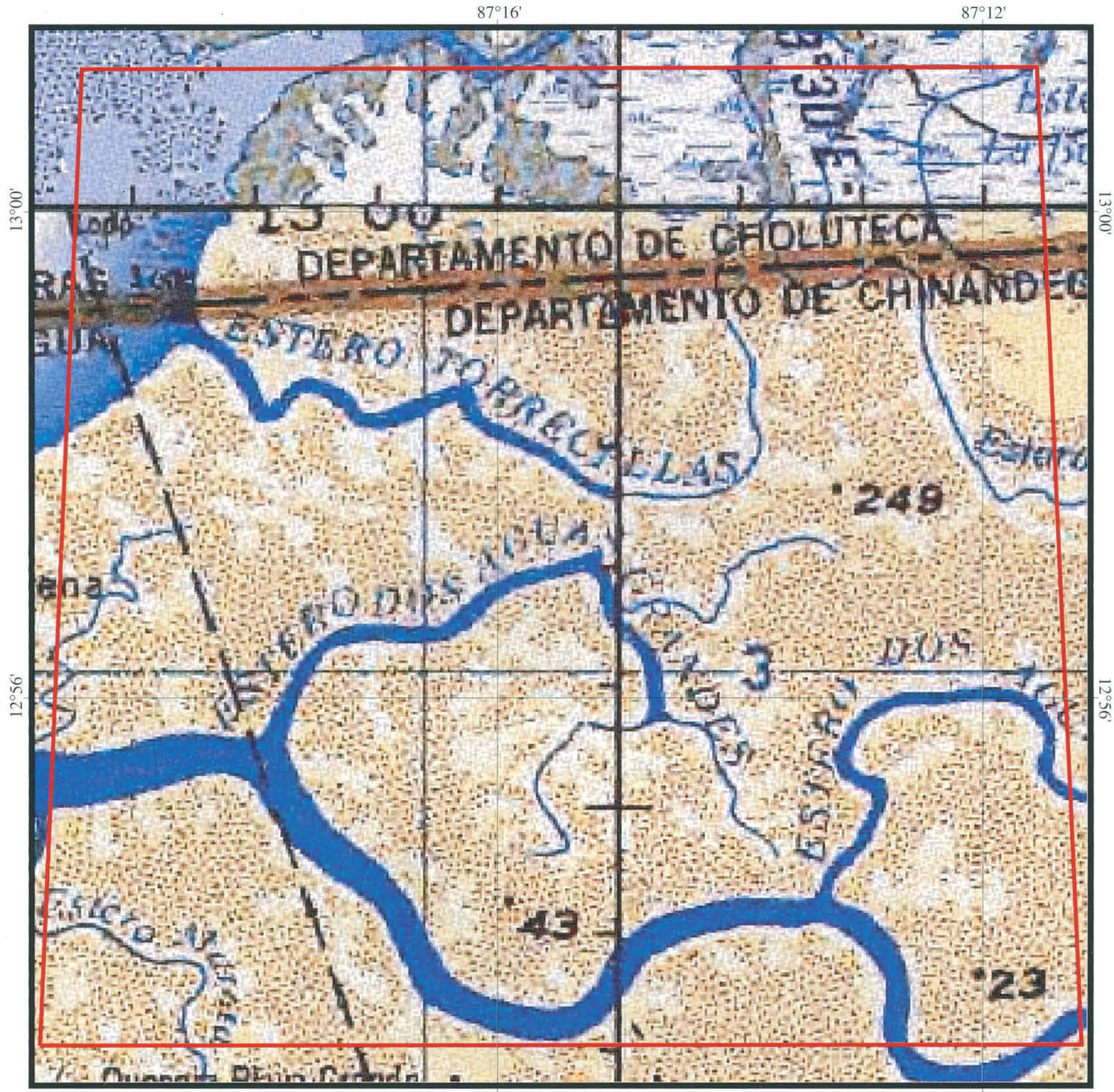

$87^{\circ} 16^{\prime}$

$87^{\circ} 12^{\prime}$

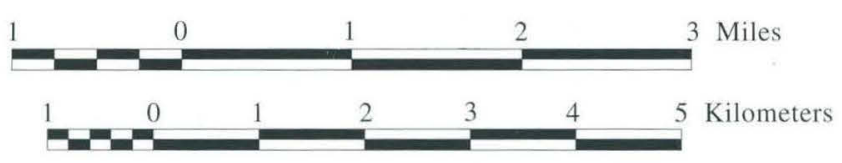

Map Source: 1:250,000-scale DMA topographic maps of Central America 


\section{Gulf of Fonseca, Honduras and Nicaragua}

\section{Frame 125-December 4, 1998-14:07:01}

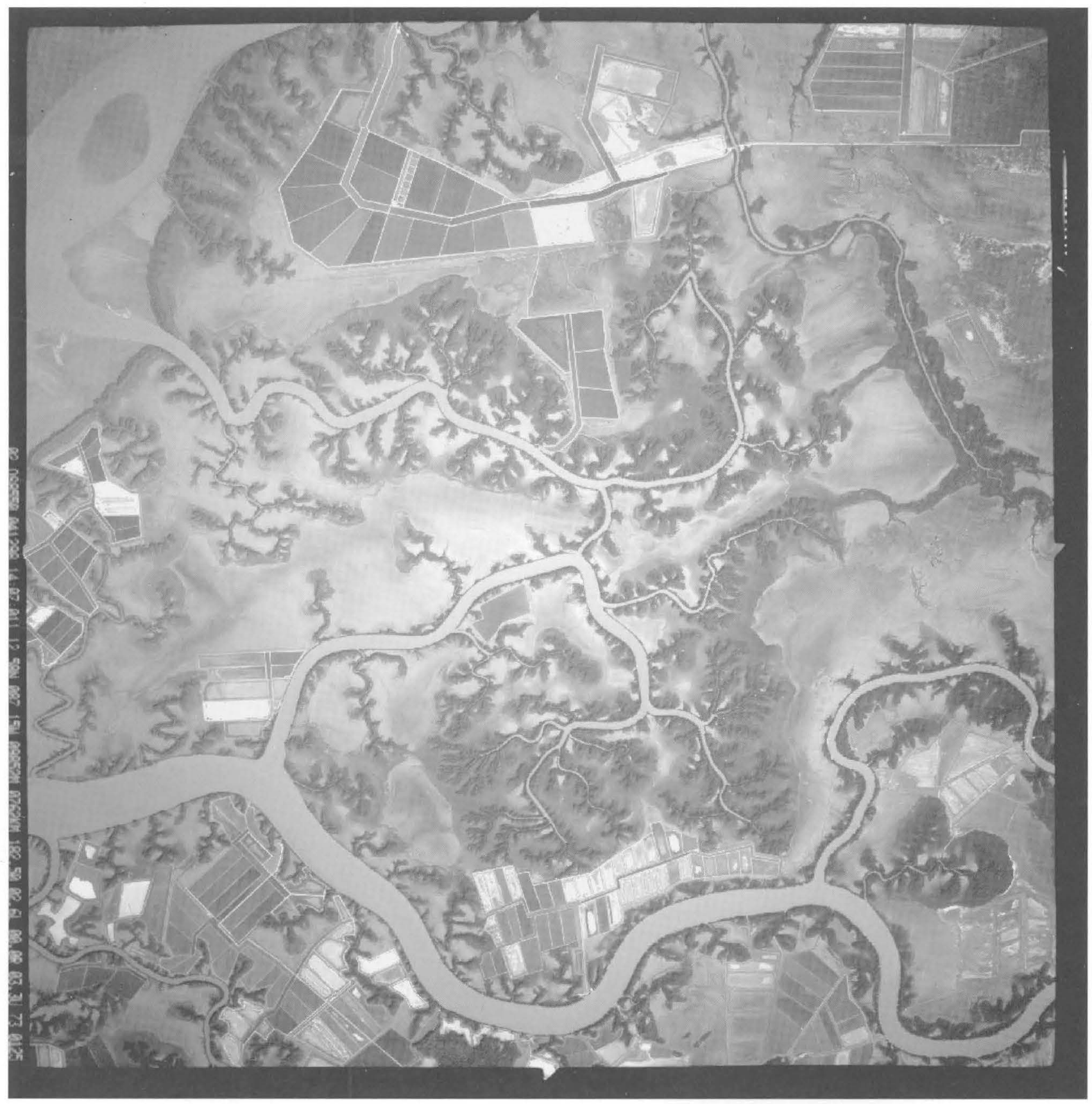

Black-and-white vertical photograph of the coastal area and wetlands along the eastern side of the Gulf of Fonseca, along the Honduras-Nicaragua border, north of Chinandega. Much of the wetland area included diked shrimp farms and agricultural areas that were flooded during and after the storm. Many of the shrimp farms had dikes that breached, causing significant changes in salinity. Several areas still show standing water. Large quantities of sediment were deposited in many wetland channels 


\section{Topographic map corresponding to}

Frame 85-December 4, 1998-13:38:15

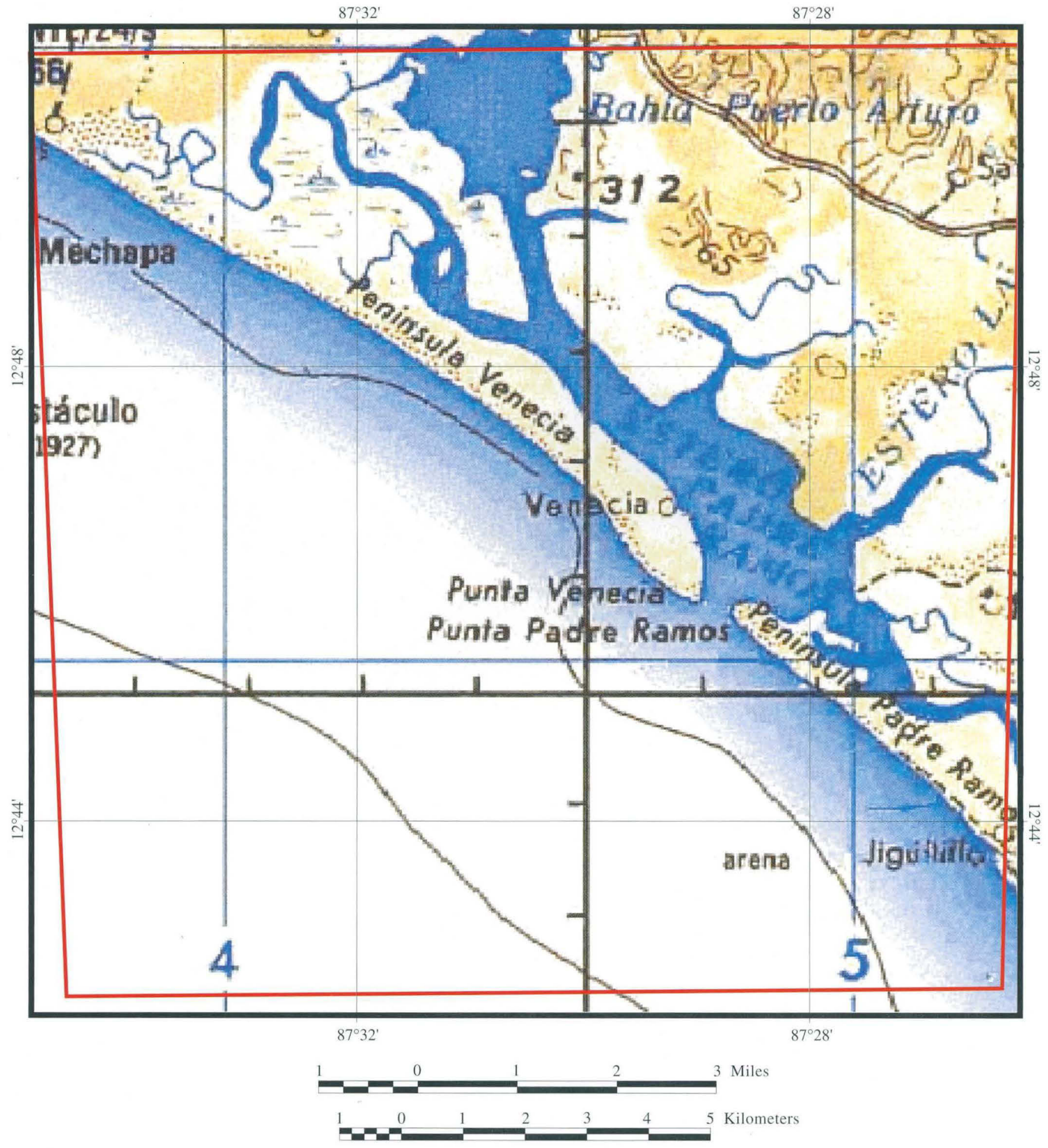

Map Source: 1:250,000-scale DMA topographic maps of Central America 


\section{Estero Padre Ramos, Nicaragua}

Frame 85-December 4, 1998-13:38:15

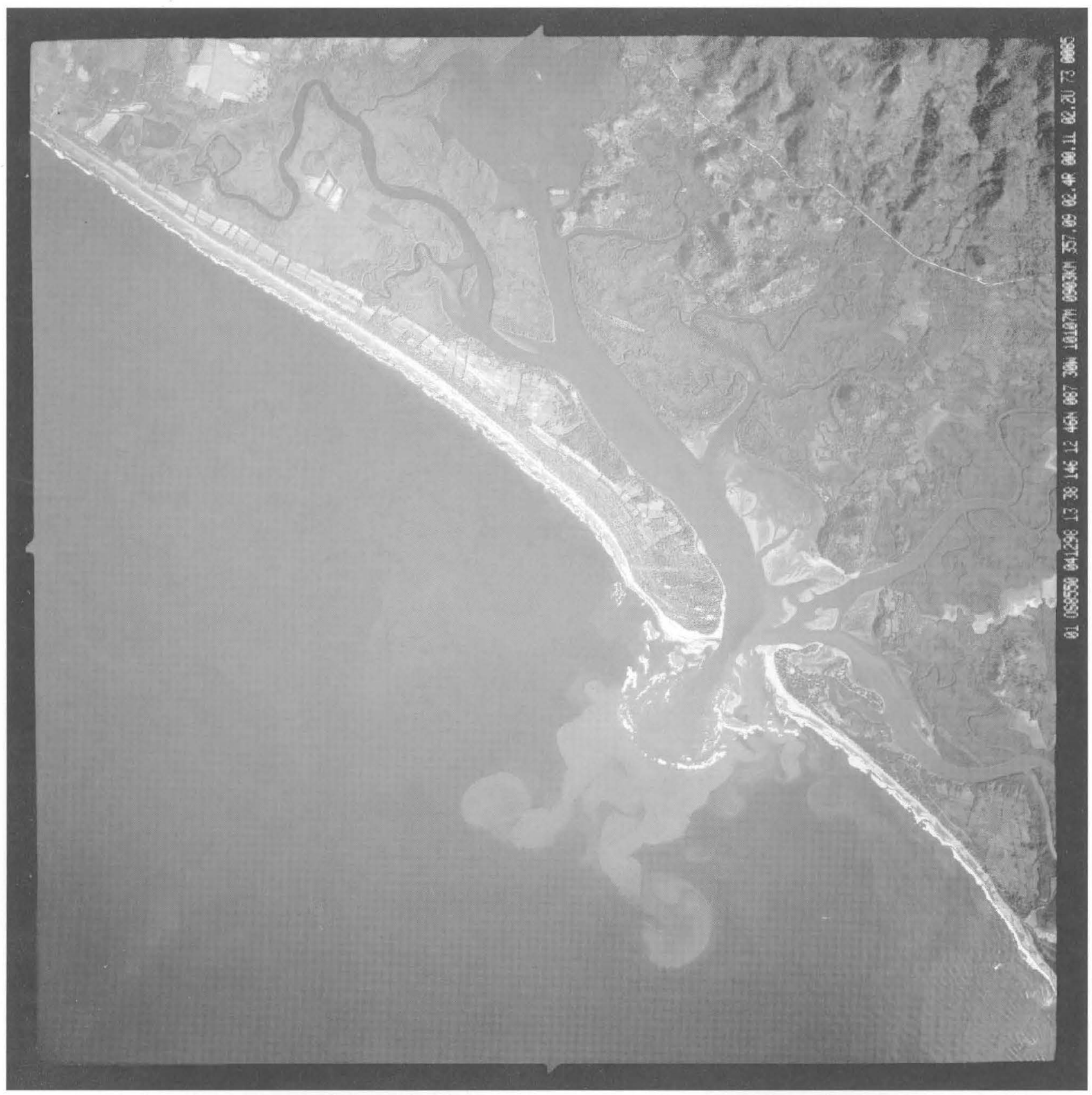

Black-and-white vertical photograph of the Pacific Ocean coastal area and wetlands at the Estero (Estuary) Padre Ramos northwest of Jiguililo, Nicaragua. Sediment deposited at the mouth of the estuary has contributed to building a large delta, nearly blocking the inlet and creating a hazard to navigation. Other Pacific Ocean estuary and river mouths show similar sedimentation. Although this photograph was made 5 weeks after the storm, a large quantity of suspended sediment is still flowing into the Pacific Ocean as a plume. Much of the wetland area was flooded. Several areas still show standing water, and large quantities of sediment were deposited in many wetland channels. Frame 347 is a color image of the same area. 


\section{Topographic map corresponding to}

Frame 347-December 4, 1998-16:29:50

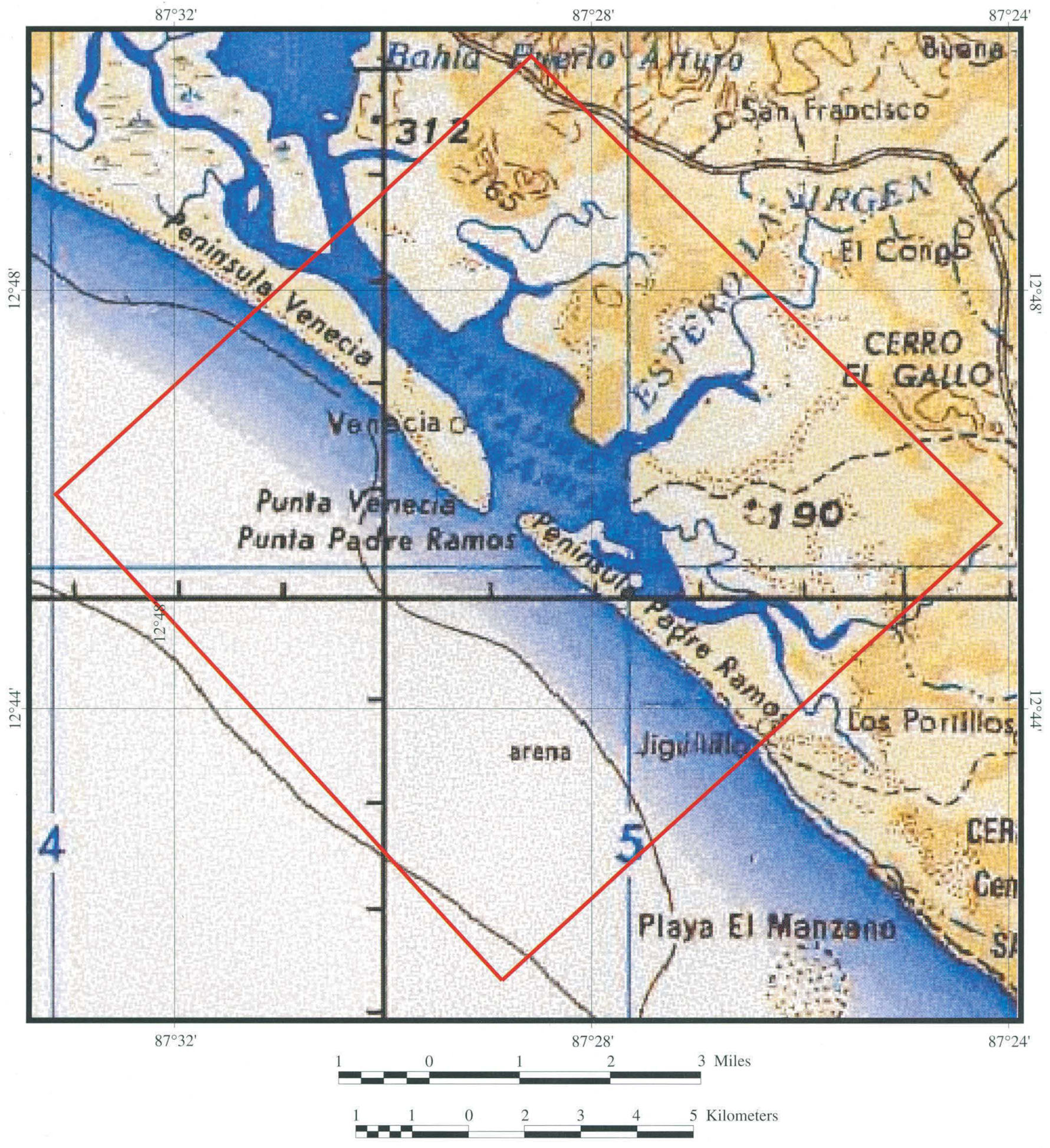

Map Source: 1:250,000-scale

DMA topographic maps of Central America 


\section{Estero Padre Ramos, Nicaragua}

\section{Frame 347-December 4, 1998-16:29:50}

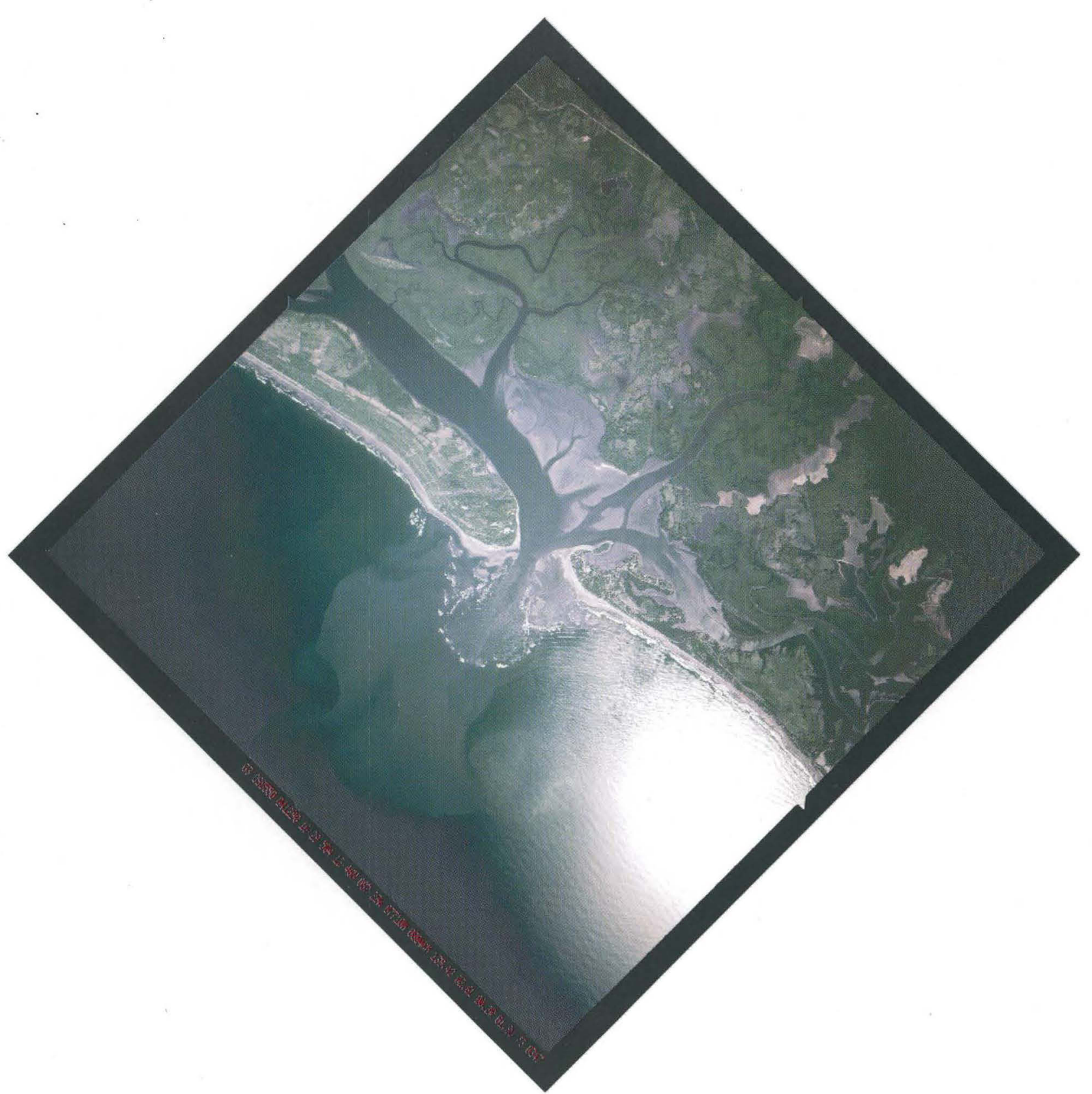

Color vertical photograph of the Pacific Ocean coastal area and wetlands at the Estero (Estuary) Padre Ramos northwest of Jiguililo, Nicaragua. Sediment deposited at the mouth of the estuary has contributed to building a large delta, nearly blocking the inlet and creating a hazard to navigation. Other Pacific Ocean mouths show similar sedimentation. Although this photograph was made 5 weeks after the storm, a large quantity of suspended sediment is still flowing into the Pacific Ocean as a plume. Much of the wetland area was flooded. Several areas still show standing water, and large quantities of sediment were deposited in many wetland channels. Frame 85 is a black-and-white image of the same area. 


\section{Topographic map corresponding to}

Frame 427-December 4, 1998-17:21:49

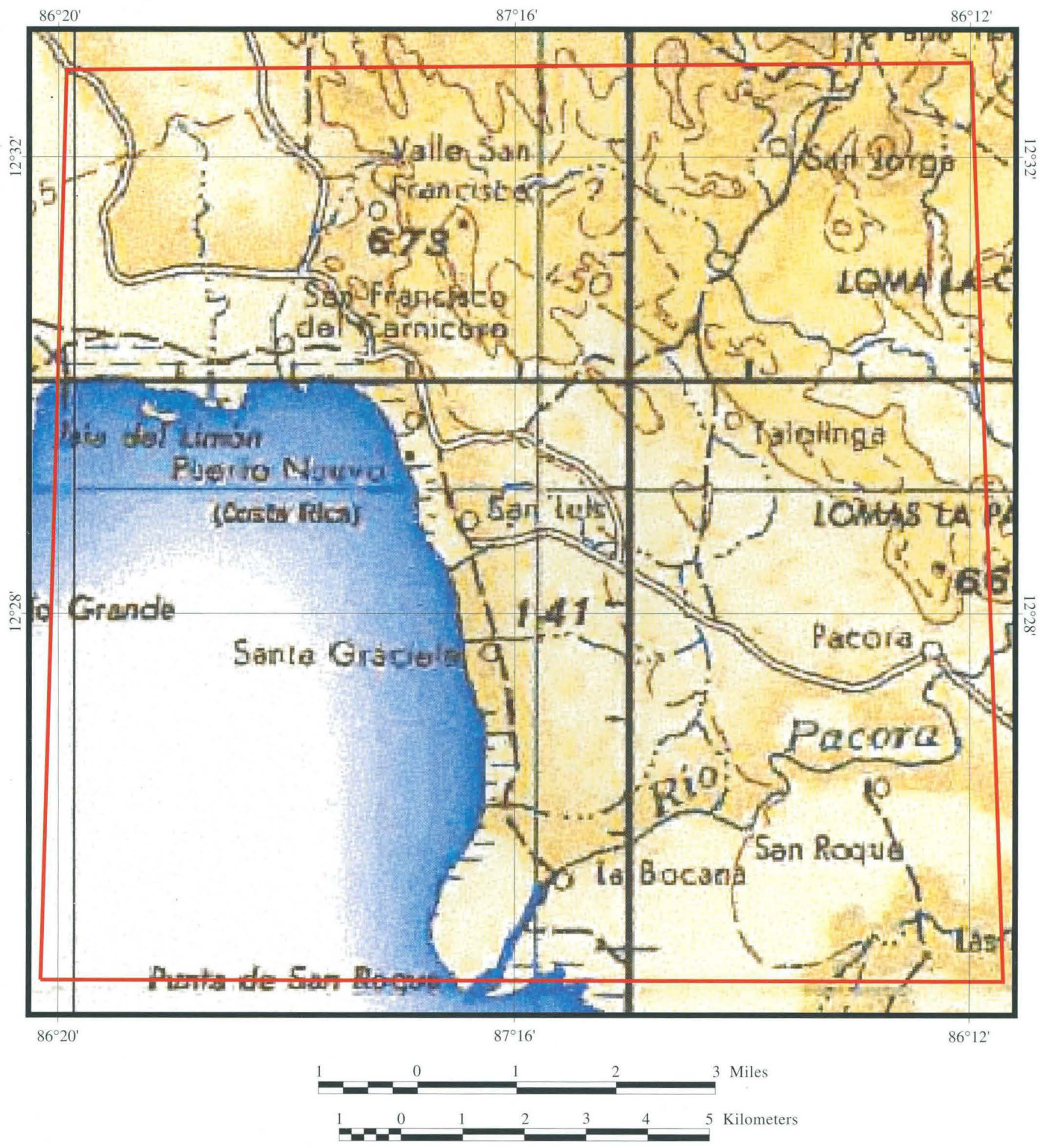

Map Source: 1:250,000-scale DMA topographic maps of Central America 


\section{Lago de Managua, Nicaragua}

Frame 427-December 4, 1998-17:21:49

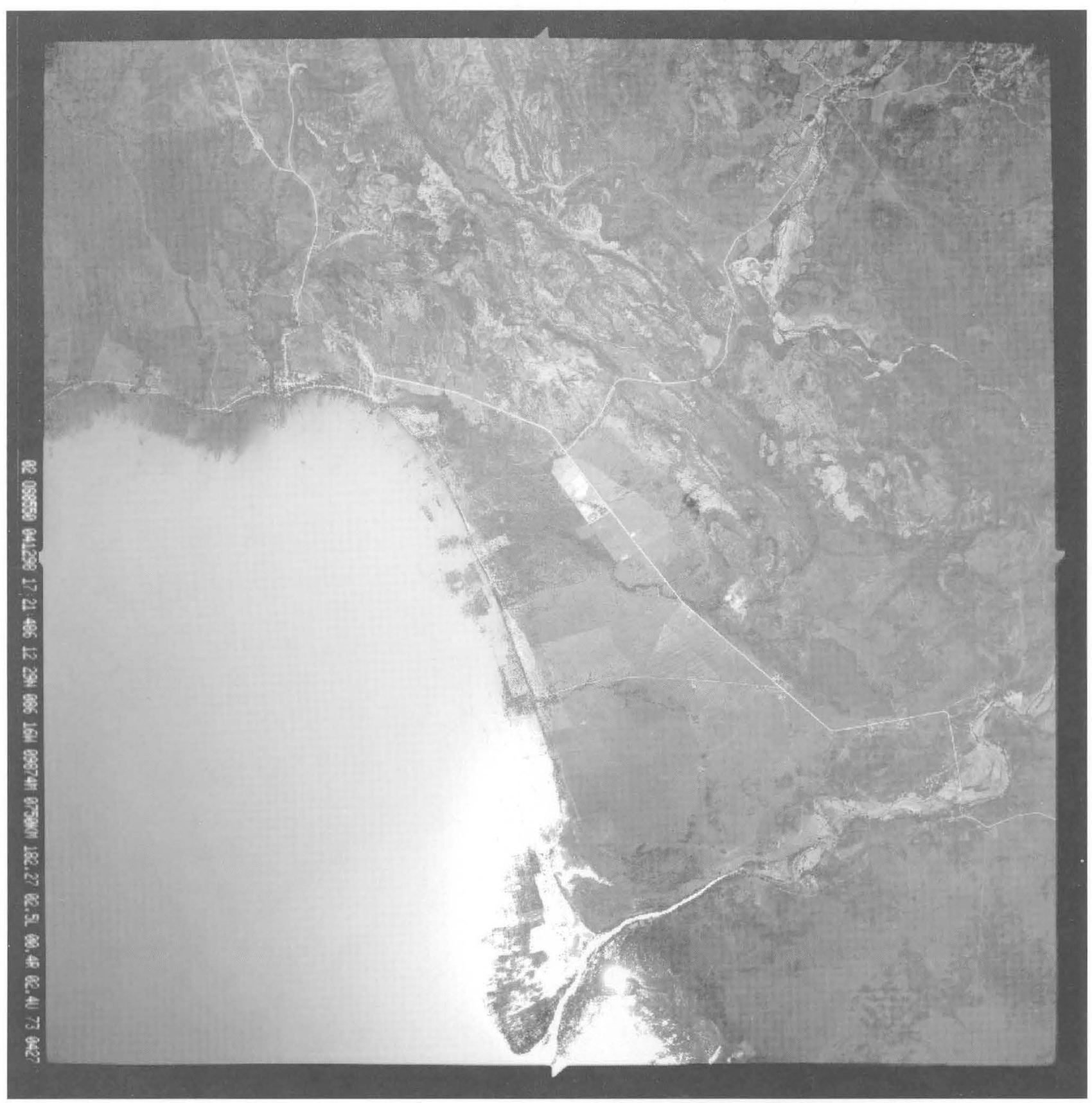

Black-and-white vertical photograph of southwestern Nicaragua, showing flooding along the shoreline and the high water level in Lago de Managua, northwest of Managua. Five weeks after the storm, numerous farms and settlements were still under water. The level in this large lake rose about 15 feet. 


\section{Topographic map corresponding to \\ Frame 205-December 4, 1998-14:52:46}

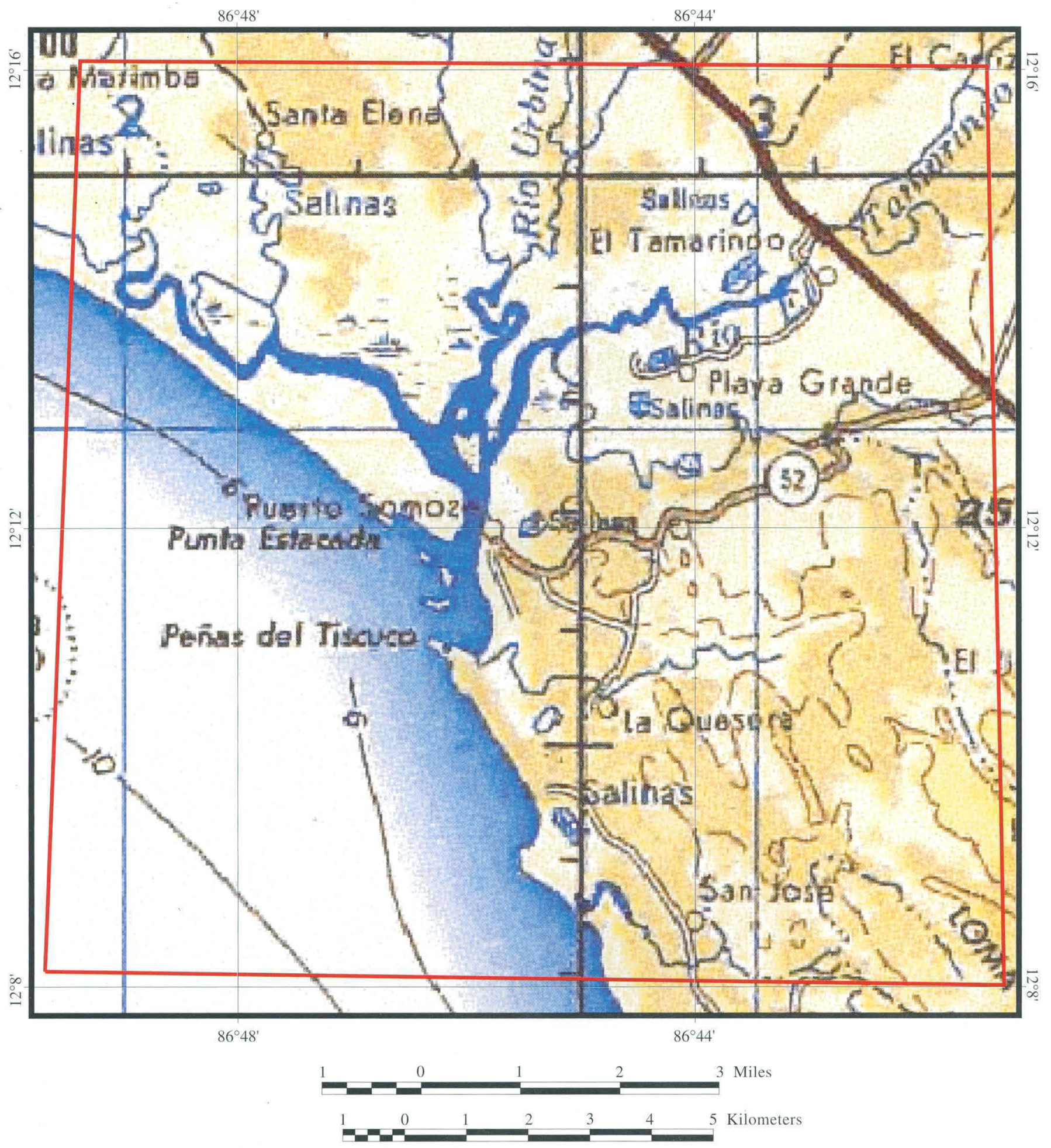

Map Source: 1:250,000-scale DMA topographic maps of Central America 


\section{Estero Aposentillo, Nicaragua}

\section{Frame 271-December 4, 1998-15:34:29}

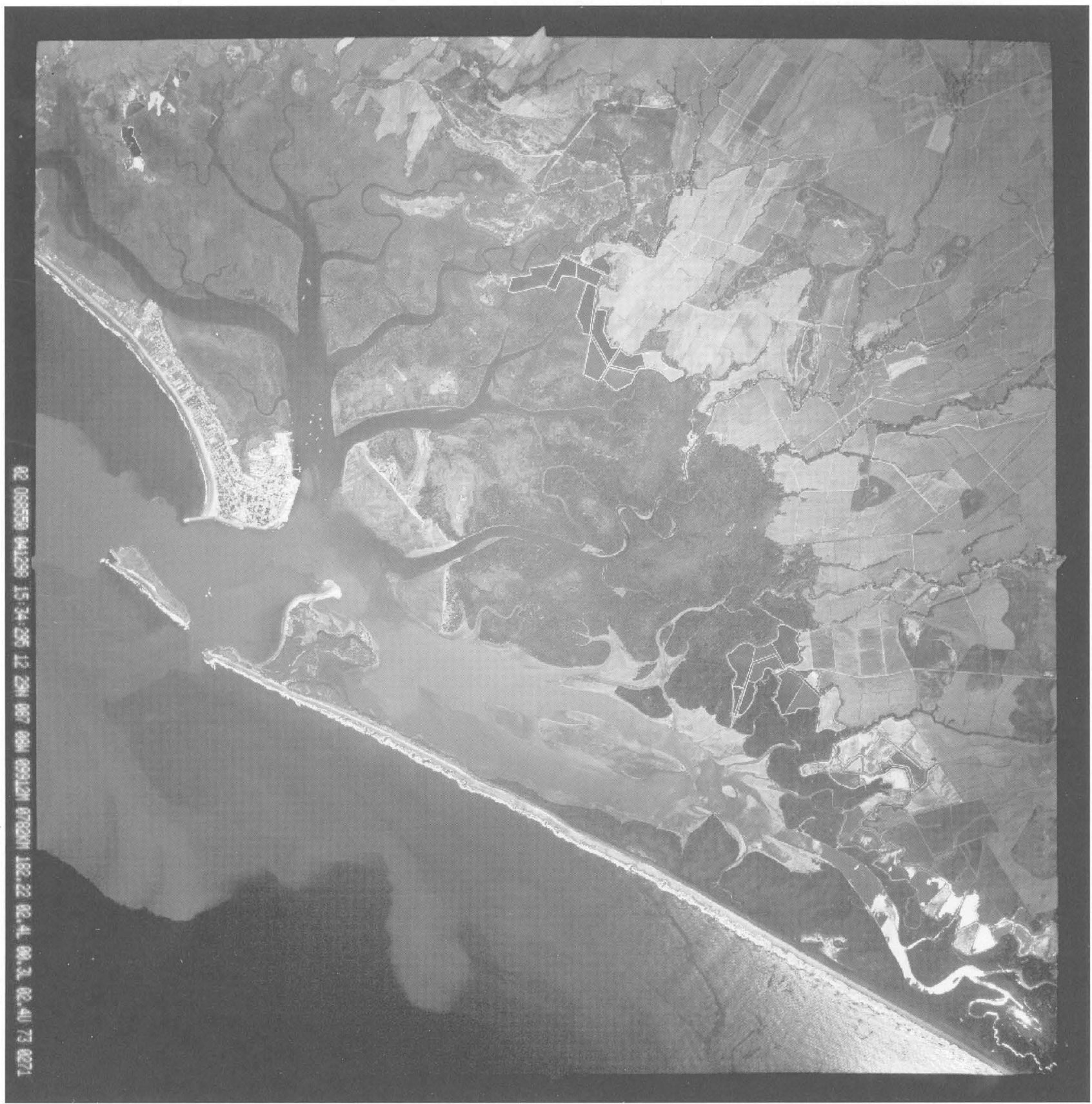

Black-and-white vertical photograph of the Pacific Ocean coastal area and wetlands at the Estero (Estuary) Aposentillo southwest of Chinandega, Nicaragua. Although this photograph was made 5 weeks after the storm, a large quantity of suspended sediment is still flowing into the Pacific Ocean as a distinct plume. All of the wetland area behind the coastal barrier islands was flooded following the storm. Several areas still show standing water. Large quantities of sediment were deposited in the wetland channels and in some of the diked ponds. 


\section{Topographic map corresponding to}

Frame 205-December 4, 1998-14:52:46

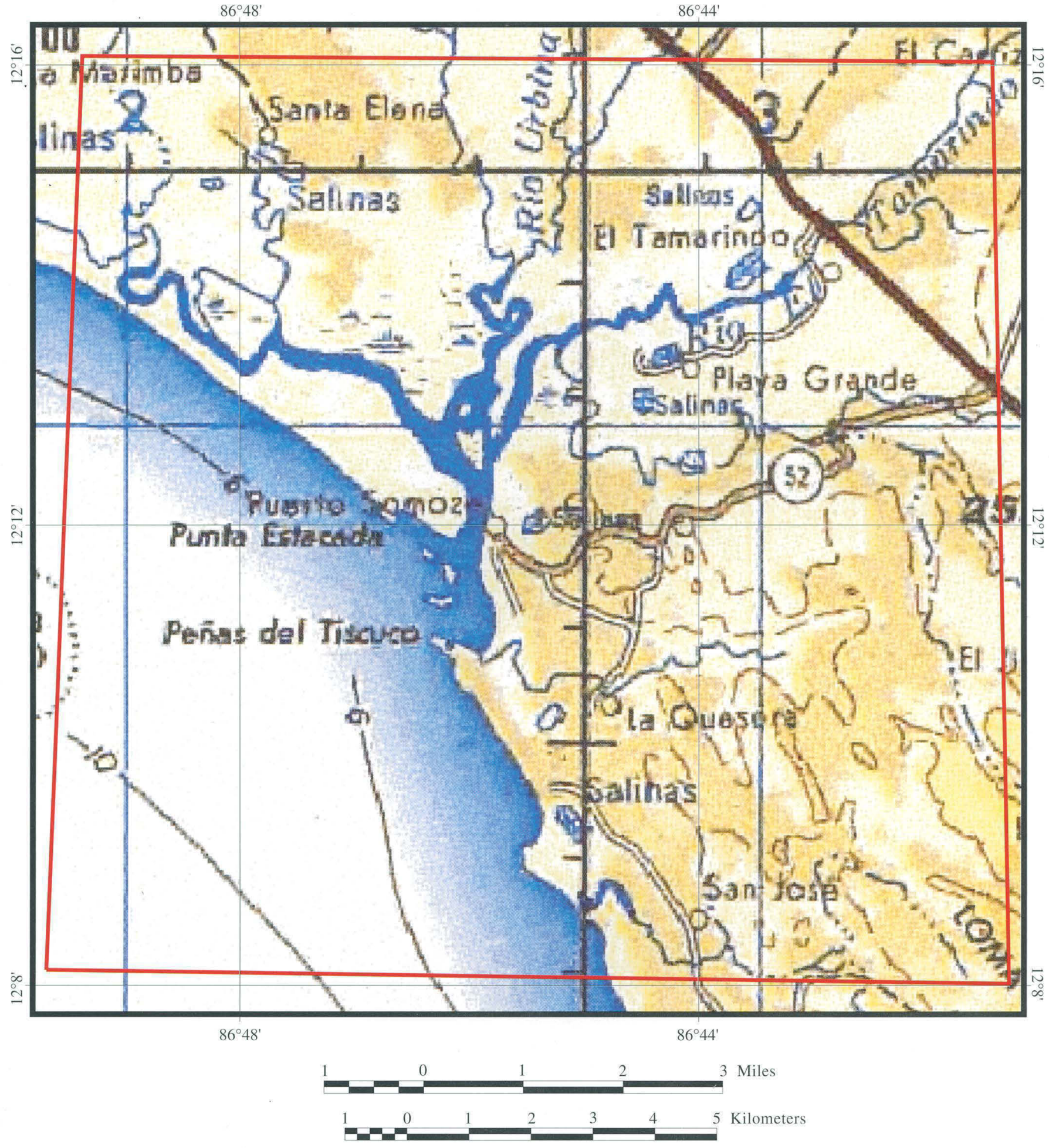

Map Source: 1:250,000-scale DMA topographic maps of Central America 


\section{El Tamarindo,Nicaragua}

\section{Frame 205-December 4, 1998-14:52:46}

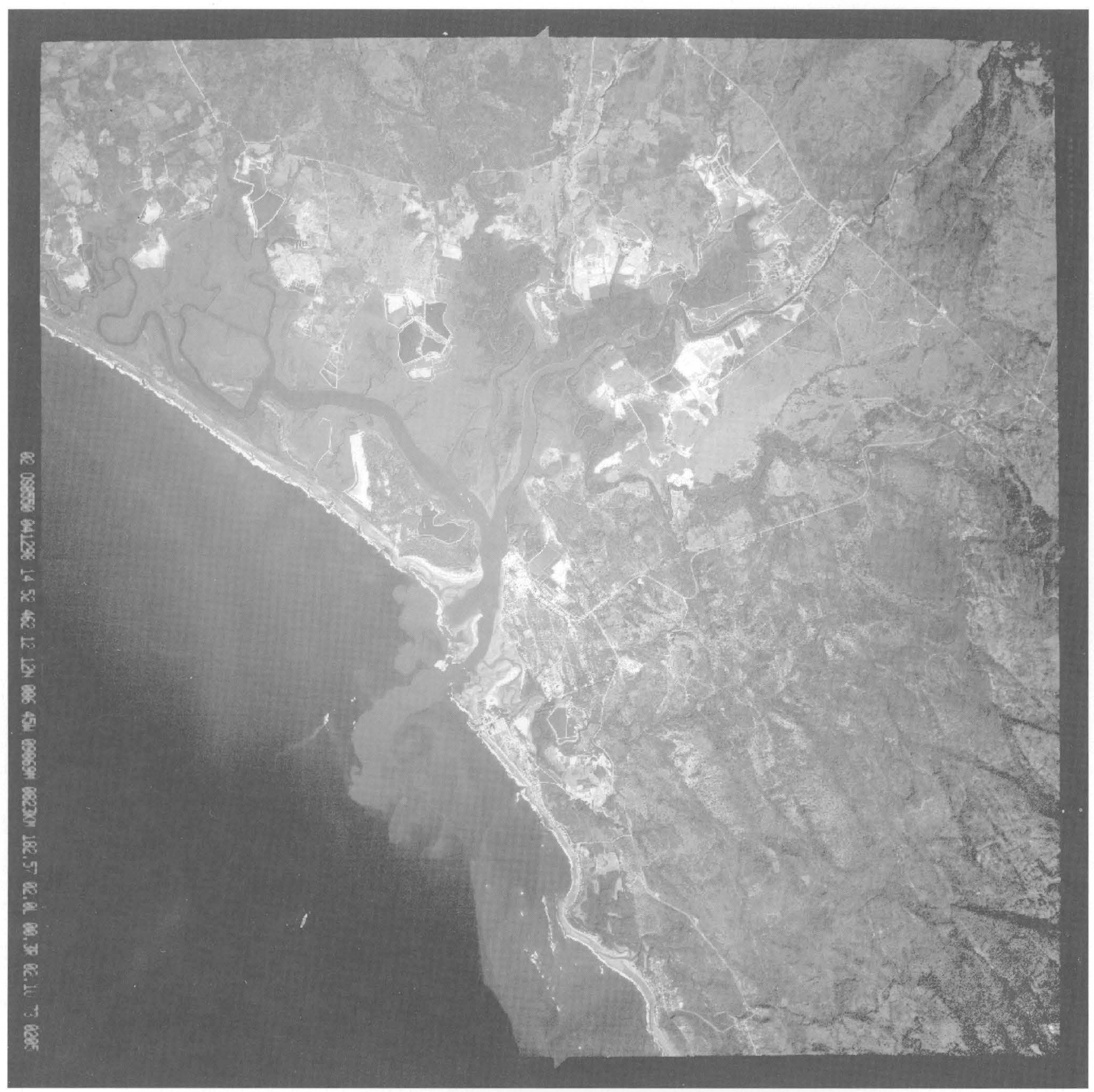

Black-and-white vertical photograph of the Pacific Ocean coastal area and wetlands near El Tamarindo, Nicaragua. Much sediment was deposited along the banks of the Rio Tamarindo, in the diked salt ponds, at the mouth of the bay, and in the coastal wetlands. Although this photograph was made 5 weeks after the storm, a large quantity of suspended sediment is still flowing into the Pacific Ocean as a plume. Part of the wetland area was flooded and experienced significant changes in salinity. 


\section{Topographic map corresponding to}

Frame 549-December 4, 1998-19:01:34

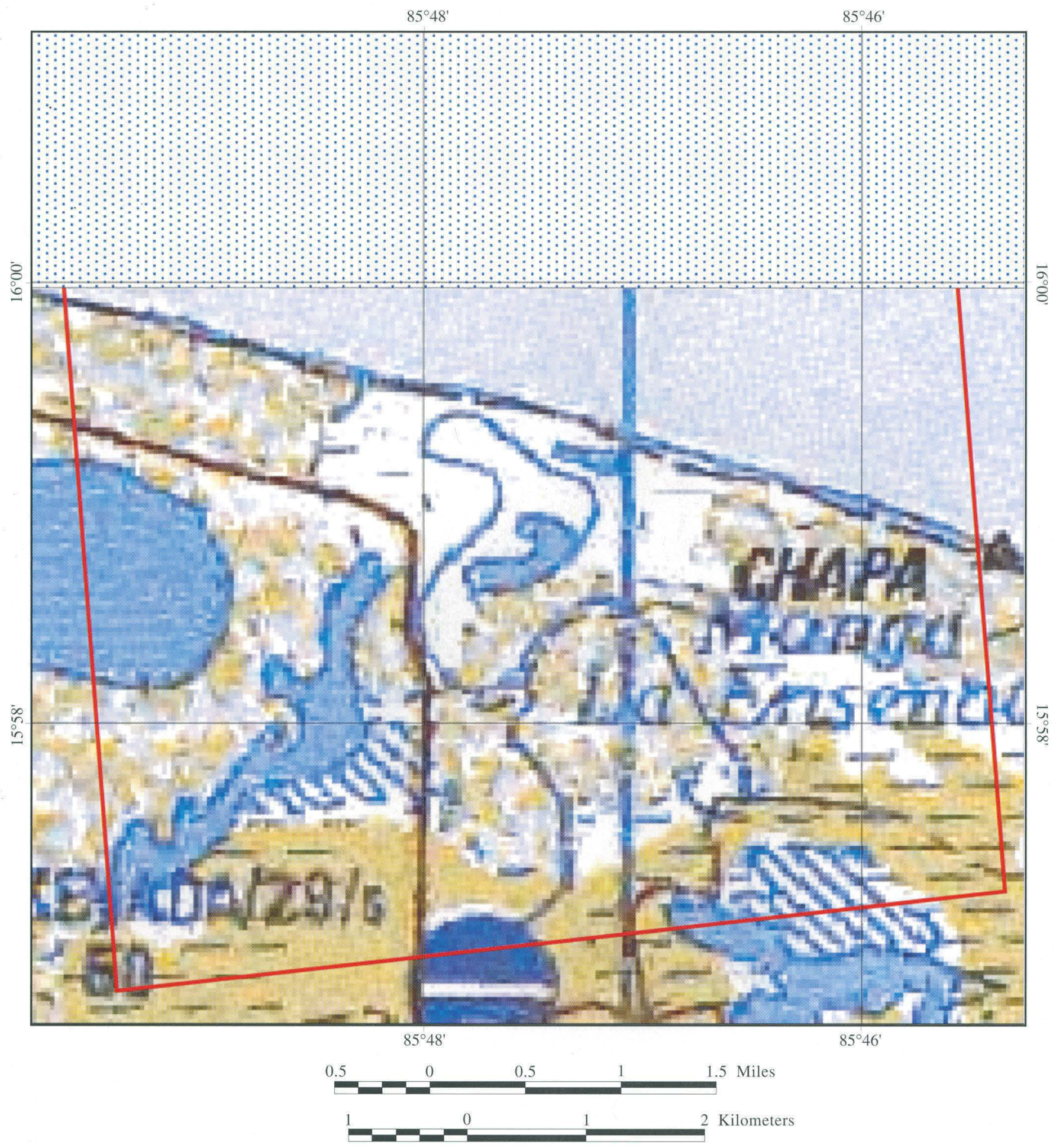

Map Source: 1:250,000-scale DMA topographic maps of Central America 


\section{Caribbean Coast, East of Trujillo, Honduras}

Frame 549-December 4, 1998-19:01:34

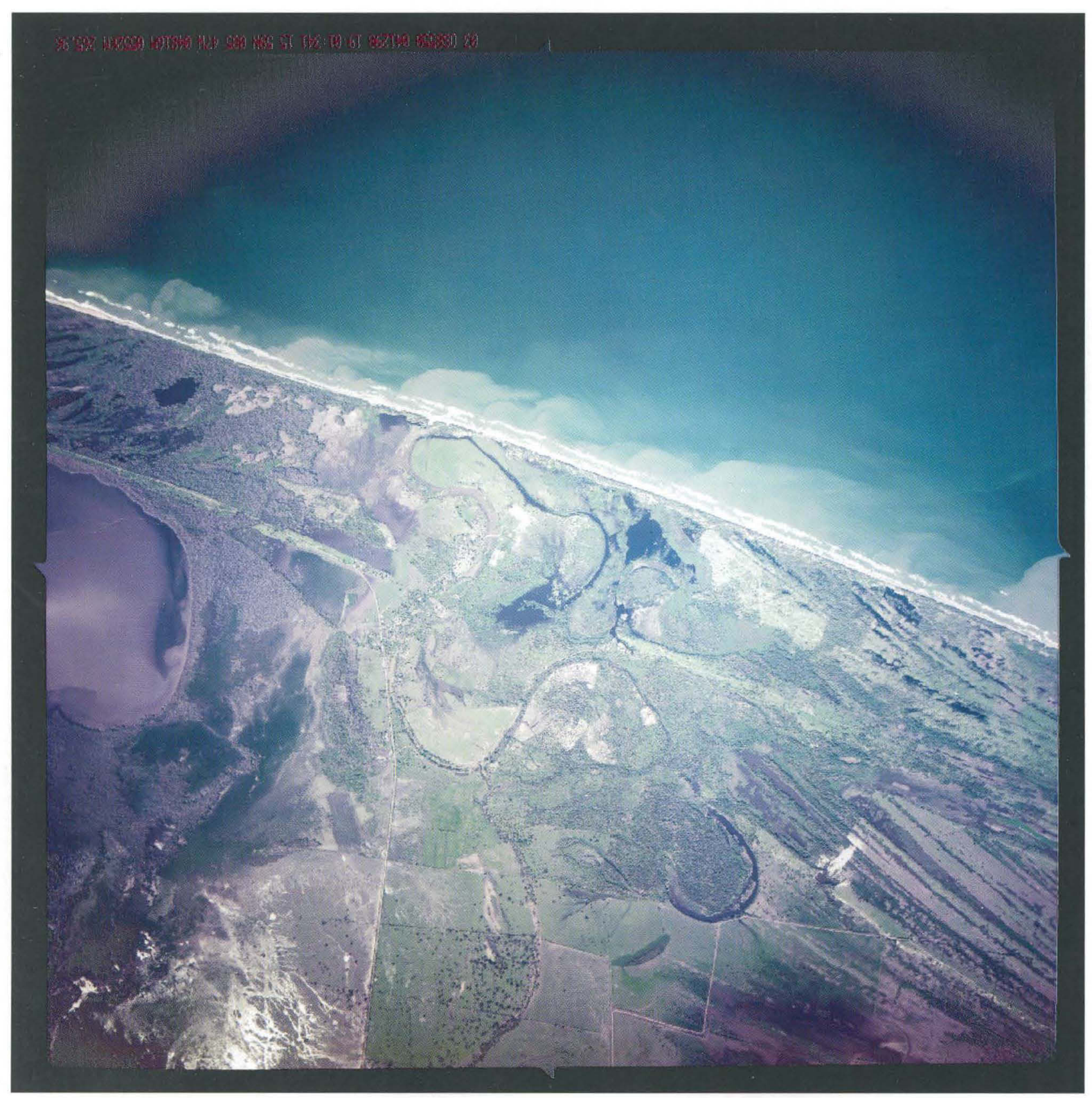

Color vertical photograph of the Caribbean Sea coastline and adjacent wetlands, east of Trujillo, Honduras. Many beaches were covered by large quantities of logs and other debris transported by flooding rivers from the interior of Honduras. A large amount of sediment was still being transported eastward, 5 weeks after the storm. Several inland areas show evidence of flooding and sediment deposition from high water. 


\section{Topographic map corresponding to}

\section{Frame 645-December 4, 1998-19:37:05}

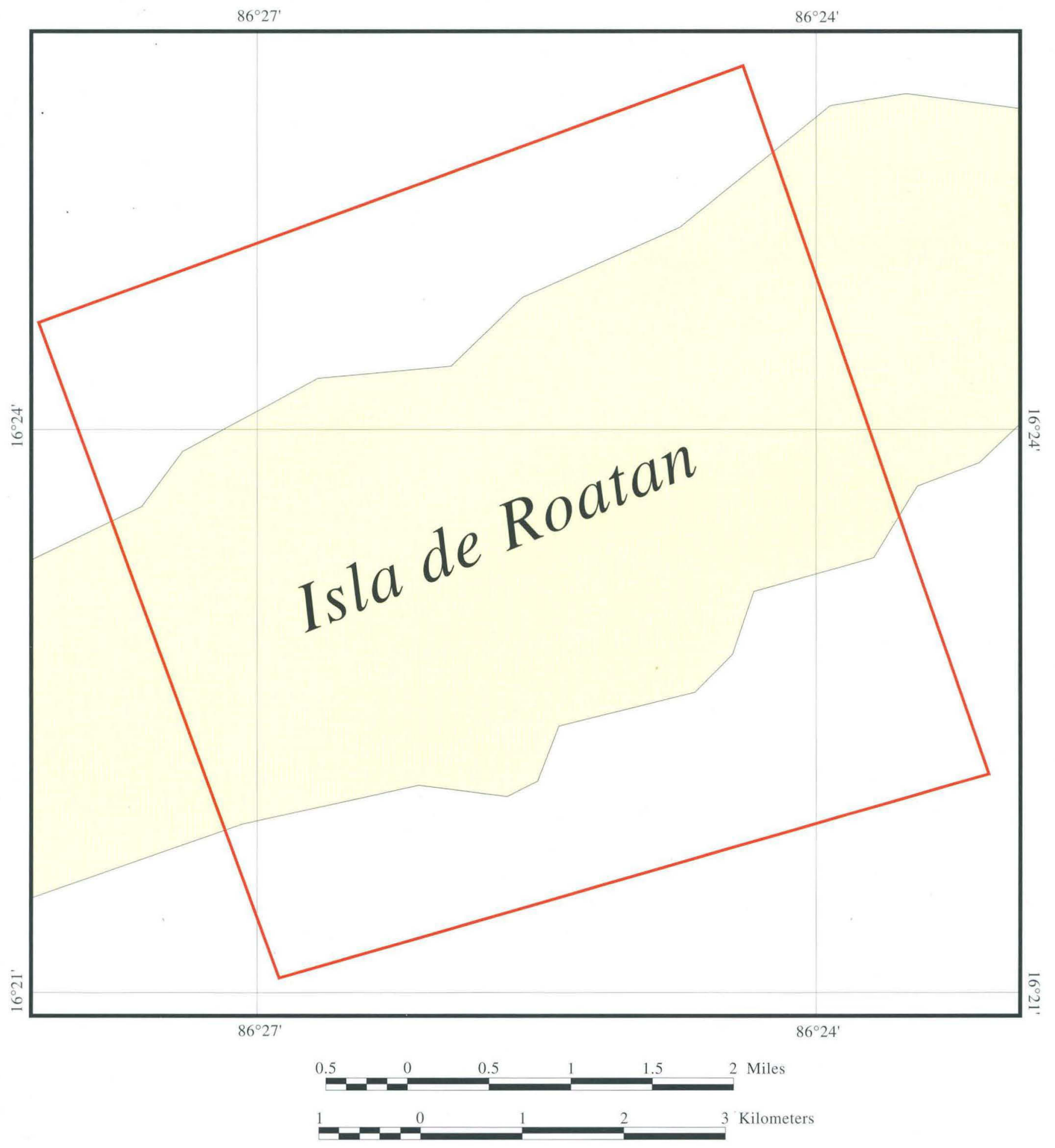

Map Source: 1:250,000-scale DMA topographic maps of Central America 


\section{Isla de Roatan, Honduras}

\section{Frame 645-December 4, 1998-19:37:05}

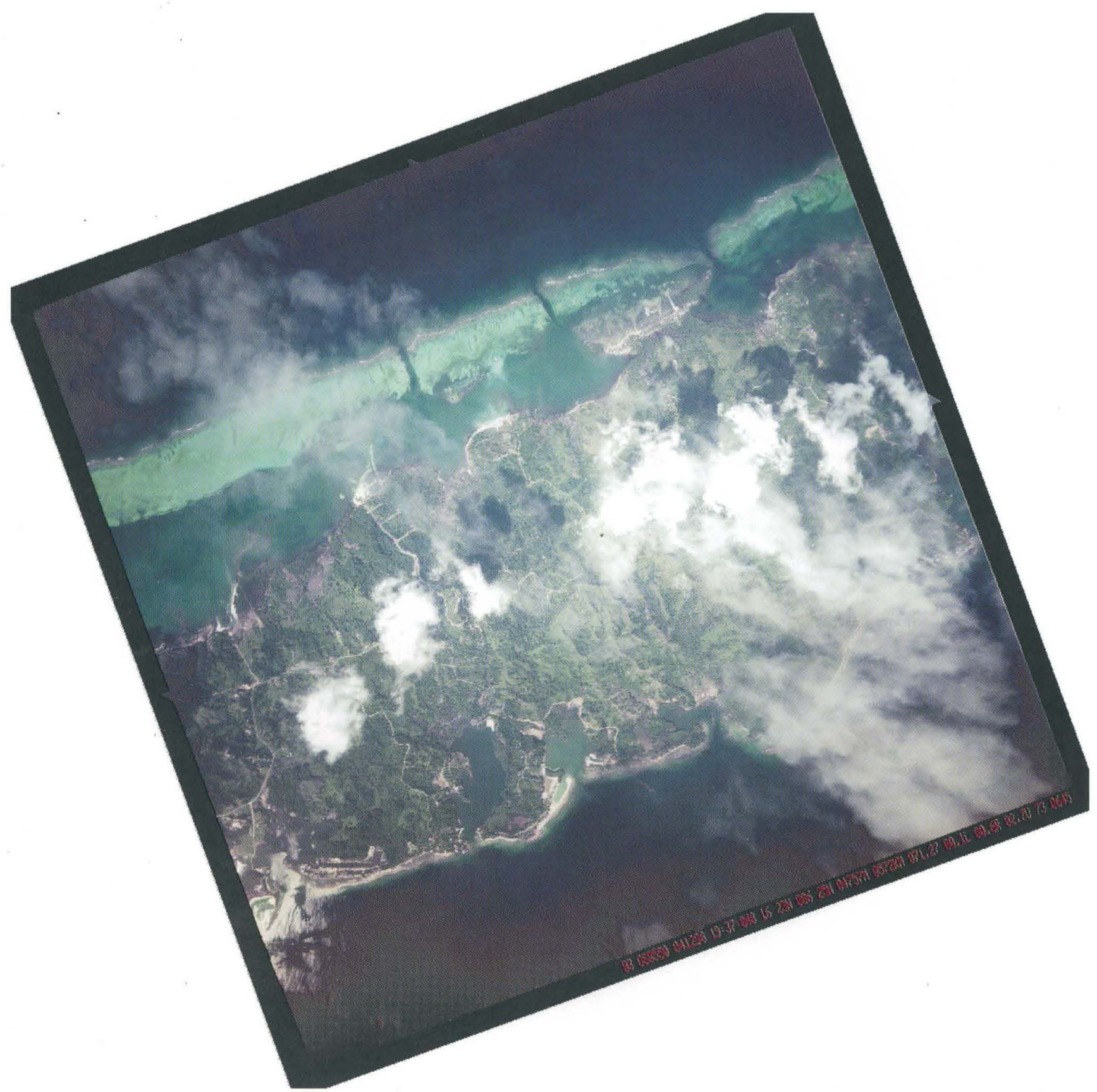

Color vertical photograph of the central part of the Isla de Roatan, one of the Caribbean islands in the Honduran Islas de la Bahia group. These islands were photographed for analysis of the impact of Hurricane Mitch on coral reefs and coastal barrier islands.

Preliminary analyses indicate that although many of the reefs show erosional grooves, major destruction of these reefs did not occur. However, the potentially destructive impact of suspended sediment blocking light transmission and sediment deposition on the reefs cannot be evaluated from aerial photography. Elsewhere, extensive reef damage was reported. 


\section{ENLARGEMENTS-EXAMPLES OF THE DETAILS DISCERNABLE ON THE OPEN SKIES PHOTOGRAPHY}

Although full-frame photographs are useful for getting an impression of the impacts of Hurricane Mitch at regional and subregional scales, high-resolution aerial photography can be enlarged to provide much more detailed site-specific information. To demonstrate the substantial information content of the Open Skies photography, multiple enlargements at increasing magnification, some at more than 50 times, were made of two areas south of Casita Volcano, Nicaragua.

Each set consists of a full-frame photograph and at least four successive enlargements, labeled Frame 140, 140-A, 140-B, 140-C, 140-D1, and 140-D2, and frame141, 141-A, 141-B, 141-C, and 141-D. Latitude and longitude are displayed on enlargements 140-A, 140-B, 141-A, and 141-B. Both sets of enlargements center on parts of the Casita Volcano massive rock avalanche and debris flow that killed more than 2,000 people.

The rock avalanche originated with the detachment of a large slab of rock, about 1.5 times the area of a football field and more than 65 feet thick, from just below the summit of the Casita Volcano. More than 200,000 cubic yards of rock material avalanched down the flank of the volcano and traveled as much as 2 miles, moving as fast as 50 feet per second. This rock avalanche mass destroyed the village of Bella Vista. Several hours later, a debris flow originated from the avalanche deposit and traveled downslope, following existing gullies, including the Quebrade El Mono Muerto. The debris flow, which was about 10 feet high, destroyed the villages of El Porvenir and Rolando Rodriguez, located about 2 miles downstream from the avalanche mass. More than 2,000 people were killed at these locations. Another 1.5 miles downstream, the debris flow expanded to its maximum width of about a mile. Most of the remaining sediment was deposited in this area, but two narrow fingers of debris flowed an additional 10 miles downstream, following existing channels. The eastern finger of the debris flow material reached the village of Posoltega, where it destroyed houses on the east side of town. Many other villages were partially or completely destroyed by the rock avalanche and debris flows. These include Argelia, Santa Teresa, Santa Narciso, and Las Botijas. 


\section{Posoltega, Nicaragua}

\section{Frame 140}

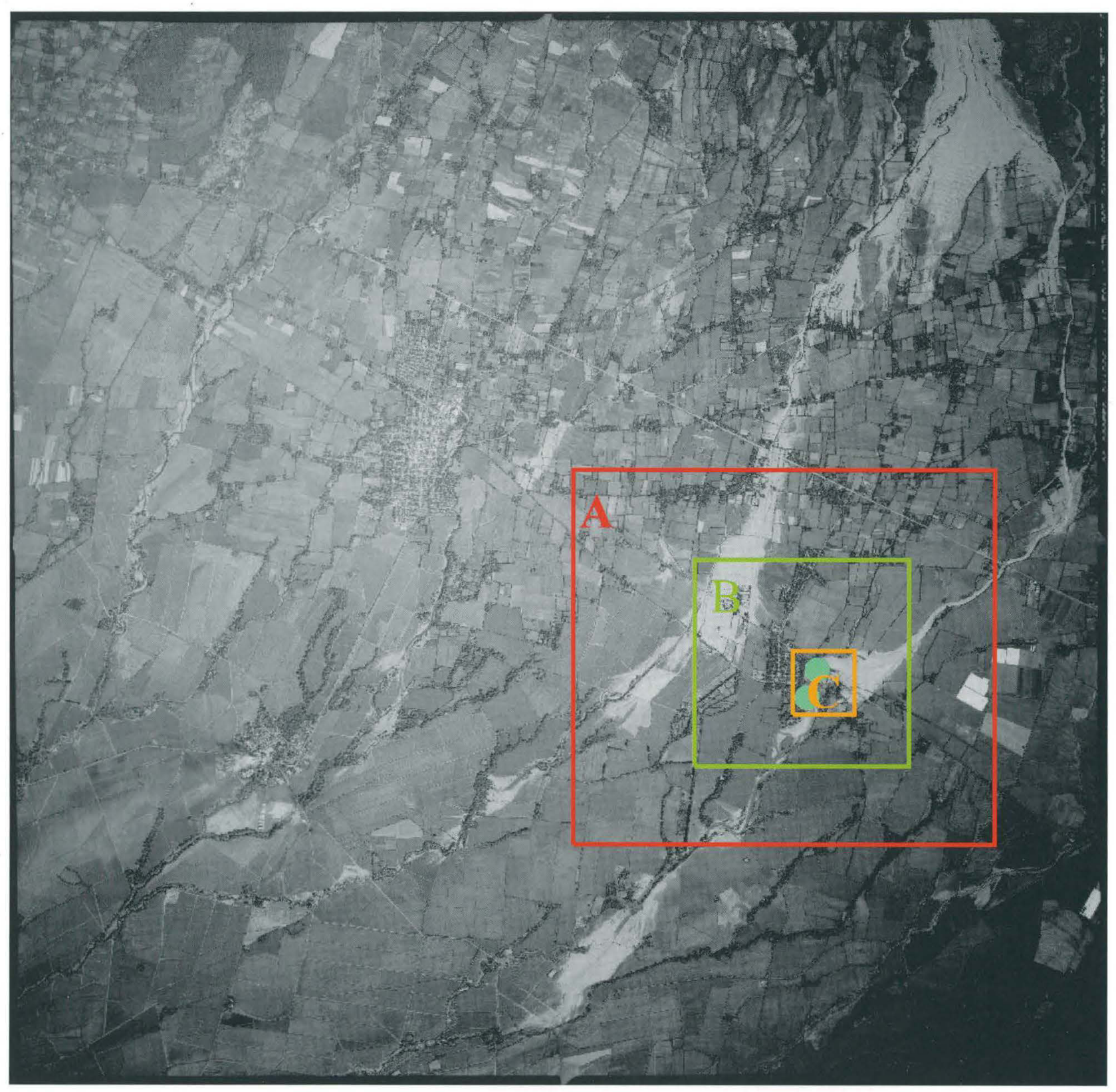

Locations of enlargements A, B, C, D1, and D2 are shown as red, green, and orange boxes, and two blue dots. Enlargements are $\sim 2.5 \mathrm{x}, \sim 5 \mathrm{x}, \sim 17 \mathrm{x}, \sim 45 \mathrm{x}$, and $\sim 45 \mathrm{x}$, respectively.

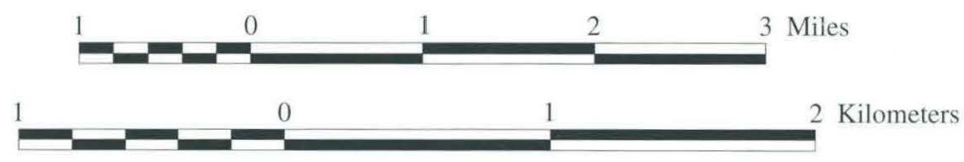




\section{Map corresponding to frame 140}

\section{Enlargements A, B, C, D1, and D2}

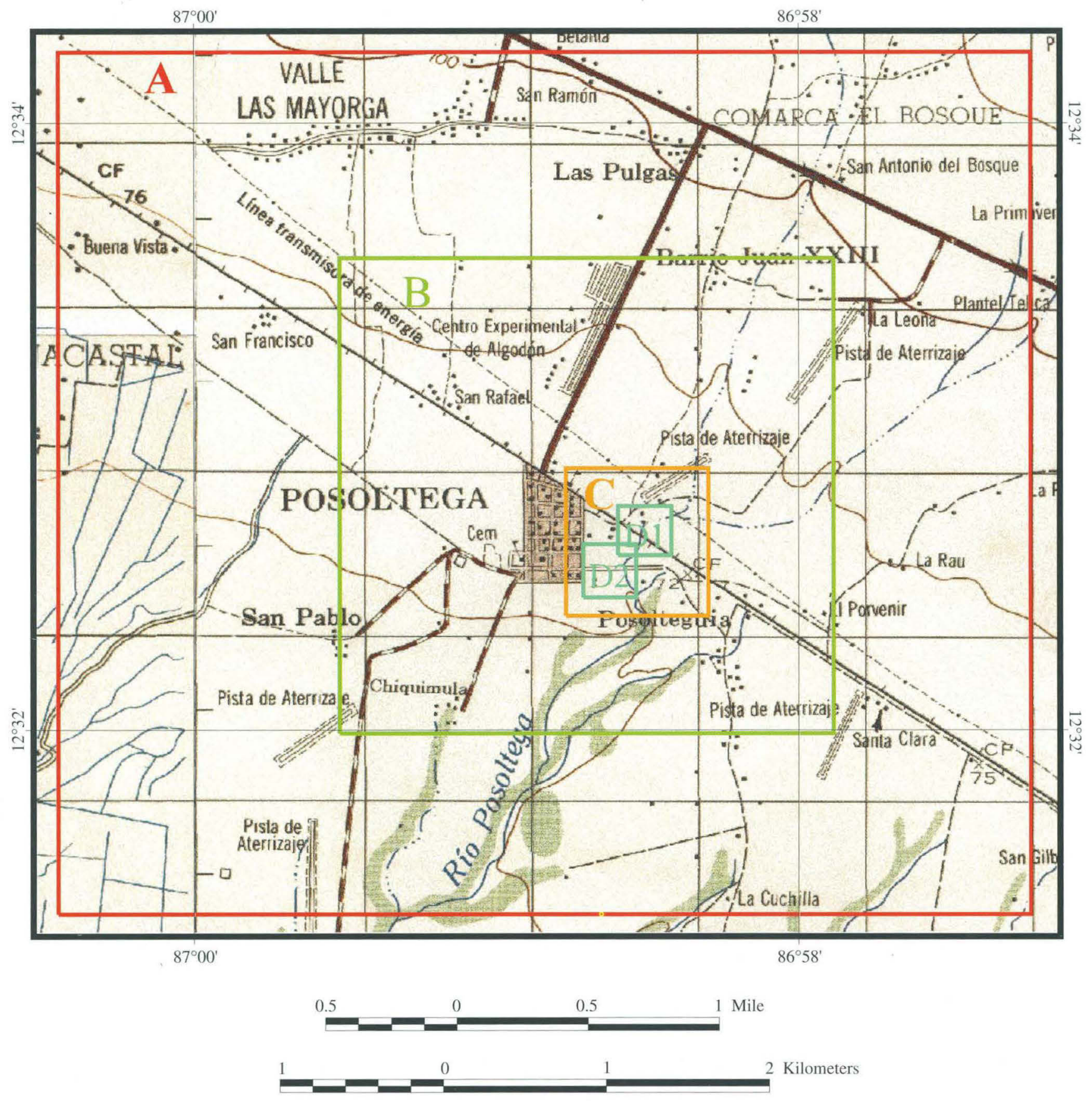




\section{Posoltega, Nicaragua}

Frame 140-A

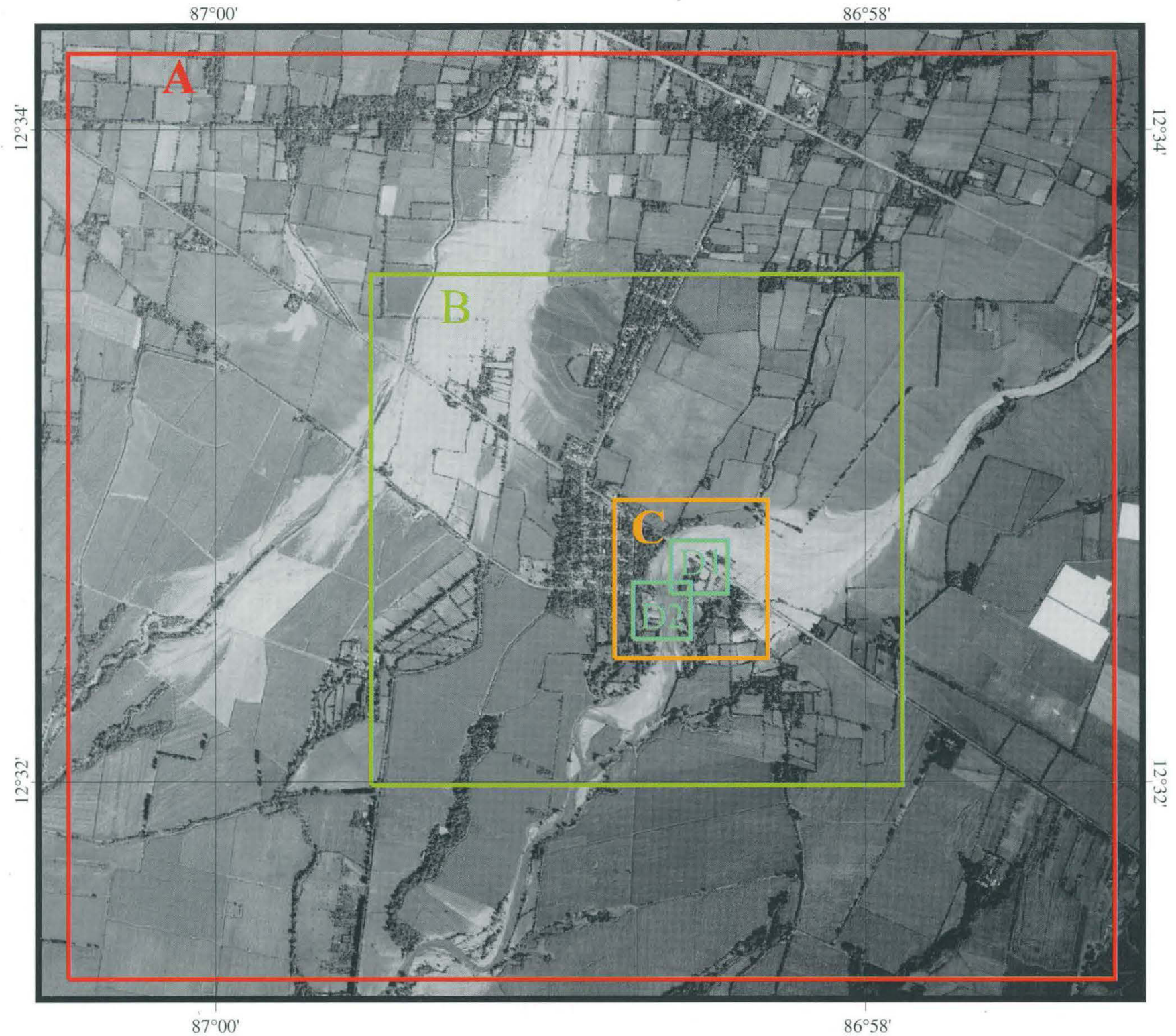

The green, orange, and blue boxes represent the locations of the four areas shown as Enlargements B, C, D1, and D2 on the following pages.

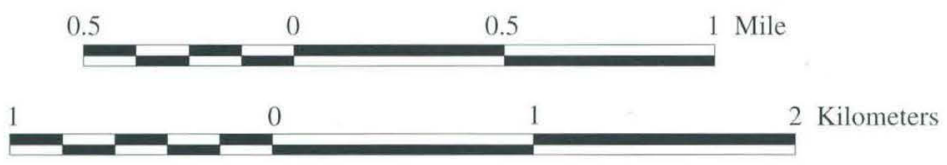




\section{Map corresponding to frame 140-A}

\section{Enlargement: $\sim 2.5 \mathrm{x}$}

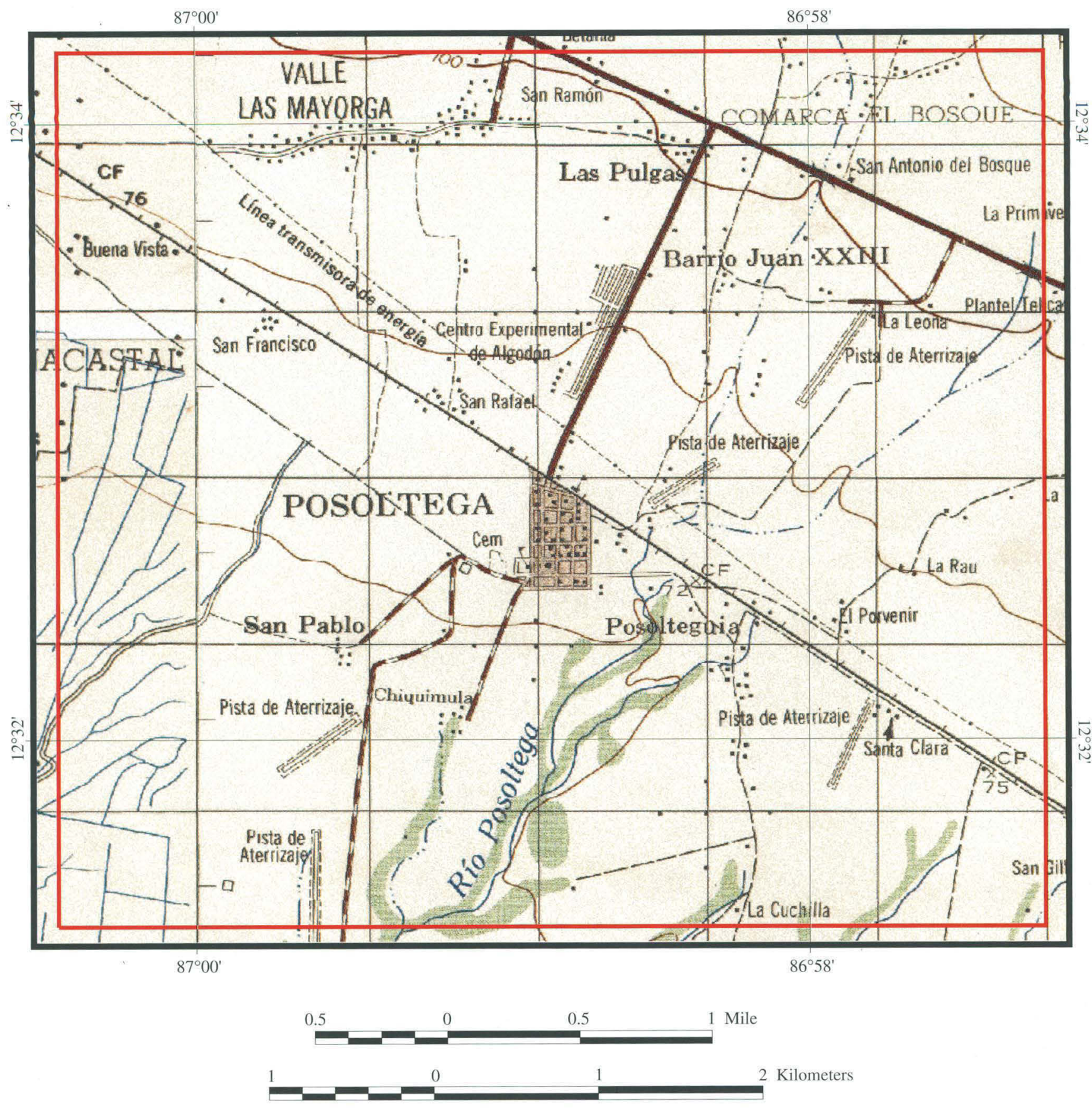

Map Source: 1:50,000-scale DMA topographic map of Nicaragua 


\section{Posoltega, Nicaragua}

\section{Frame 140-A; Enlargement: 2.5x}

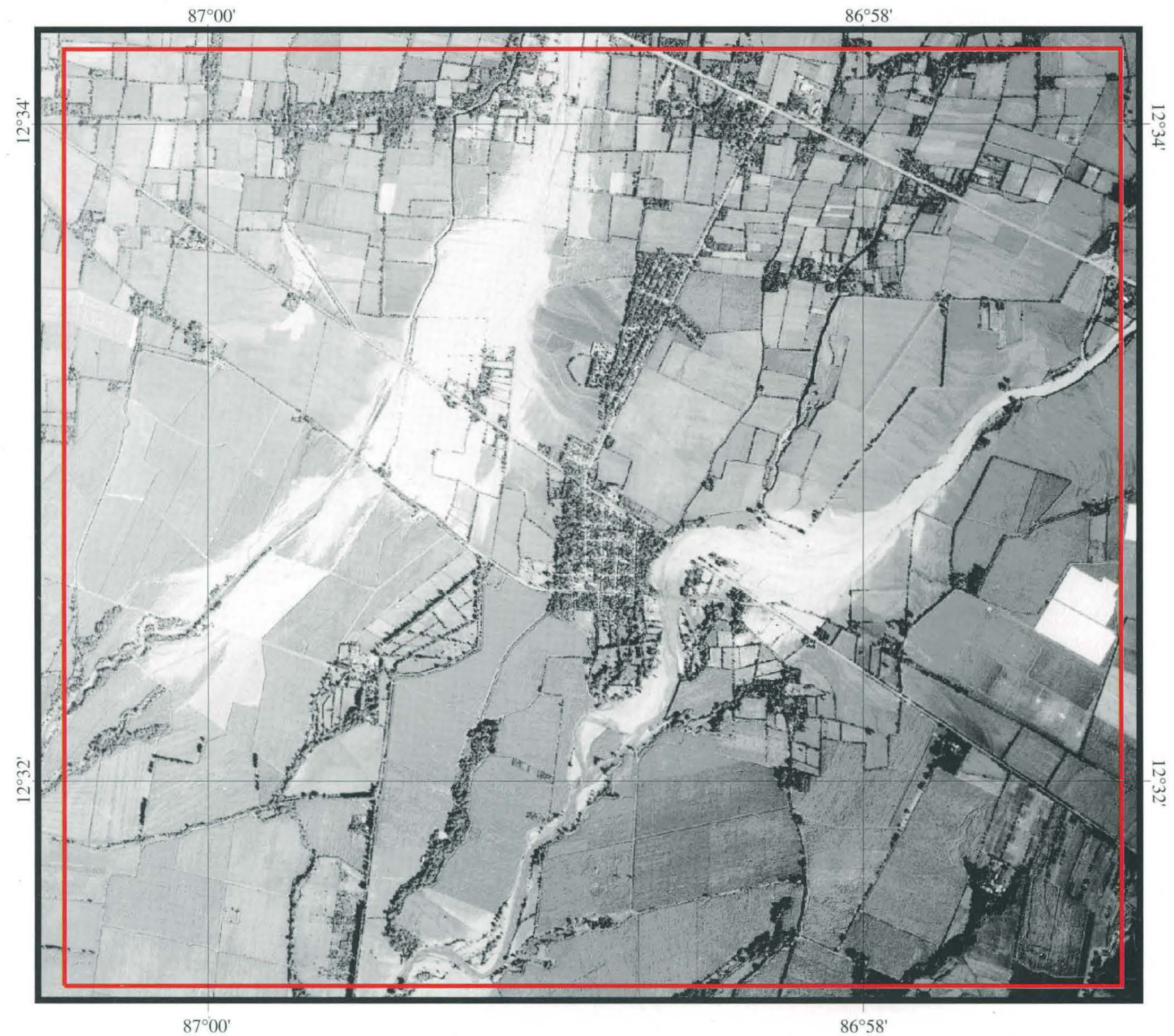

Frame 140-A, a $2.5 x$ enlargement, showing the path of two finger-like limbs of the southern end of the Casita Volcano debris flow, which covered and breached the Inter-American Highway and the local railroad line. The eastern limb flowed through the village of Posoltega, while the western limb flowed through the Valle Las Mayorga. Manmade structures were destroyed at both locations.

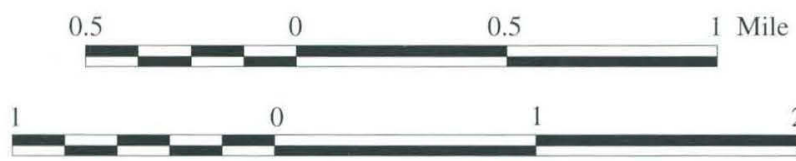

2 Kilometers 


\section{Map corresponding to frame 140-B}

Enlargement: $\sim 5 \mathrm{x}$

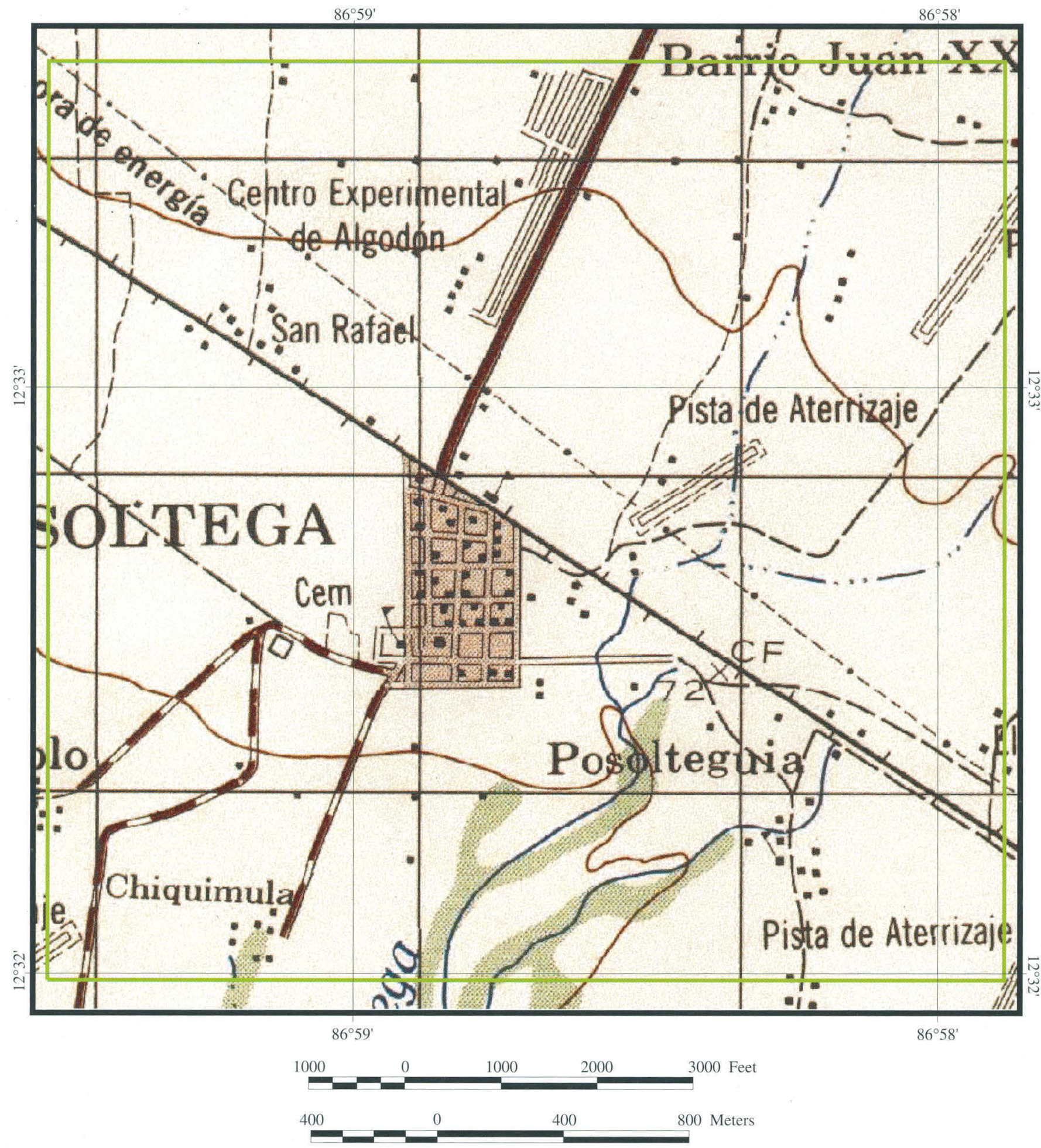




\section{Posoltega, Nicaragua}

\section{Frame 140-B; Enlargement: 5x}

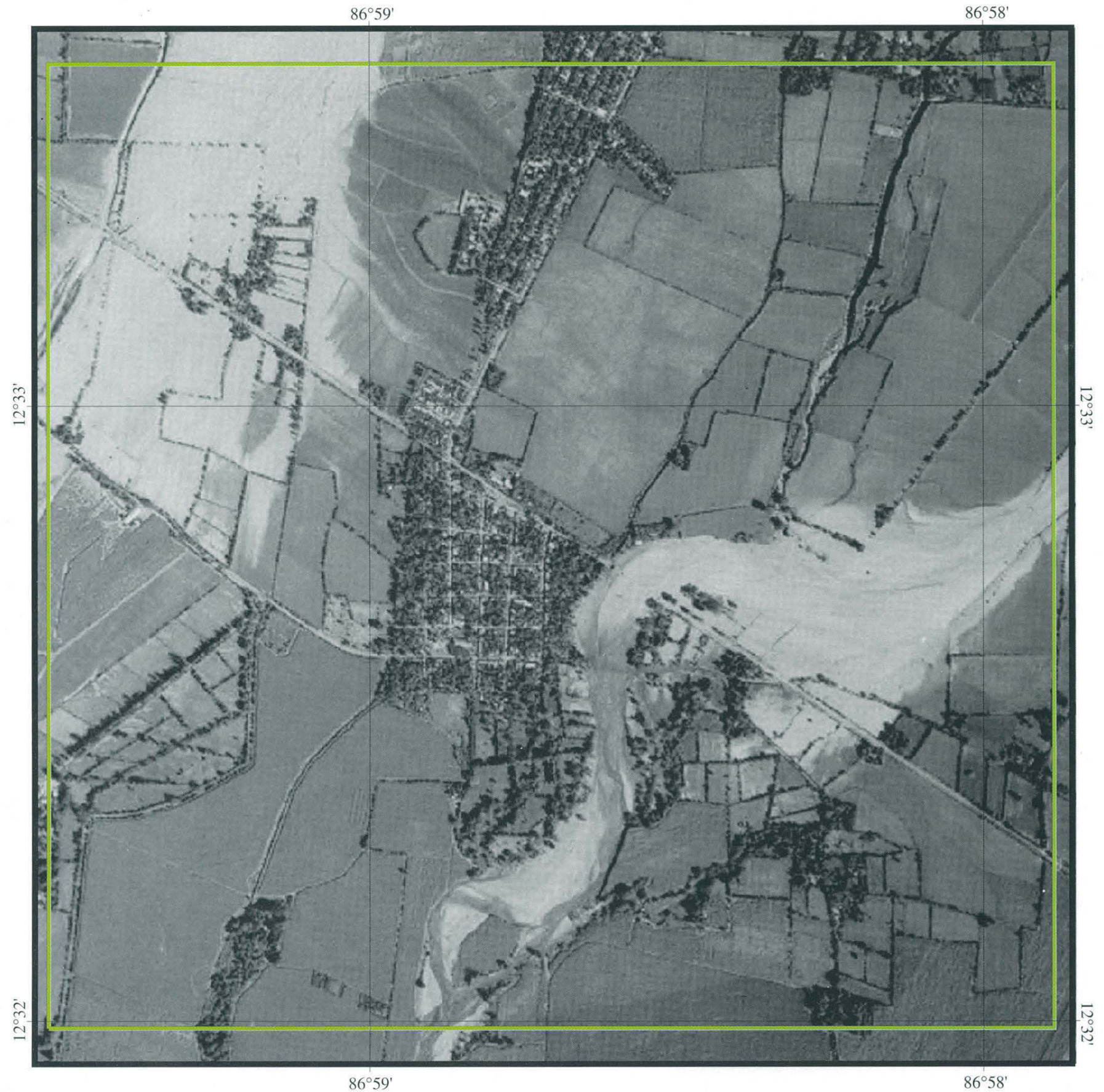

Frame 140-B, a 5x enlargement, showing parts of the path and the deposits of the Casita Volcano debris flow near the village of Posoltega and the Valle Las Mayorga.

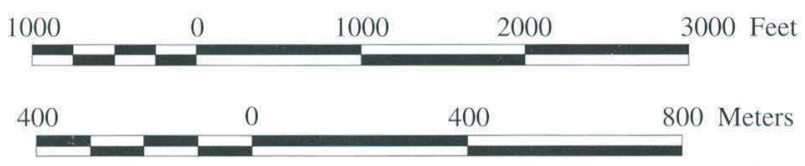




\section{Map corresponding to frame 140-C}

\section{Enlargement: 17x}

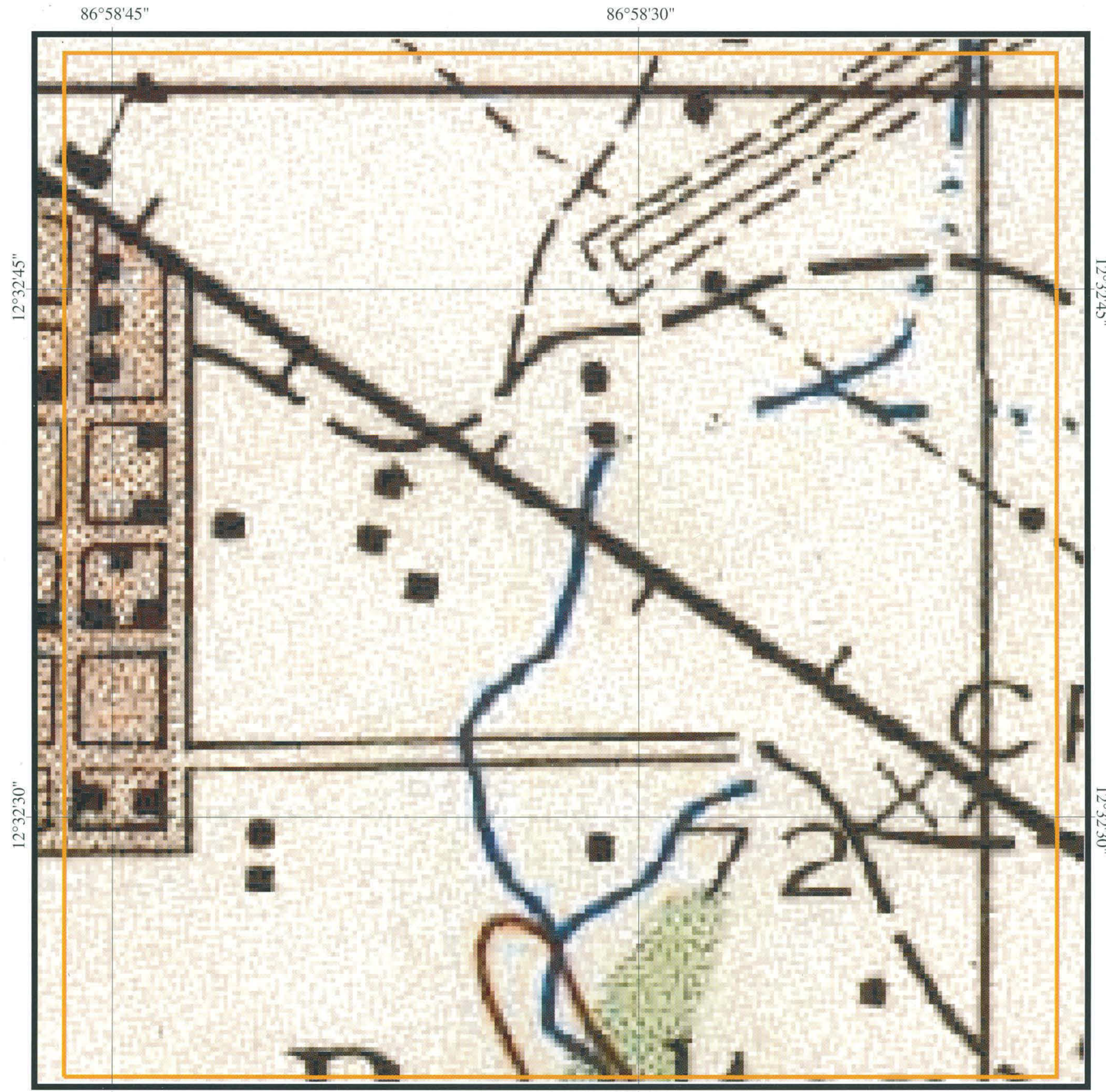

$86^{\circ} 58^{\prime} 45^{\prime \prime}$

$86^{\circ} 58^{\prime} 30^{\prime \prime}$

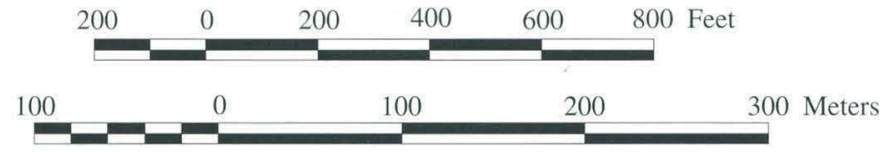

Map Source: 1:50,000-scale DMA topographic map of 


\section{Posoltega, Nicaragua}

\section{Frame 140-C; Enlargement: 17x}

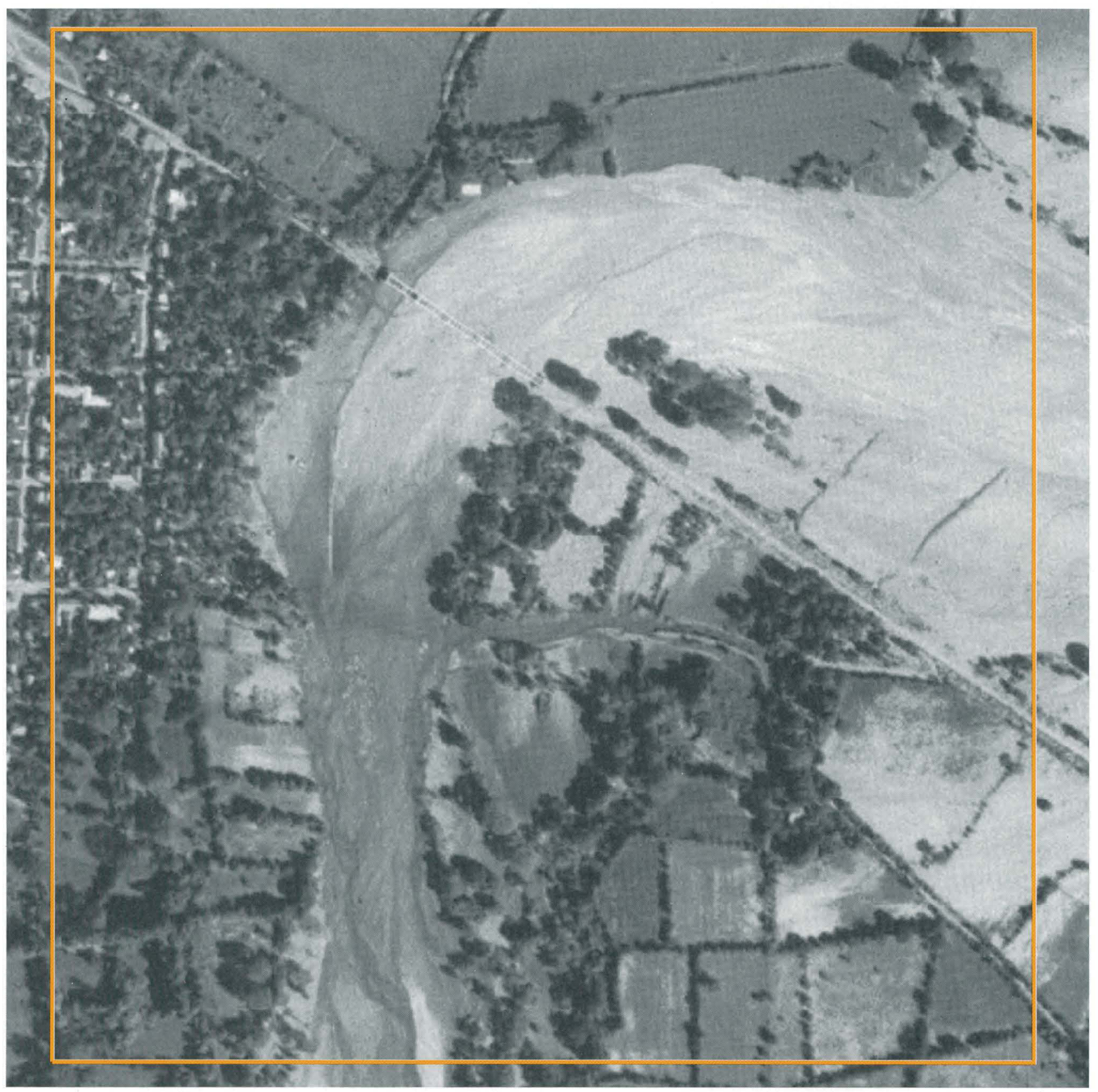

Frame 140-B, a 17x enlargement, showing the path, the deposits, and some of the damage to manmade structures in the village of Posoltega caused by the Casita Volcano debris flow. 


\section{Posoltega, Nicaragua}

\section{Frame 140-D1; Enlargement: $\sim 45 x$}

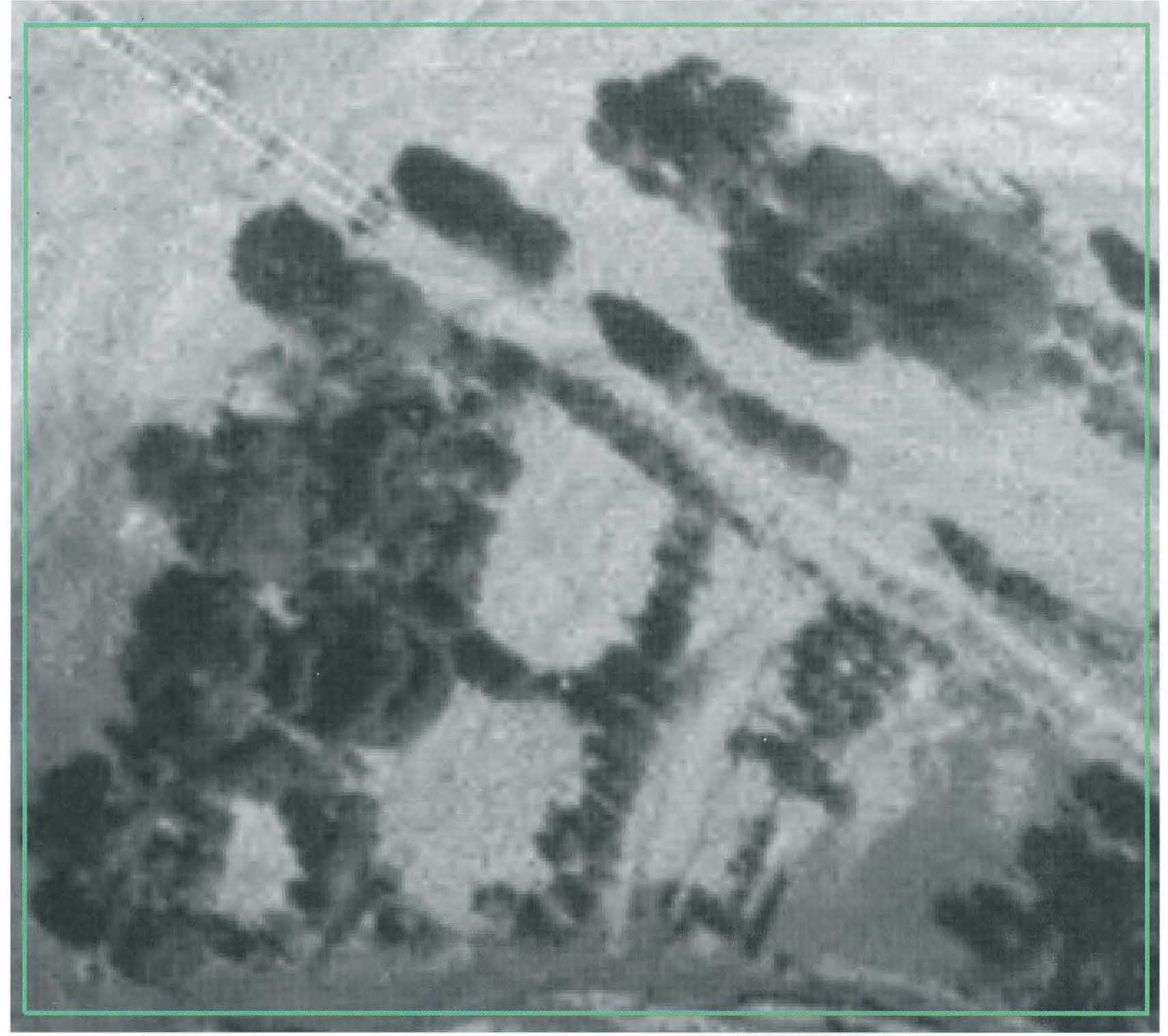

Frame 140-D1, a 45x enlargement of the destroyed railroad tracks east of Posoltega. Individual boulders show as bright reflections in the volcanic debris flow deposits. 


\section{Posoltega, Nicaragua}

\section{Frame 140-D2; Enlargement: $\sim 45 x$}

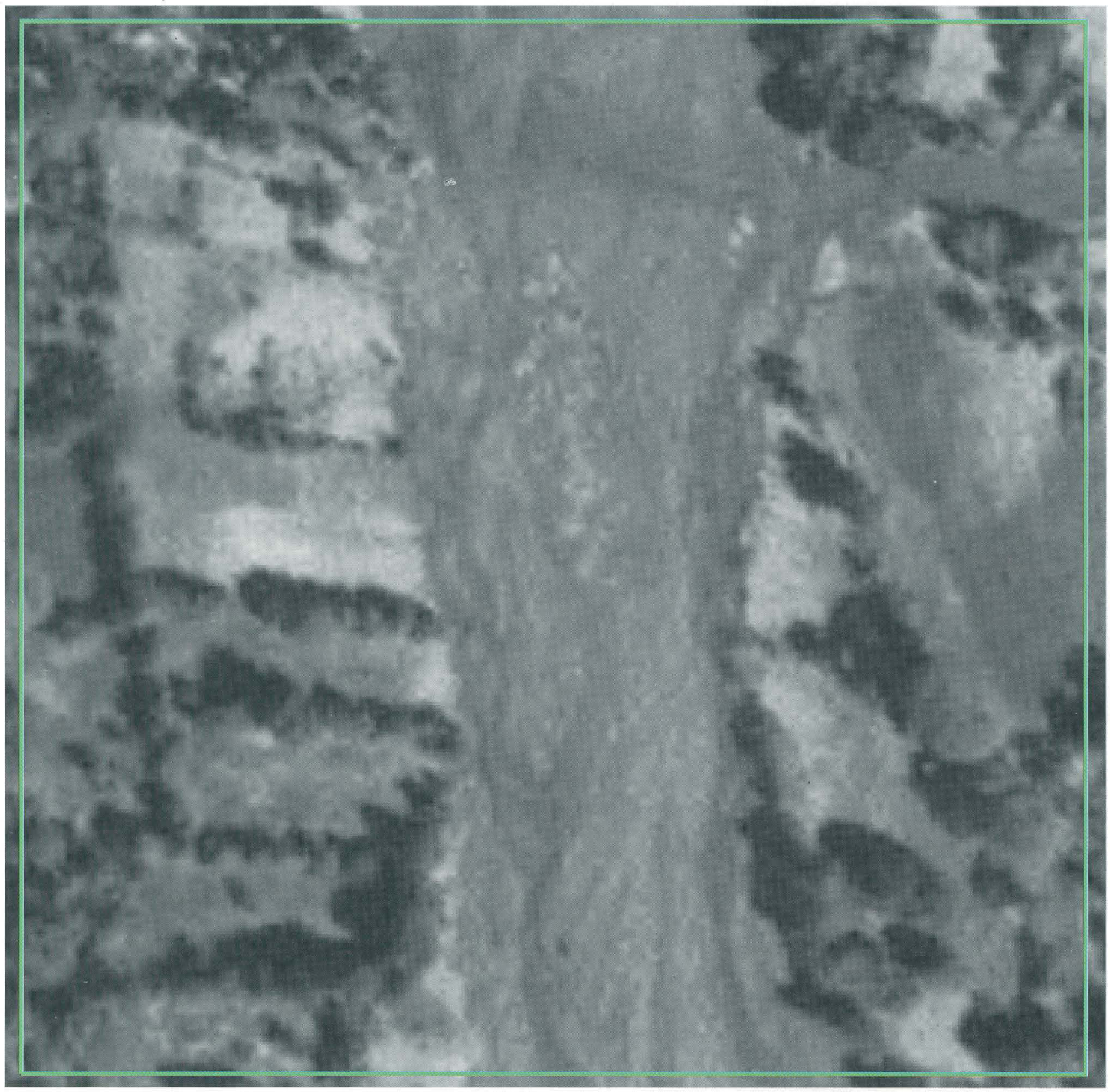

Frame 140-D2, a 45x enlargement of the main pathway of the volcanic debris flow through the east side of the village of Posoltega. Many houses and other structures were destroyed at this location. 


\section{Casita Volcano}
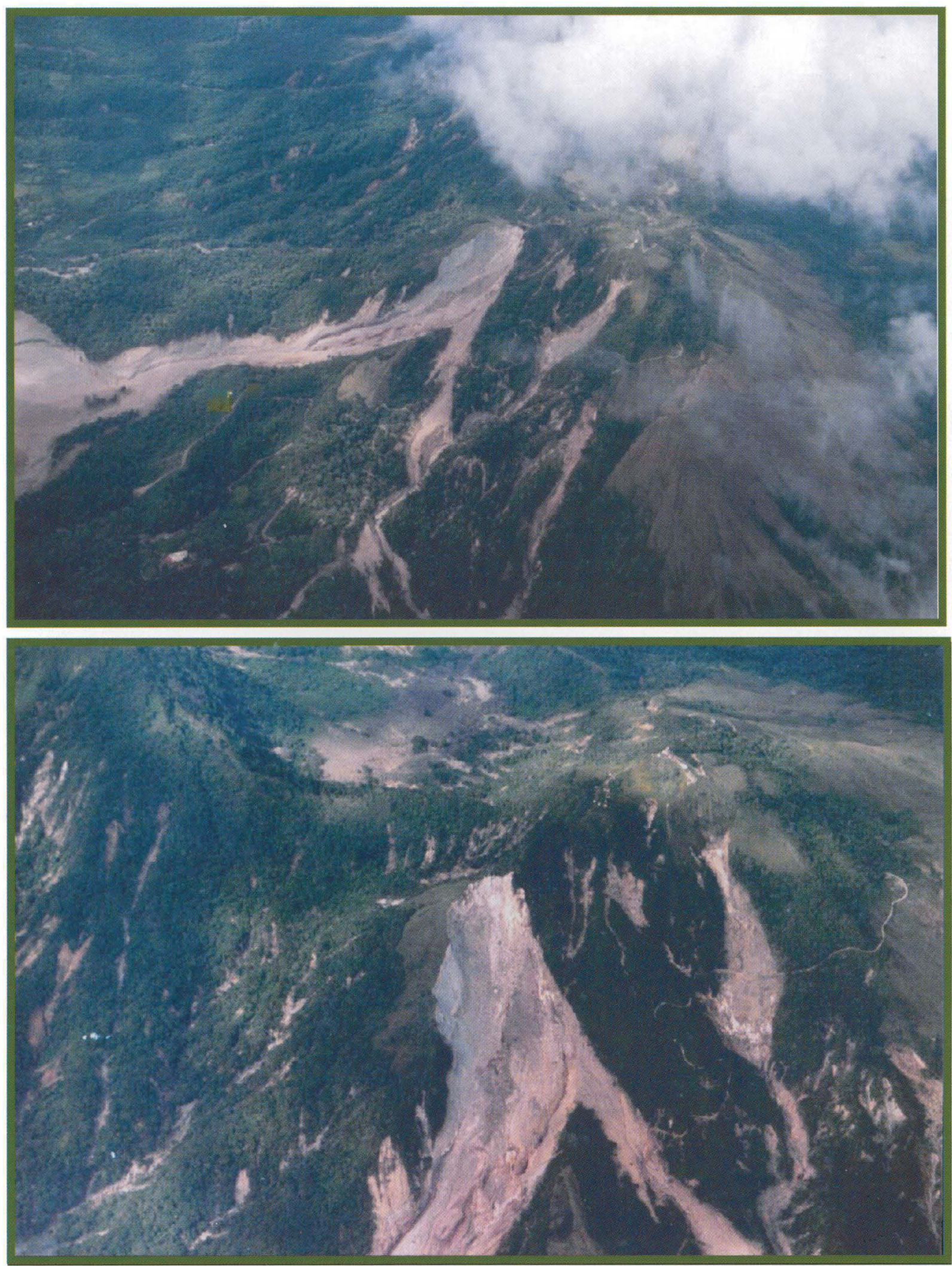

These oblique color photographs show the point of origin near the summit of Casita Volcano of the large rock avalanche and debris flow shown in the next series of enlargements. Additional oblique photographs begin on page 67. (USGS photographs by Bruce F. Molnia - OS-3 at top and OS-4 at bottom - December 15, 1998) 


\section{Casita Volcano Debris Flow, Nicaragua}

Frame 141

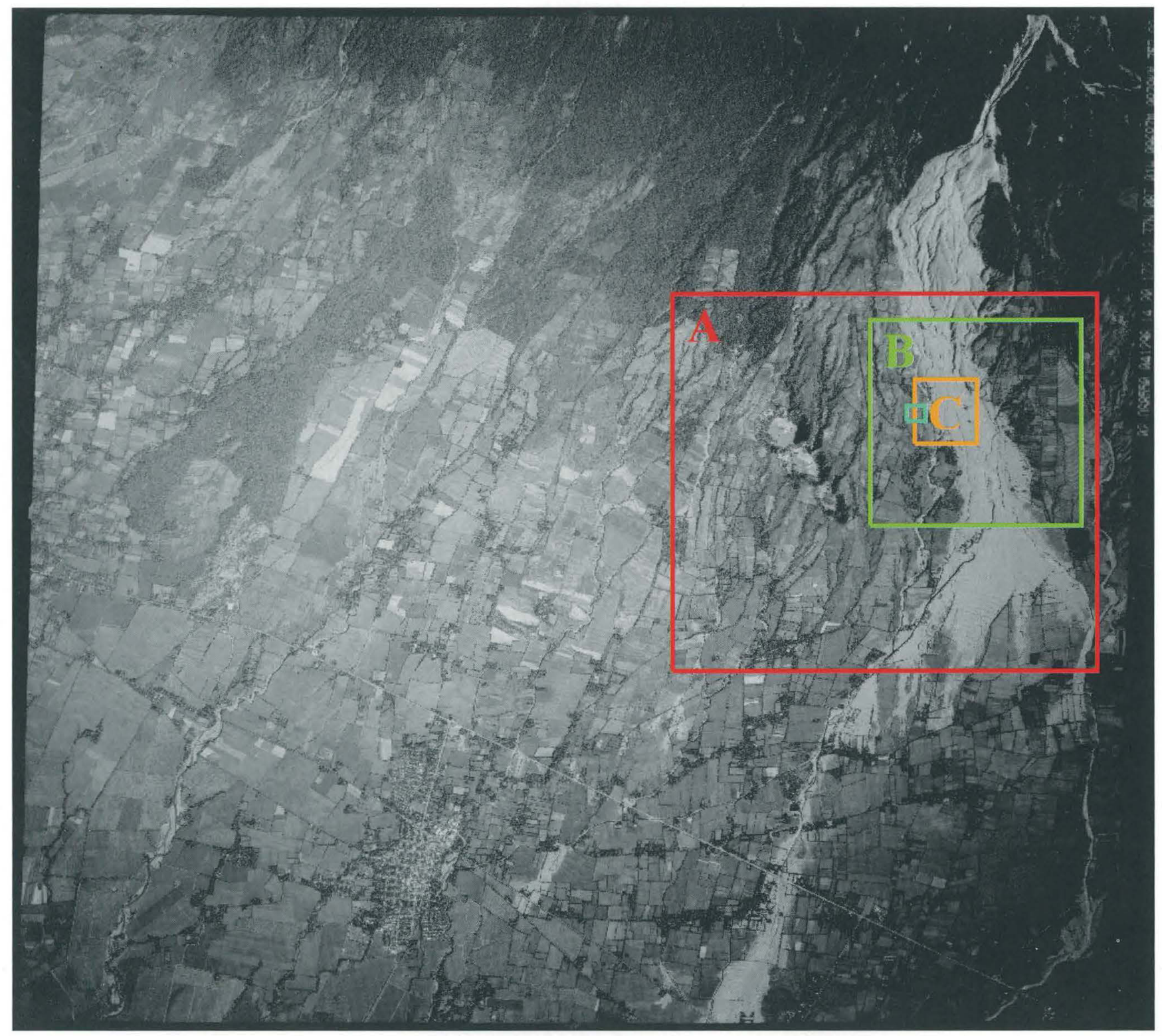

Locations of enlargements A, B, C, and D are shown as red, green, orange, and blue boxes. Enlargements are $\sim 2.5 \mathrm{x}, \sim 5 \mathrm{x}, \sim 17 \mathrm{x}$, and $\sim 55 \mathrm{x}$, respectively.

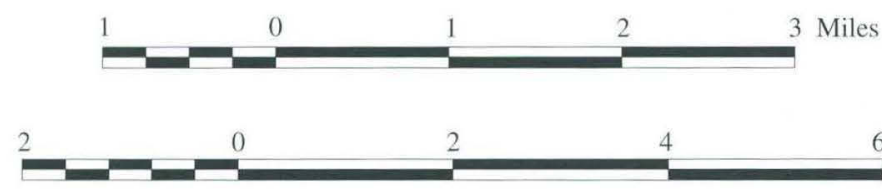

6 Kilometers 


\section{Map corresponding to frame 141-A}

\section{Enlargements A, B, C, and D}

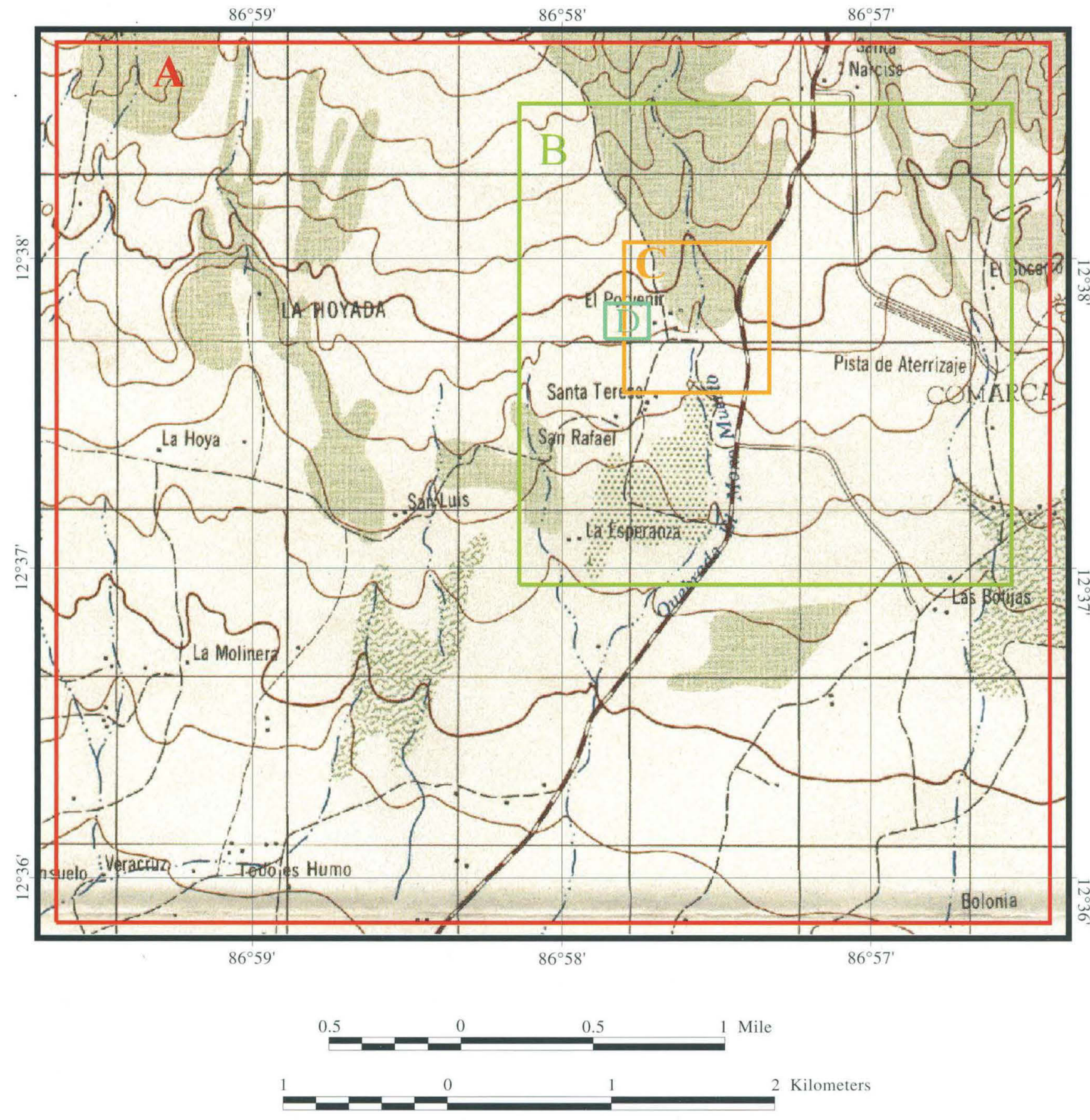

Map Source: 1:50,000-scale DMA topographic map of Nicaragua 


\section{El Porvenir \& Rolando Rodriguez, Nicaragua}

Frame 141-A

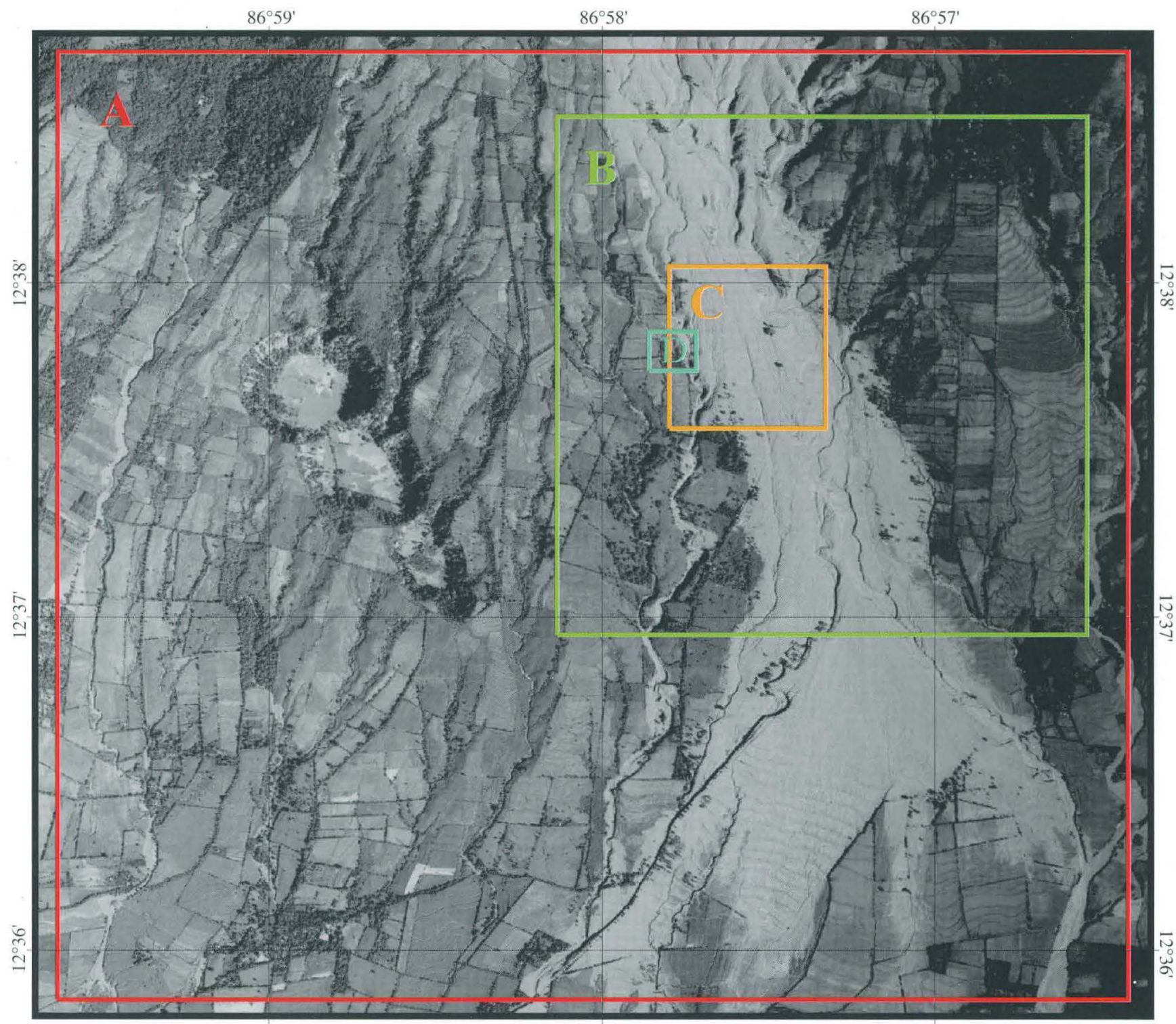

$86^{\circ} 59^{\prime}$

$86^{\circ} 58^{\prime}$

$86^{\circ} 57^{\prime}$

The green, orange, and blue boxes represent the locations of the three areas shown as Enlargements B, C, and D on the following pages. The location of El Porvenir is shown on the accompanying map. Rolando Rodriguez, located to the east of El Porvenir, is not shown because its construction postdates the printing of the map.

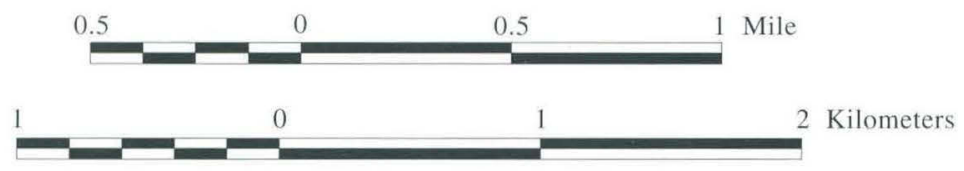




\section{Map corresponding to frame 141-A}

\section{Enlargements: $\sim 2.5 \mathrm{x}$}

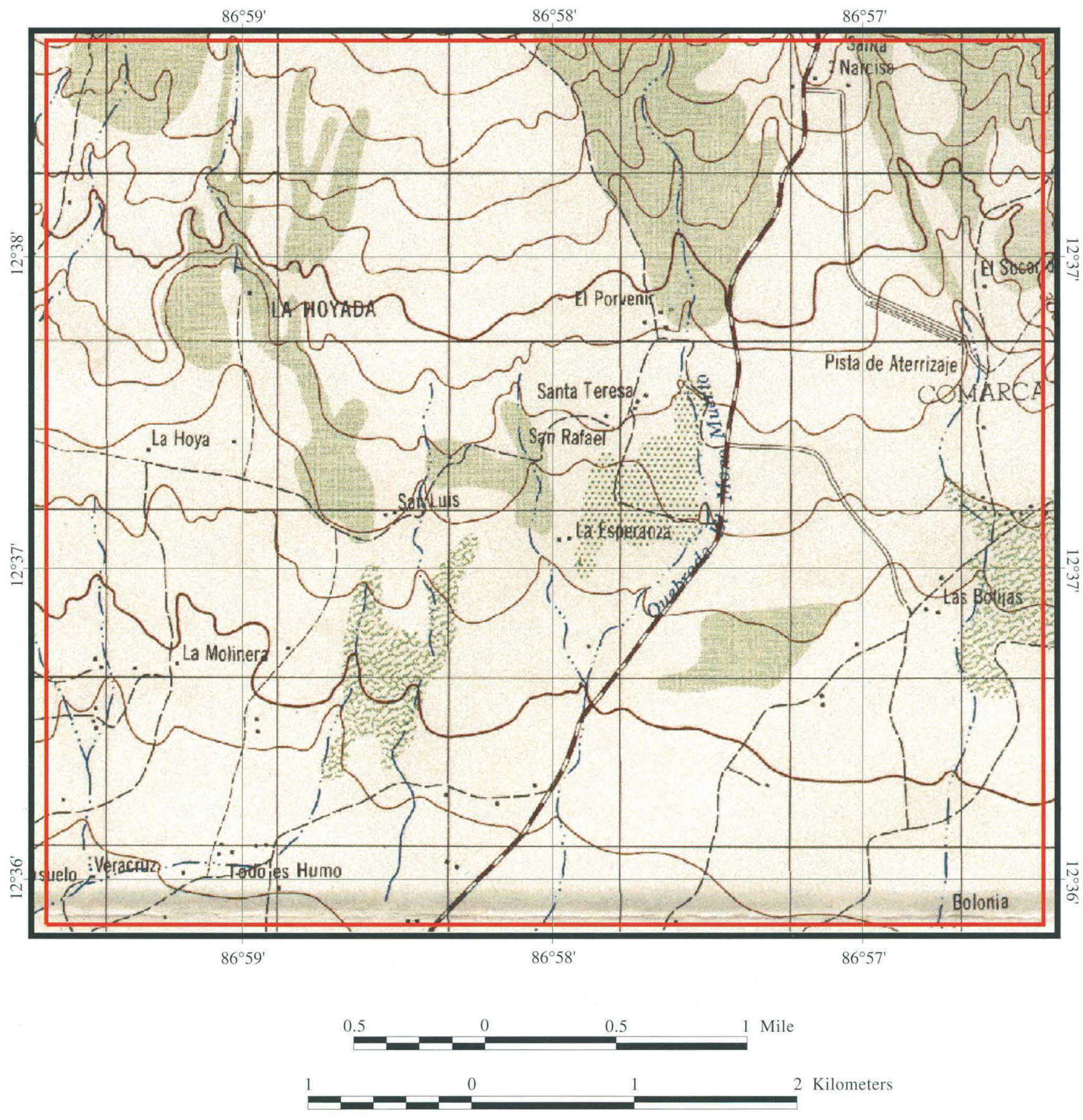




\section{El Porvenir \& Rolando Rodriguez, Nicaragua}

\section{Frame 141-A; Enlargement: 2.5x}

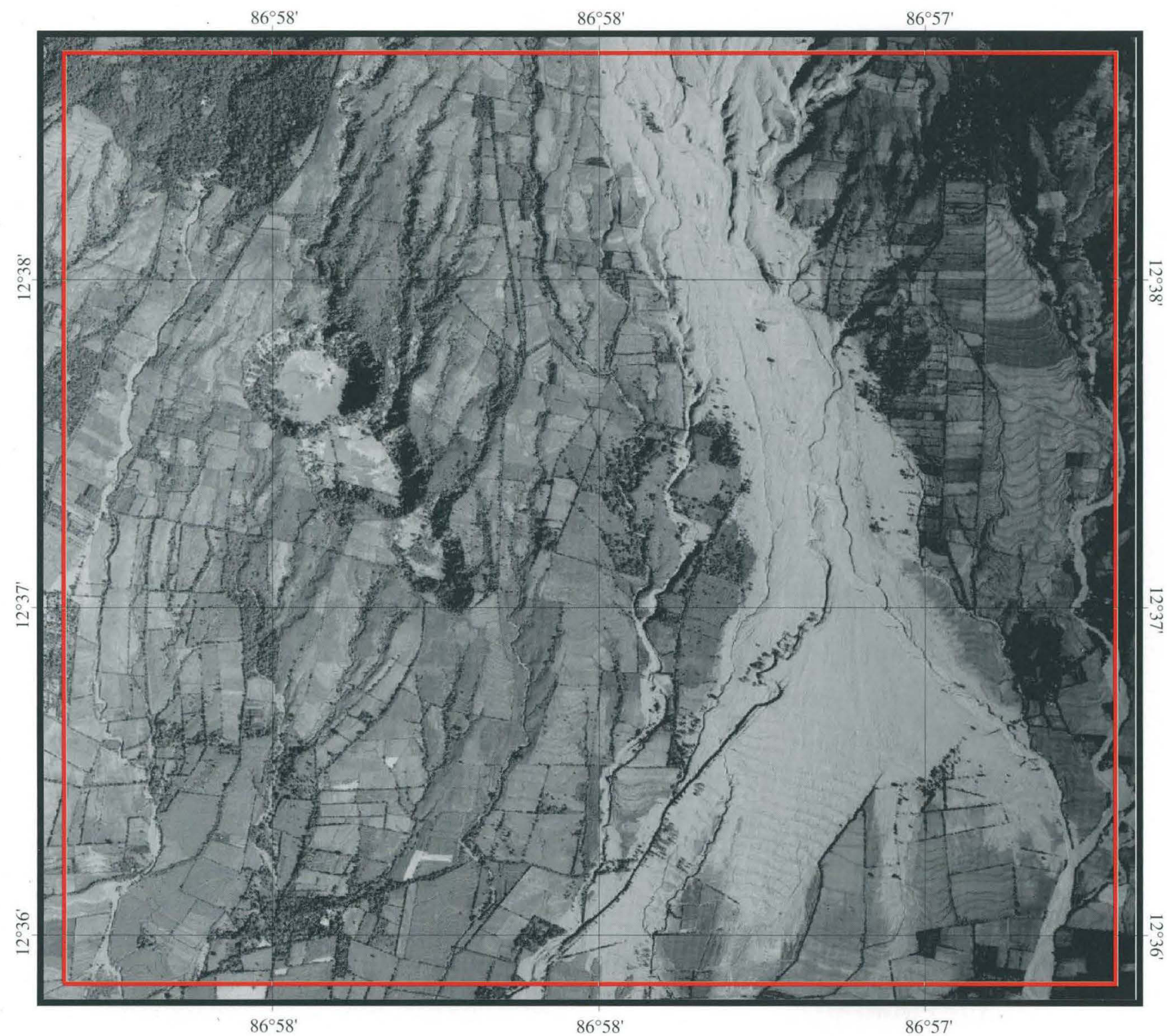

Frame 141-A, a 2.5x enlargement, showing agricultural fields and most of the upper part of the debris-flow deposits in the vicinity of the villages of El Porvenir and Rolando Rodriguez. The location of El Porvenir is shown on the accompanying map. Rolando Rodriguez, located to the east of El Porvenir, is not shown because its construction postdates the printing of the map.

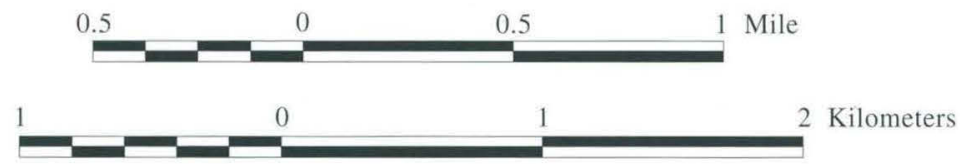




\section{Map corresponding to frame 141-B}

\section{Enlargements: $\sim 5 \mathrm{x}$}

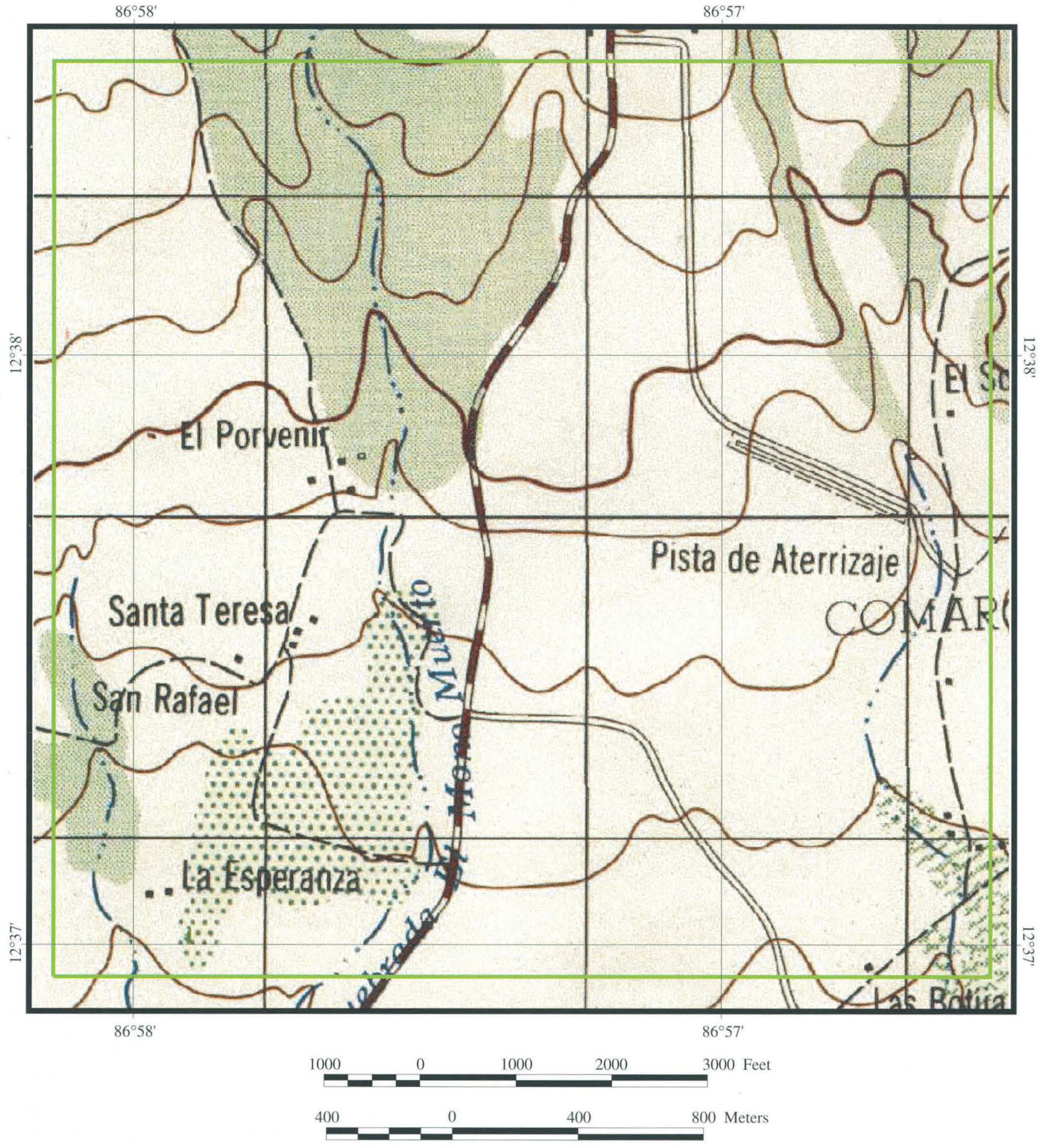

Map Source: 1:50,000-scale DMA topographic map of Nicaragua 


\section{El Porvenir \& Rolando Rodriguez, Nicaragua}

\section{Frame 141-B; Enlargement: 5x}

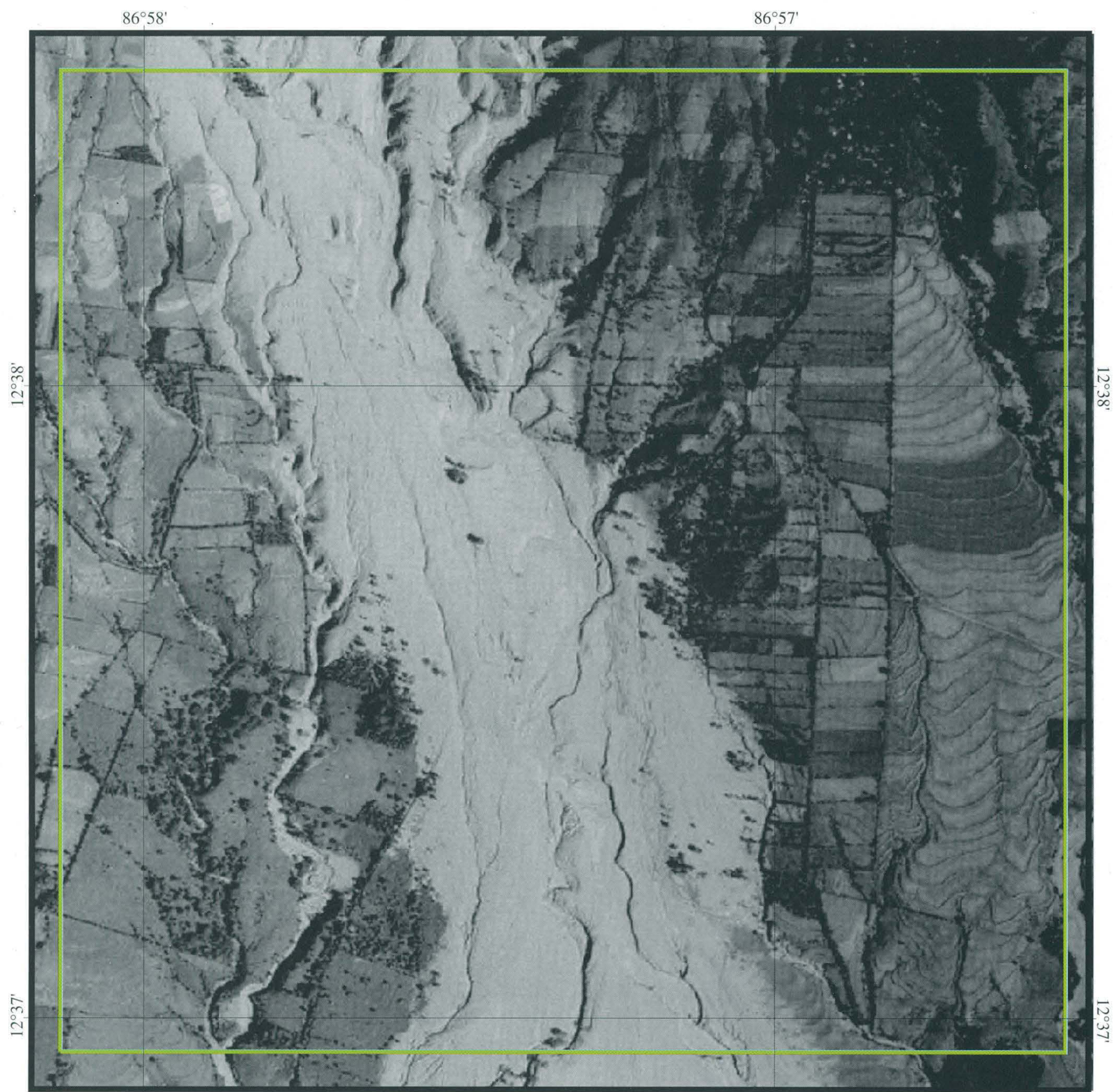

$86^{\circ} 58^{\prime}$

$86^{\circ} 57^{\prime}$

Frame 141-B, a 5x enlargement, showing the main path of the volcanic debris-flow that covered the villages of El Porvenir and Rolando Rodriguez. Channels in the sediment deposits and sediment-covered terraces in adjacent farm fields can be seen. No trace of either village can be seen. The location of El Porvenir is shown on the accompanying map. Rolando Rodriguez, located to the east of El Porvenir, is not shown because its construction postdates the printing of the map.

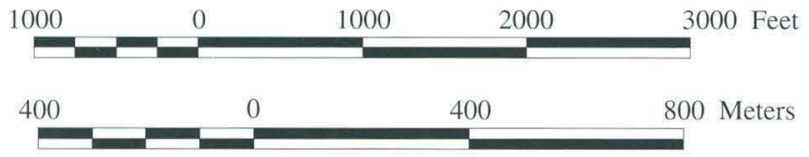




\section{Map corresponding to frame 141-C}

Enlargements: 17x

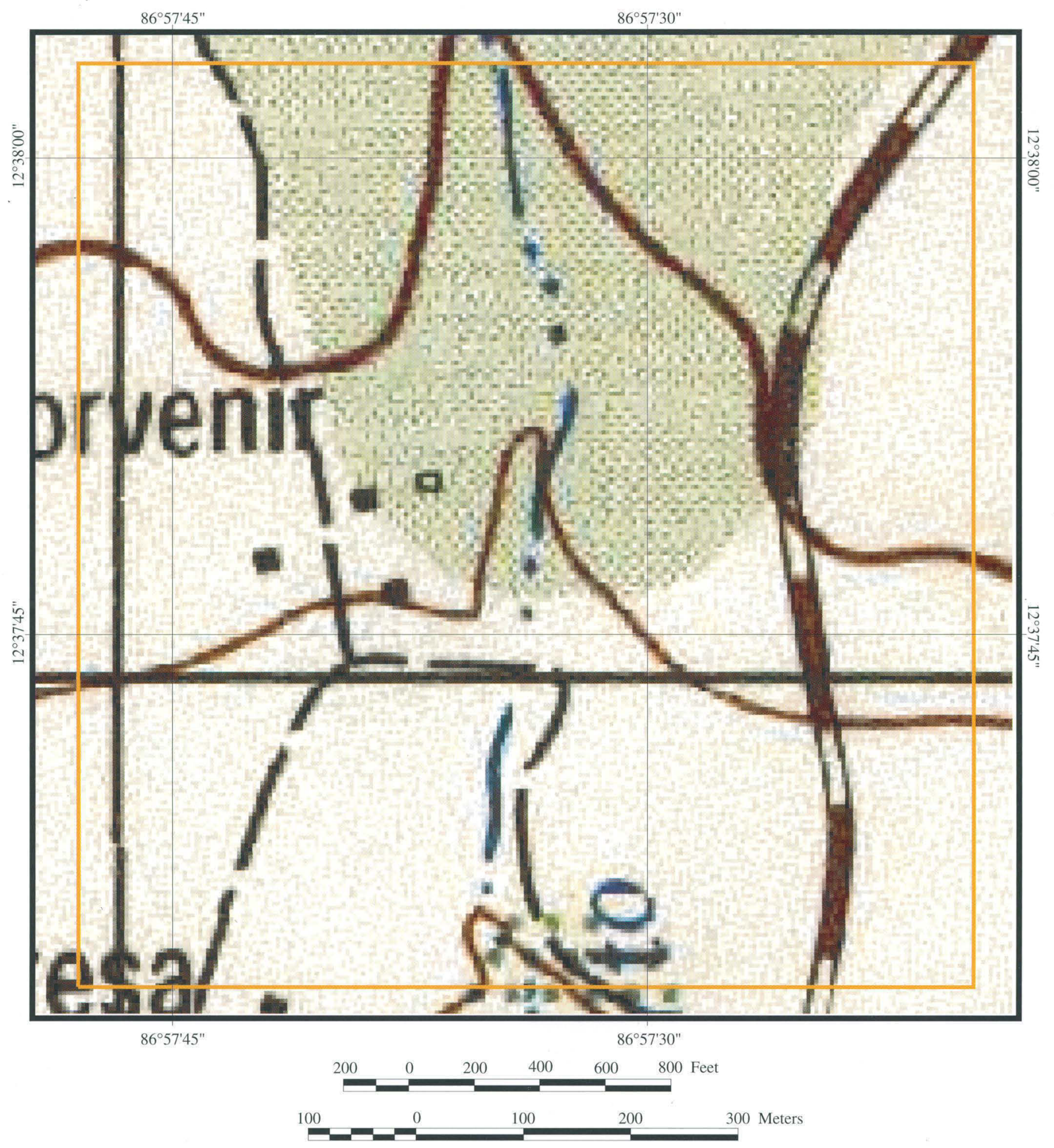

Map Source: 1:50,000-scale DMA topographic map of Nicaragua 


\section{El Porvenir \& Rolando Rodriguez, Nicaragua}

\section{Frame 141-C; Enlargement: 17x}

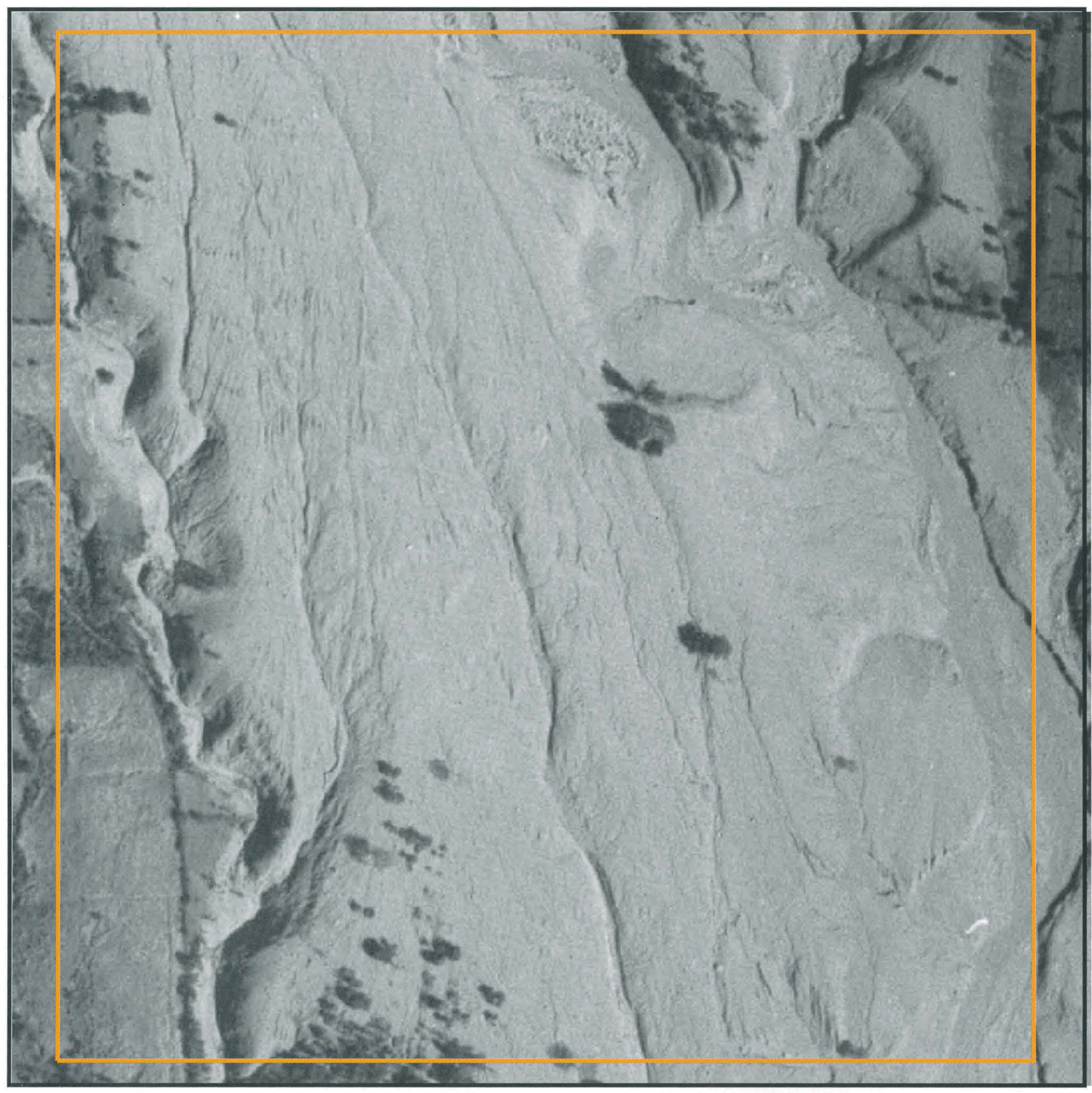

Frame 141-C, a 17x enlargement, showing the area previously occupied by the villages of El Porvenir and Rolando Rodriguez. Both villages were completely destroyed by the debris flow. The location of El Porvenir is shown on the accompanying map. Rolando Rodriguez, located to the east of El Porvenir, is not shown because its construction postdates the printing of the map. 


\section{El Porvenir, Nicaragua}

\section{Frame 141-D; Enlargement: 55x}

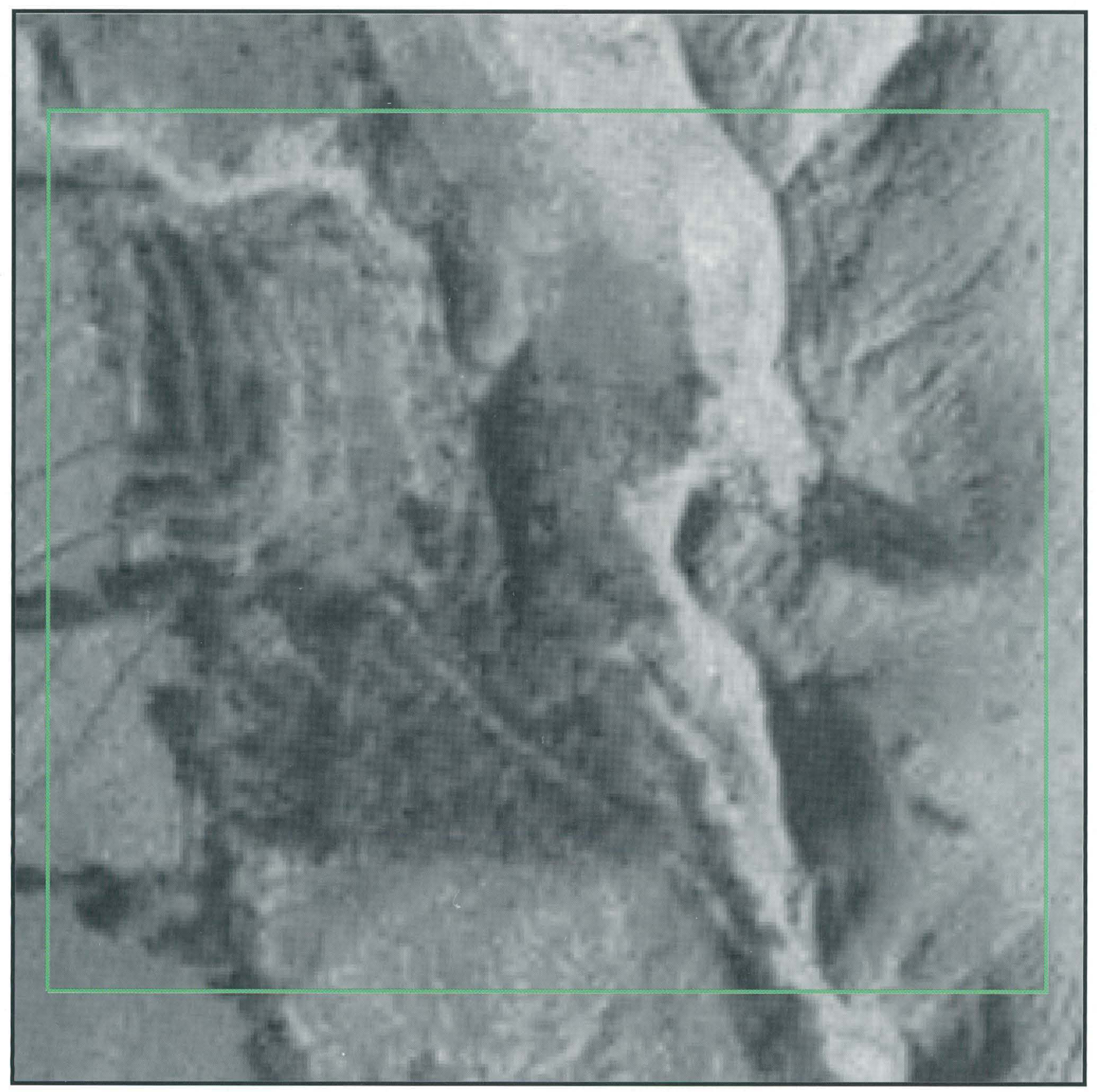

Frame 141-D, a 55x enlargement, showing a channel and levee that developed on the west side of the debris-flow deposits near the site of the village of El Porvenir. The village was located on the right edge of the photograph. The former location of the main road to the village cuts across the center of the enlargement. 


\section{USGS OBLIQUE COLOR PHOTOGRAPHS MADE OF SOME OF THE SAME AREAS SHOWN IN THE OPEN SKIES PHOTOGRAPHY}

USGS observers on the five OS flights provided advice and assisted the OS mission specialists.in making decisions about photographic targets. The USGS scientists also acquired 35-mm oblique color photographs of the areas affected by Hurricane Mitch. These photographs, when paired with the vertical photographs obtained by the OS optical cameras, provide additional information necessary to interpret the magnitude and intensity of the geologic processes triggered by the hurricane.

Fifteen selected examples of oblique color photographs taken by USGS geologist Bruce F. Molnia on December 15, 1998, are shown on the following pages. These oblique photographs are on the enclosed CD-ROM and the World Wide Web. 


\section{South Flank, Casita Volcano, Nicaragua}

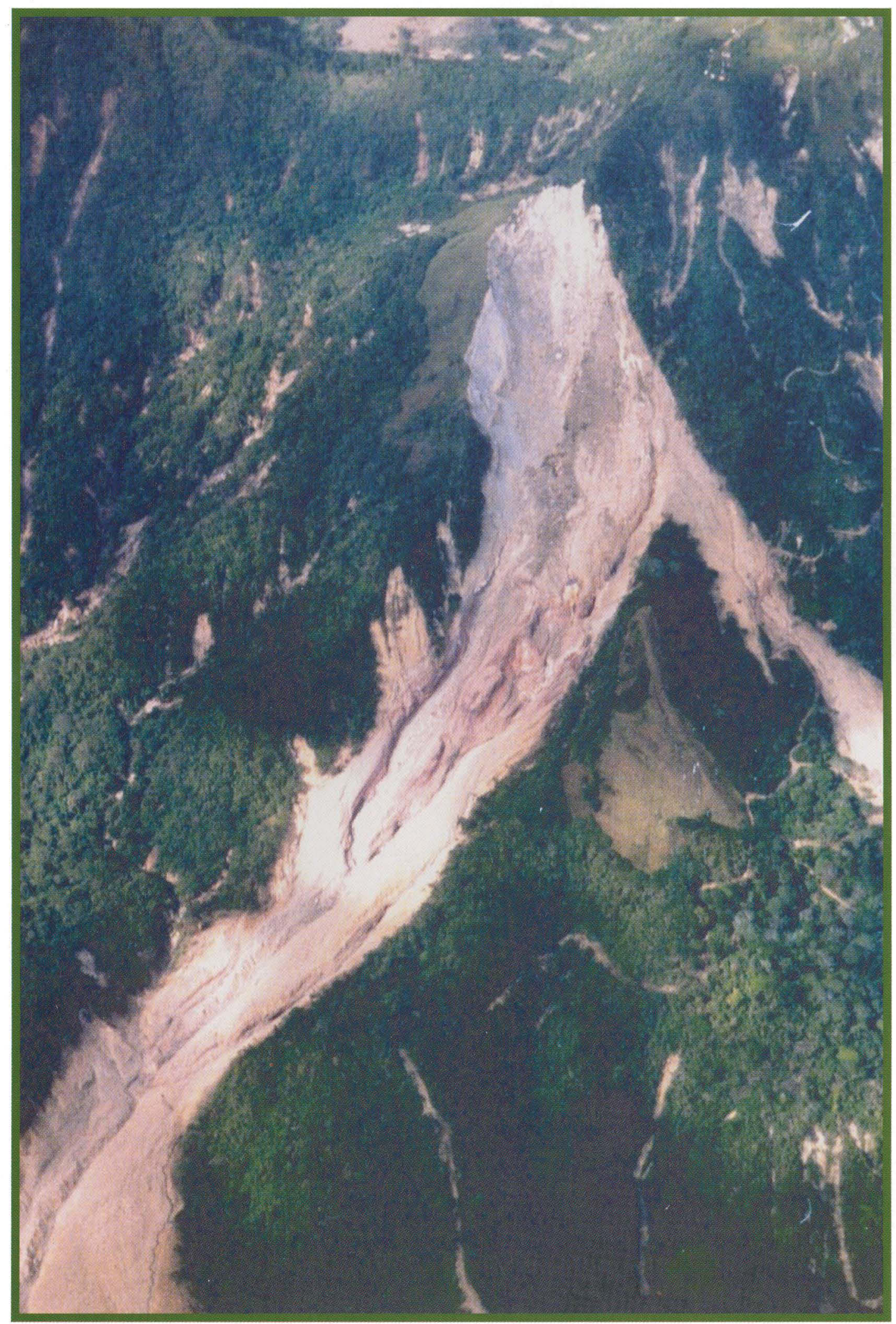

OS-34. A close-up of the location of the large rock avalanche on the south flank, just below the summit of Casita Volcano. Many smaller landslide scars are also visible. Compare with Open Skies vertical black-andwhite frame 141 and oblique color photograph OS-1. 


\section{Summit of Casita Volcano, Nicaragua}

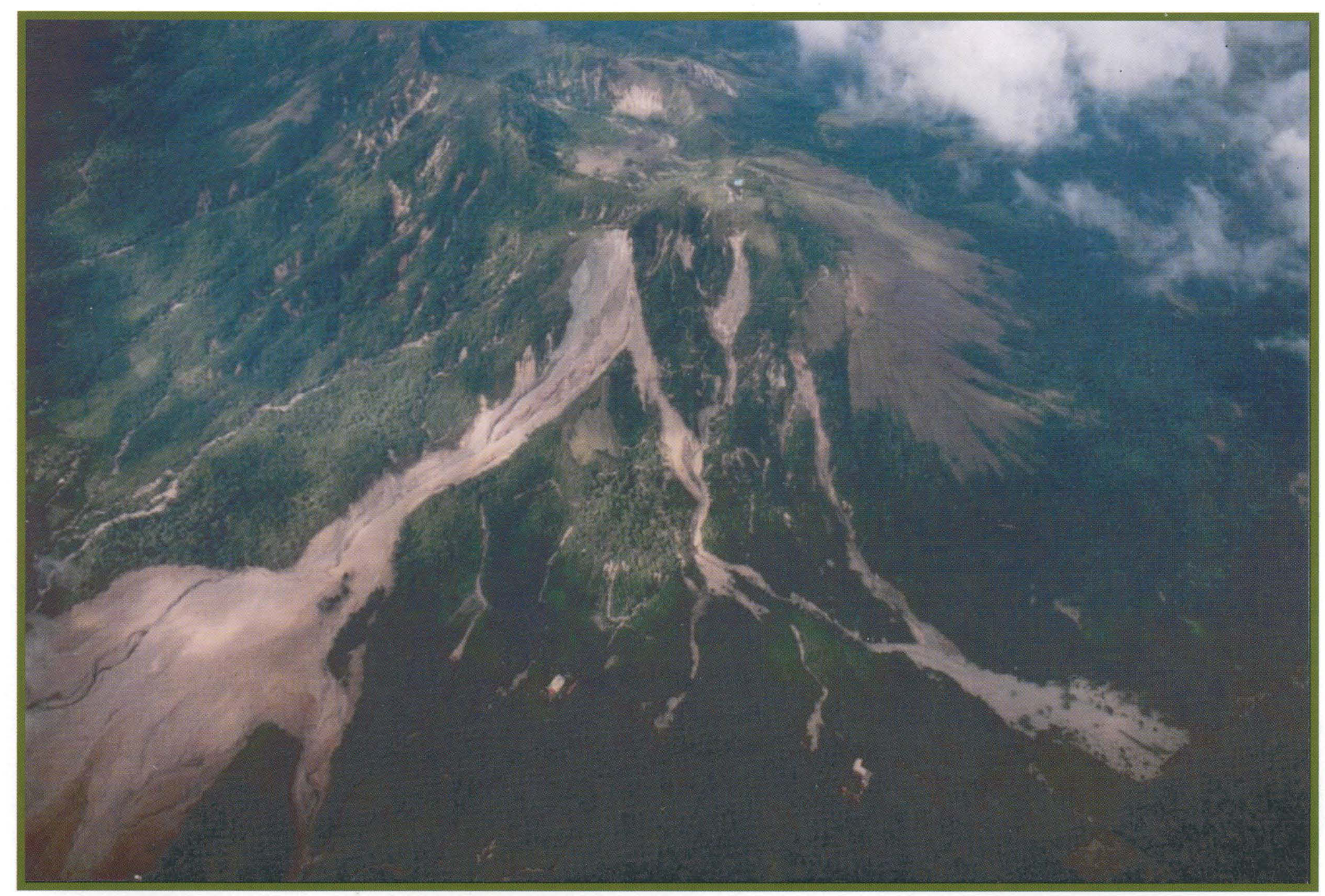

OS-1. Summit of Casita Volcano showing the locations of several large rock avalanches and many smaller landslide scars. Compare with Open Skies vertical blackand-white frame 141. 


\section{Summit of San Cristobal Volcano, Nicaragua}

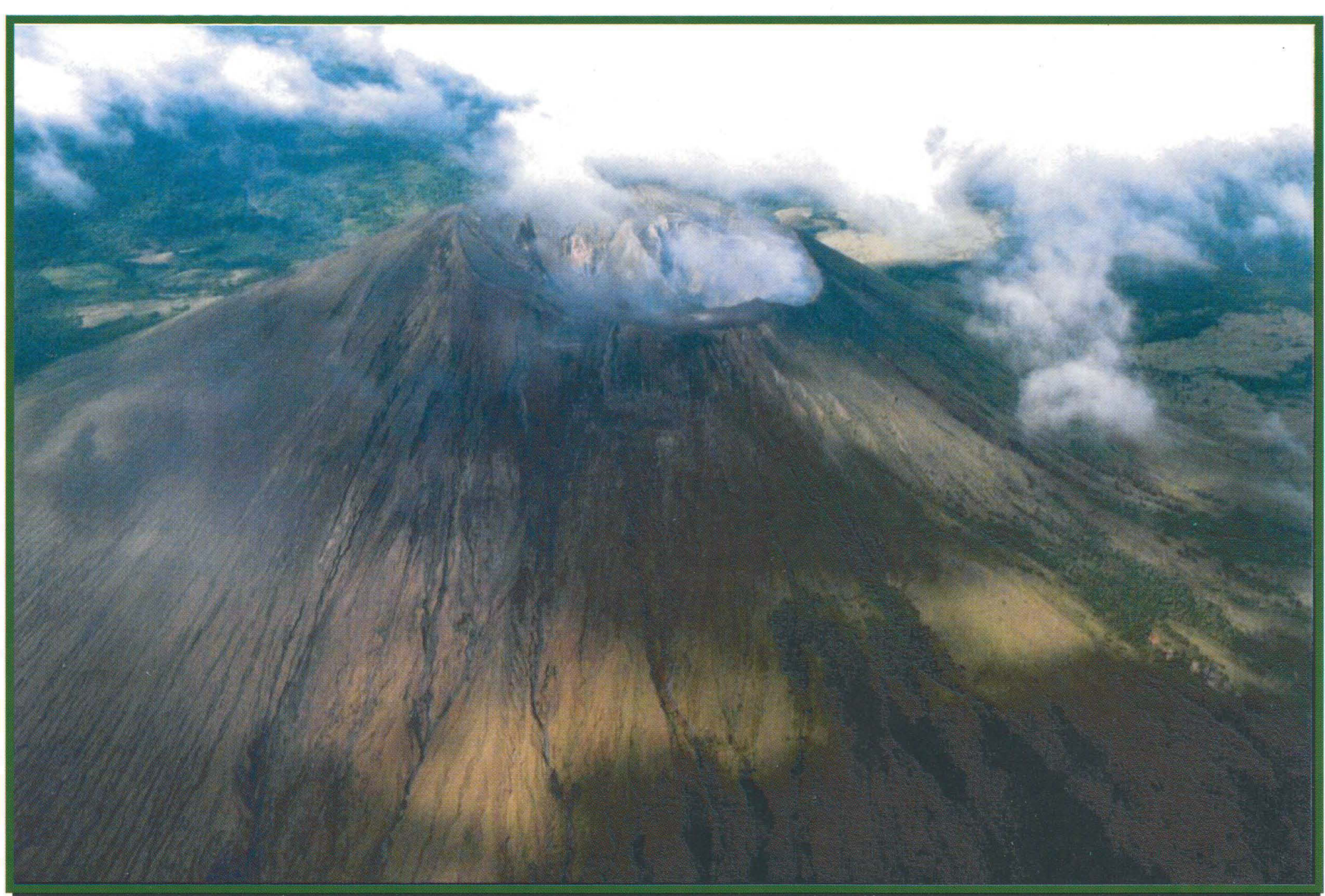

OS-2. Summit of San Cristobal Volcano showing hundreds of parallel and subparallel rills and gullies cut into the surface of the volcano by the huge volume of precipitation that fell during Hurricane Mitch. 


\section{Lago de Managua, Nicaragua}

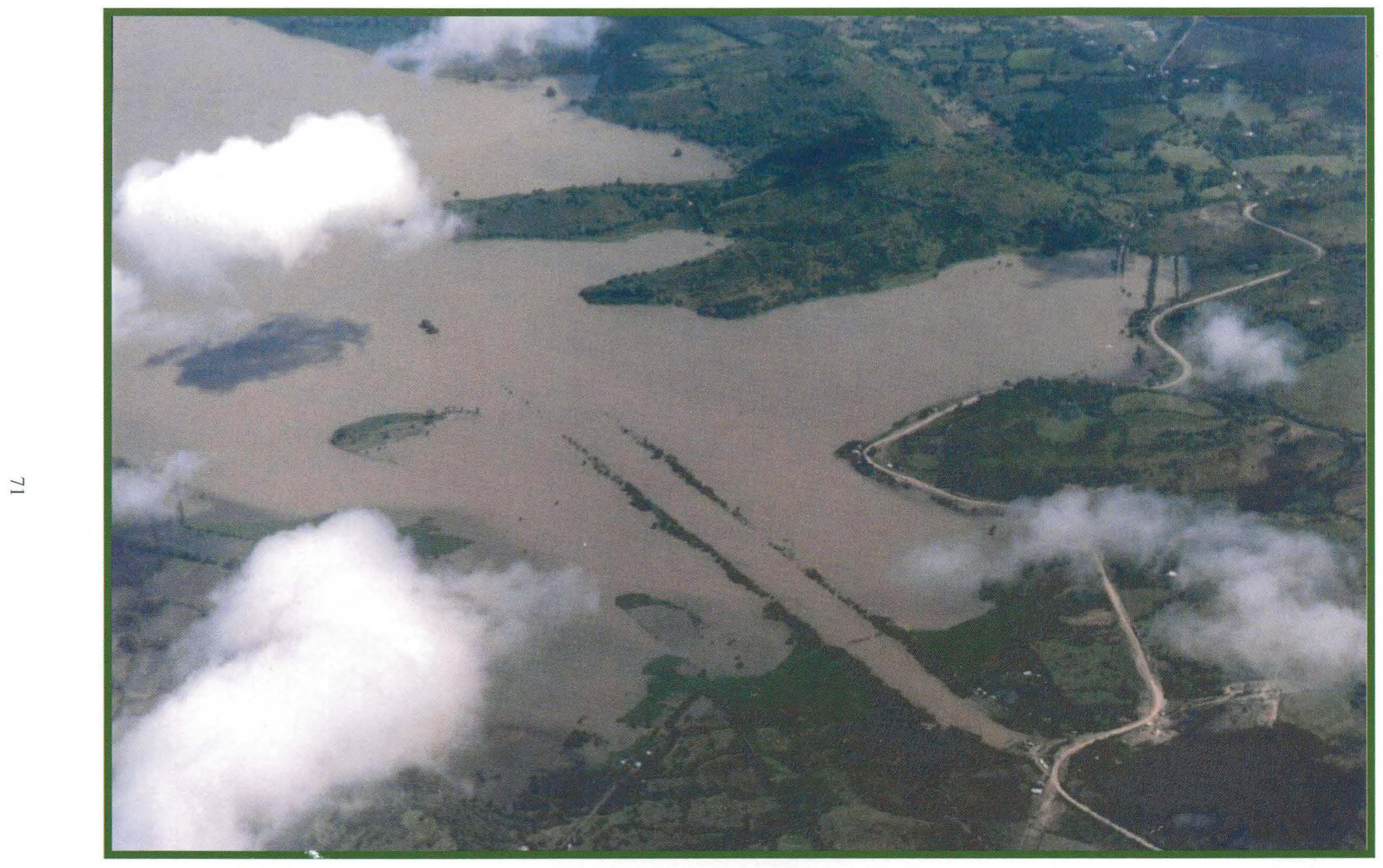

OS-18. Lago de Managua and other Nicaraguan lakes suffered significant flooding. Here, northwest of Managua, numerous farm buildings and fields are under water. The water level rose as much as 15 feet in some lakes. Compare with Open Skies vertical black-and-white frame 427. 


\section{Honduras-Nicaragua Border Area}

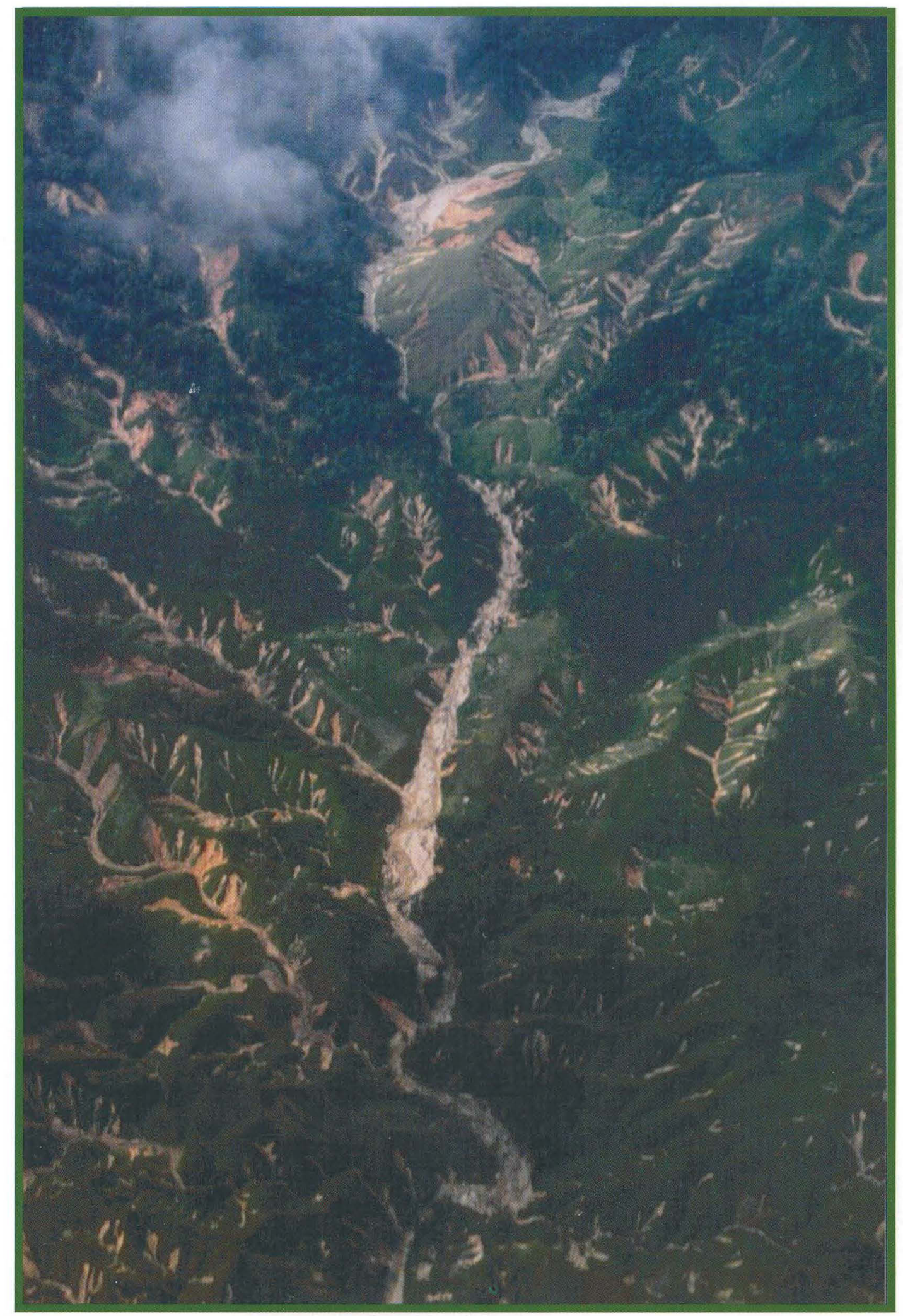

OS-32. The greatest concentration of landslides seen in any of the areas affected by Hurricane Mitch occurred in the mountainous Honduras-Nicaragua border region, northeast of Choluteca. As this region is sparsely populated, little property damage resulted here. Compare with Open Skies vertical black-and-white frames 217, 255, and 420 . 


\section{Honduras-Nicaragua Border, North of Chinandega}

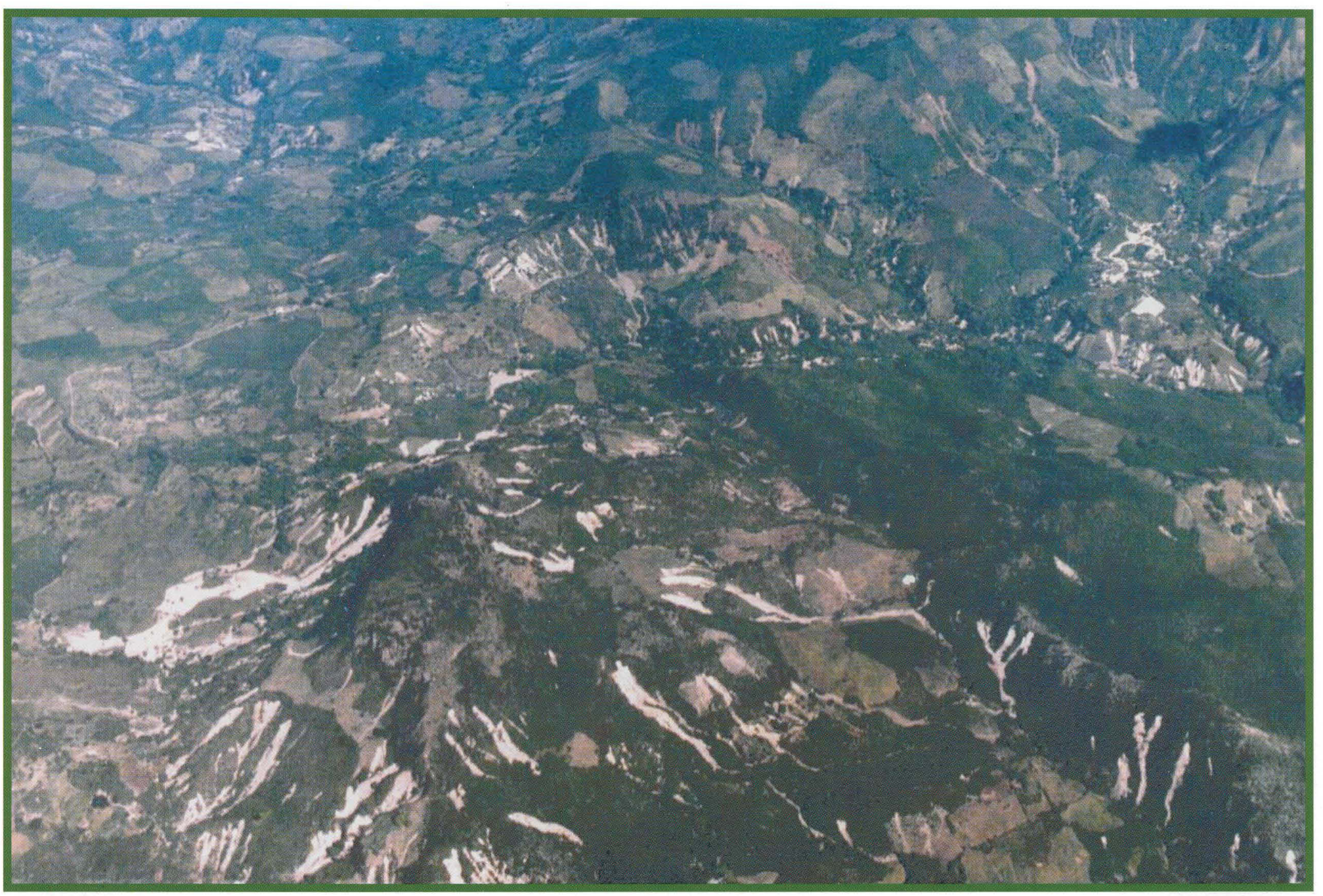

OS-12. Numerous landslides occurred in the mountainous Honduras-Nicaraguan border region, north of Chinandega. As this region is sparsely populated, little property damage resulted here. Compare with Open Skies vertical black-and-white frames 217,255 , and 420. 


\section{South-central Honduras}

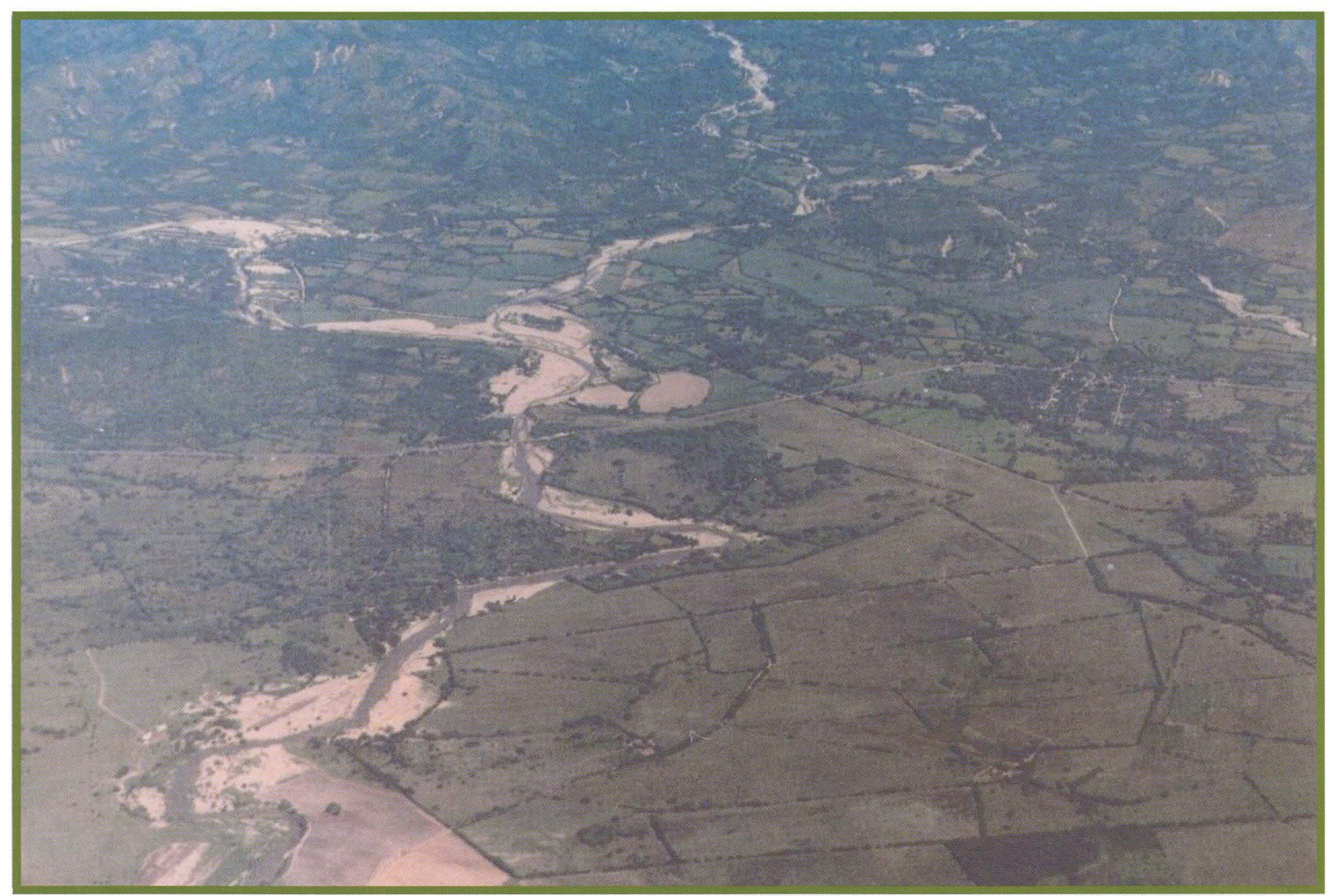

OS-15. This upland area shows significant sediment deposition along the banks and on the floodplain of all of the rivers in this area. Compare with Open Skies vertical black-and-white frames 296 and 316 


\section{South-central Honduras}

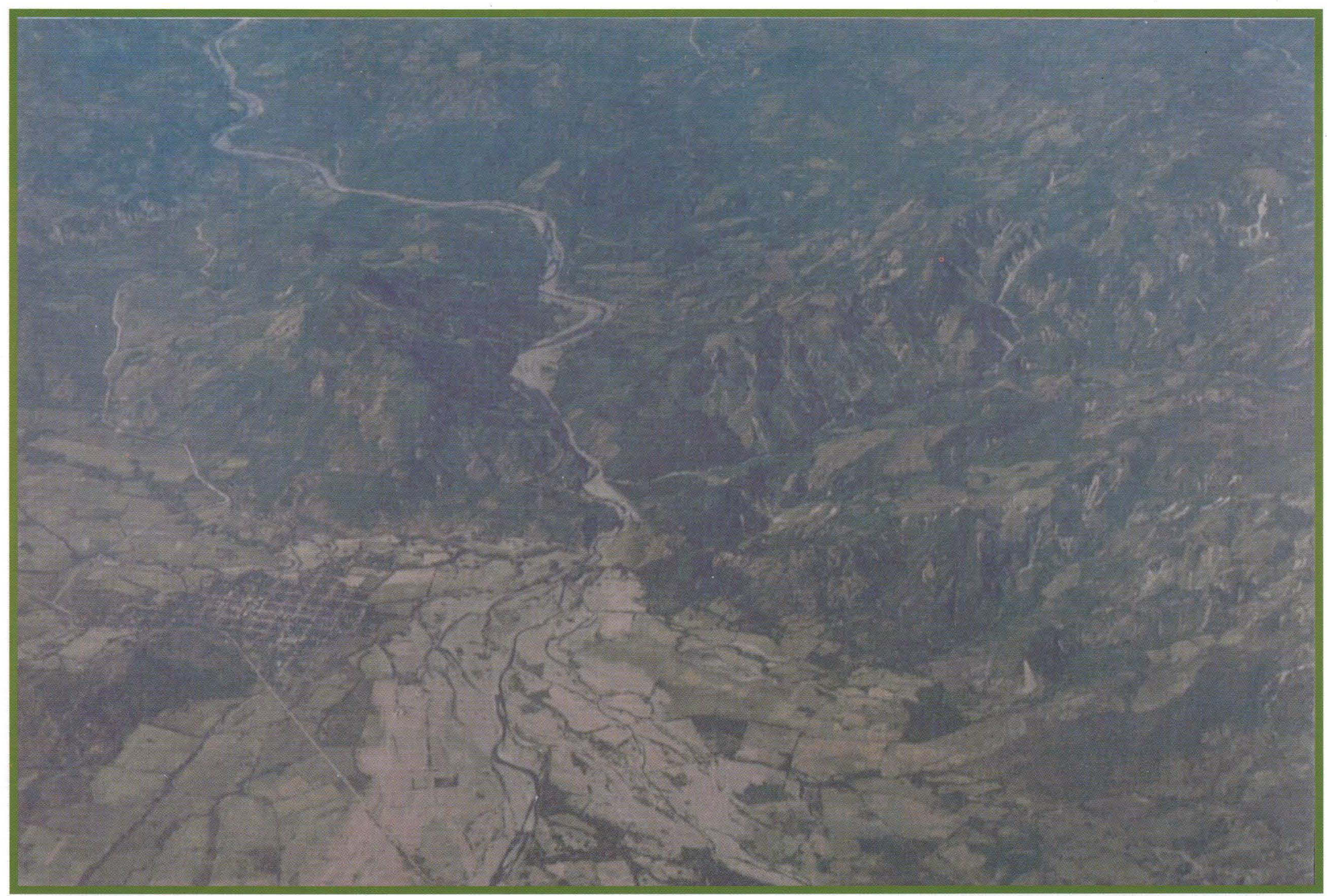

OS-27. When a high-velocity, steep-gradient, sediment-laden river reaches a valley floor, it rapidly deposits its sediment load. Here, at the foot of the mountains, an area larger than a square mile is covered by recently deposited sediment. 


\section{Central Honduras, near Tegucigalpa}

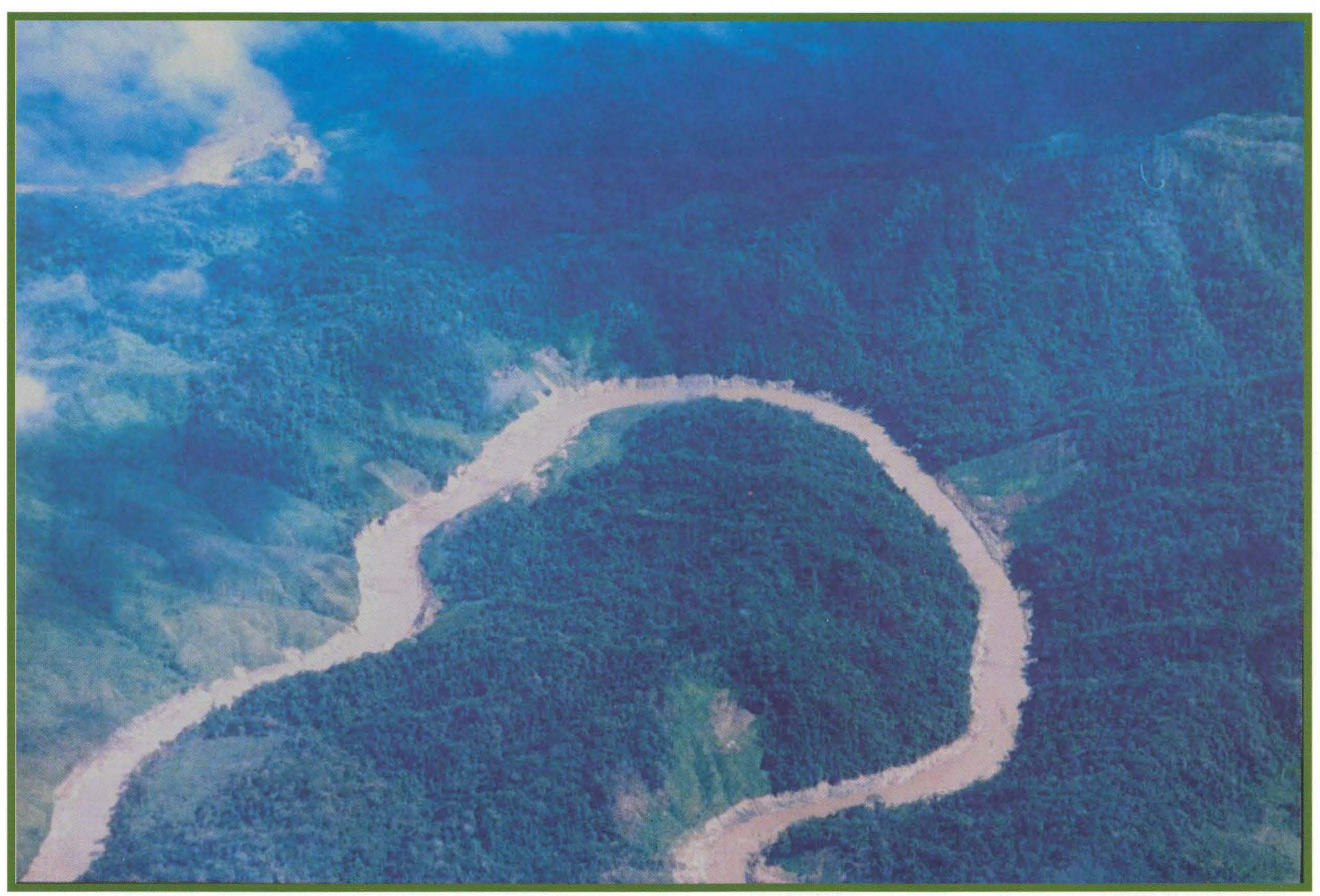

OS-20. Many upland rivers carried so much additional water and sediment during Hurricane Mitch that their banks were scoured many feet above their normal flow level. Here, significant amounts of bank erosion have occurred. 


\section{Southwest of Choluteca, Honduras}

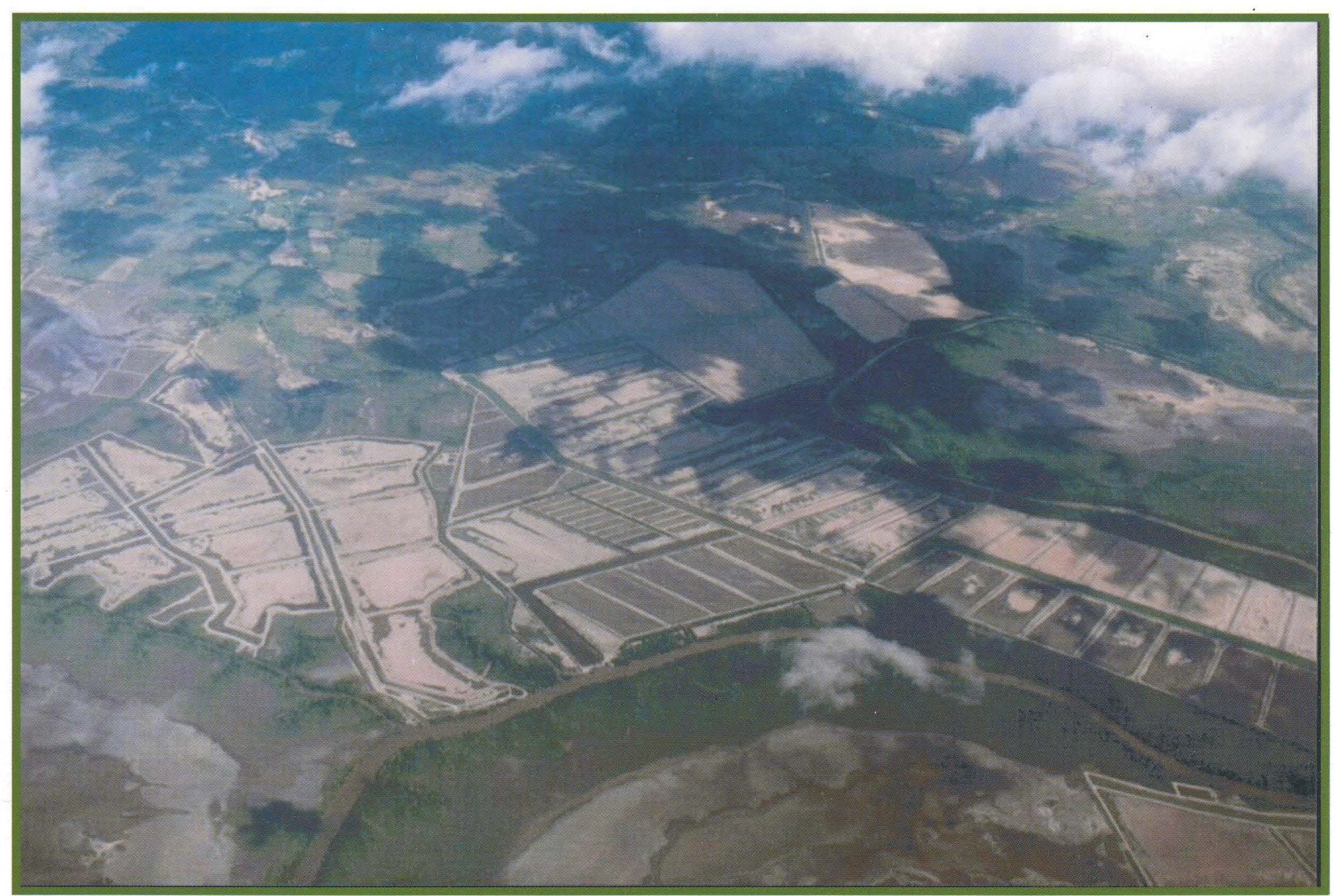

OS-5. Sediment deposited by flood waters during Hurricane Mitch filled many of the shrimp ponds in the coastal-plain area southwest of Choluteca, Honduras. Compare with Open Skies vertical black-and-white frames, 72, 94, 125, and 282. 


\section{Nacaome, Honduras}

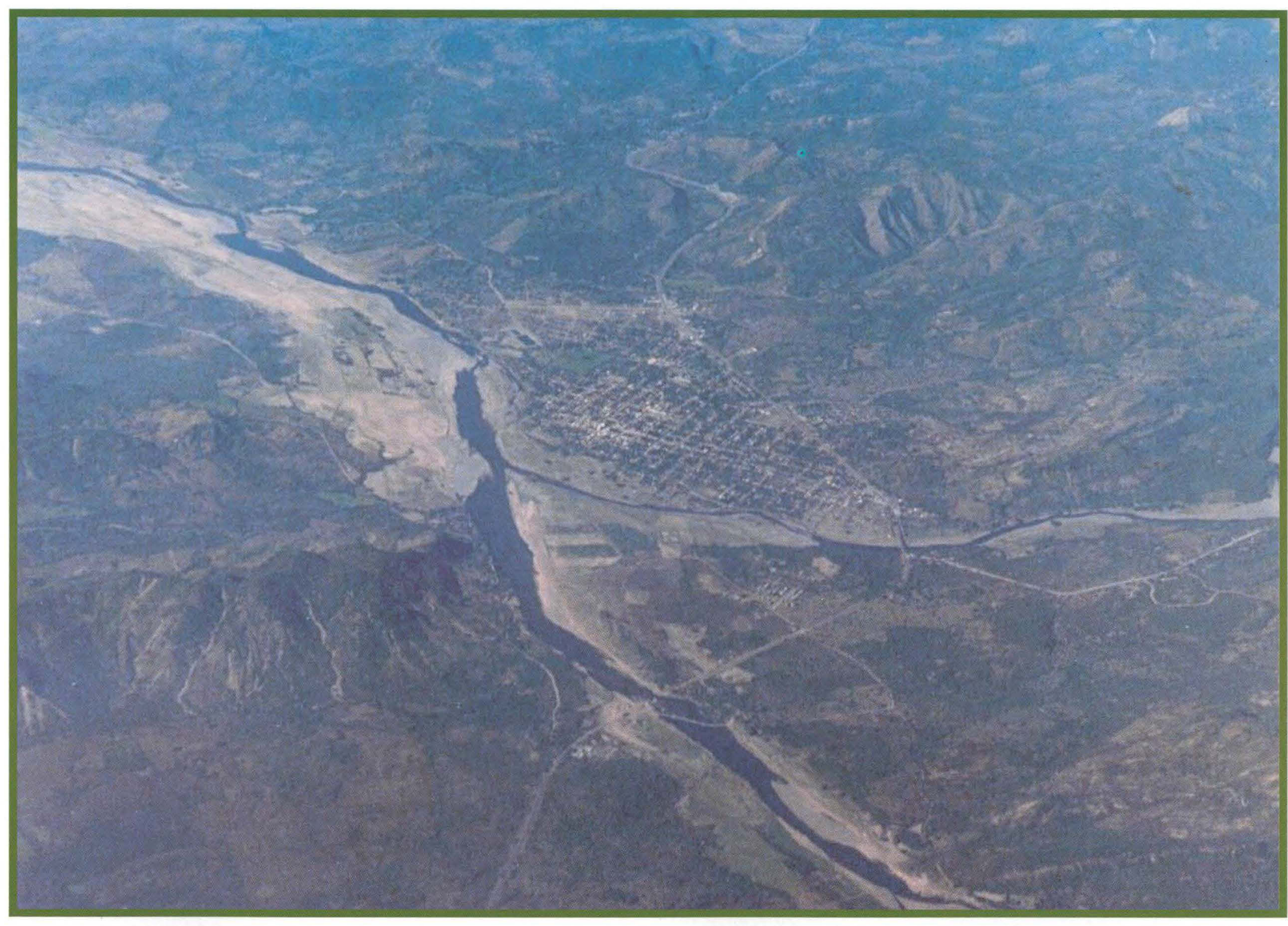

OS-24. Flooding deposited large quantities of sediment along the banks and on the floodplain of the Rio Nacaome near the southern Honduras city of Nacaome. Many manmade structures on the floodplain were destroyed, and parts of the city were flooded. Compare with Open Skies vertical black-and-white frame 96. 


\section{Choluteca, Honduras}

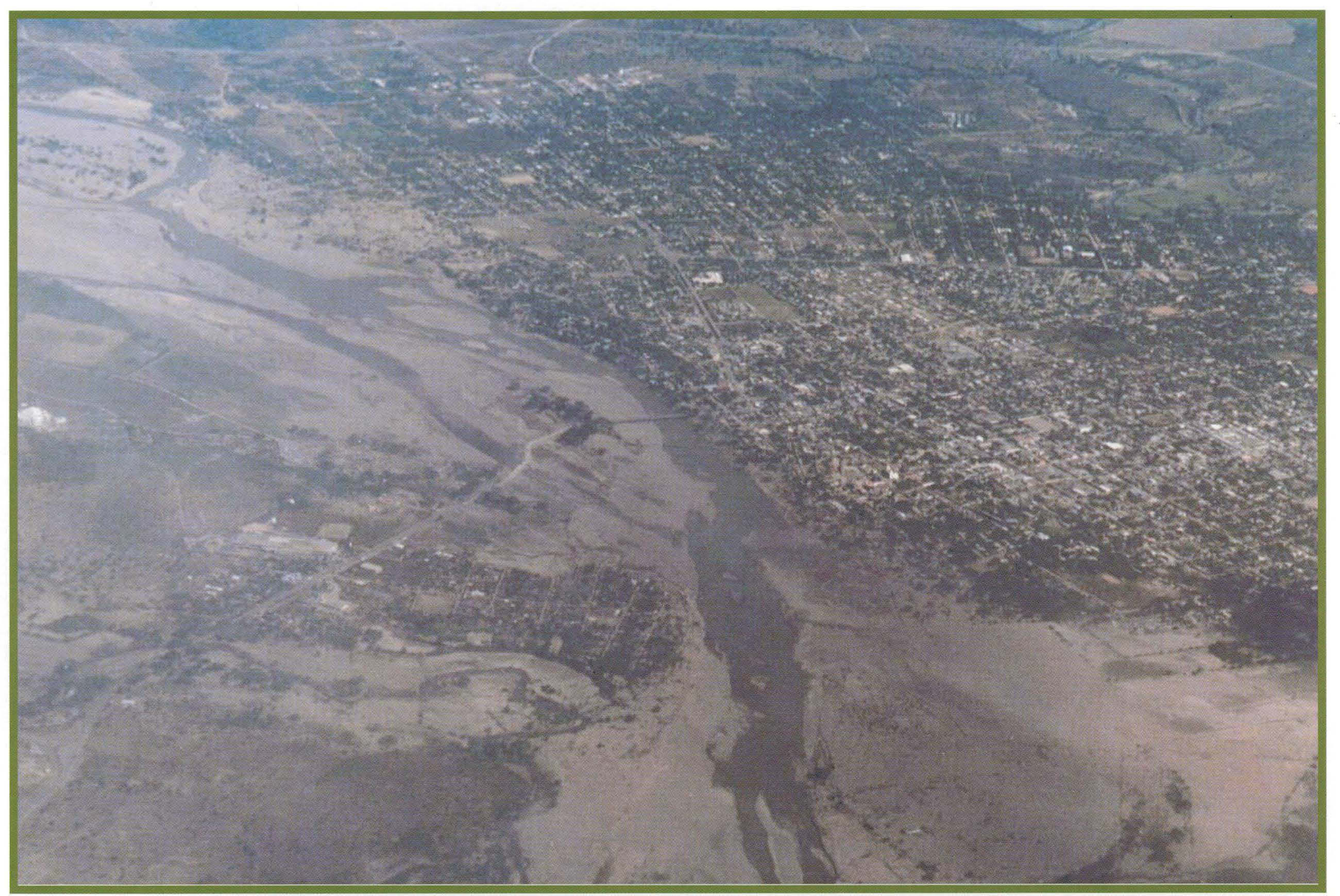

OS-14. Flooding deposited large quantities of sediment on the floodplain of the Choluteca River in the vicinity of the city of Choluteca, southern Honduras. Much of the northern part of the city was flooded. Buildings in some areas were buried by sediment. Compare with Open Skies vertical black-and-white frame 257. 


\section{Choluteca River, North of Marcovia, Honduras}

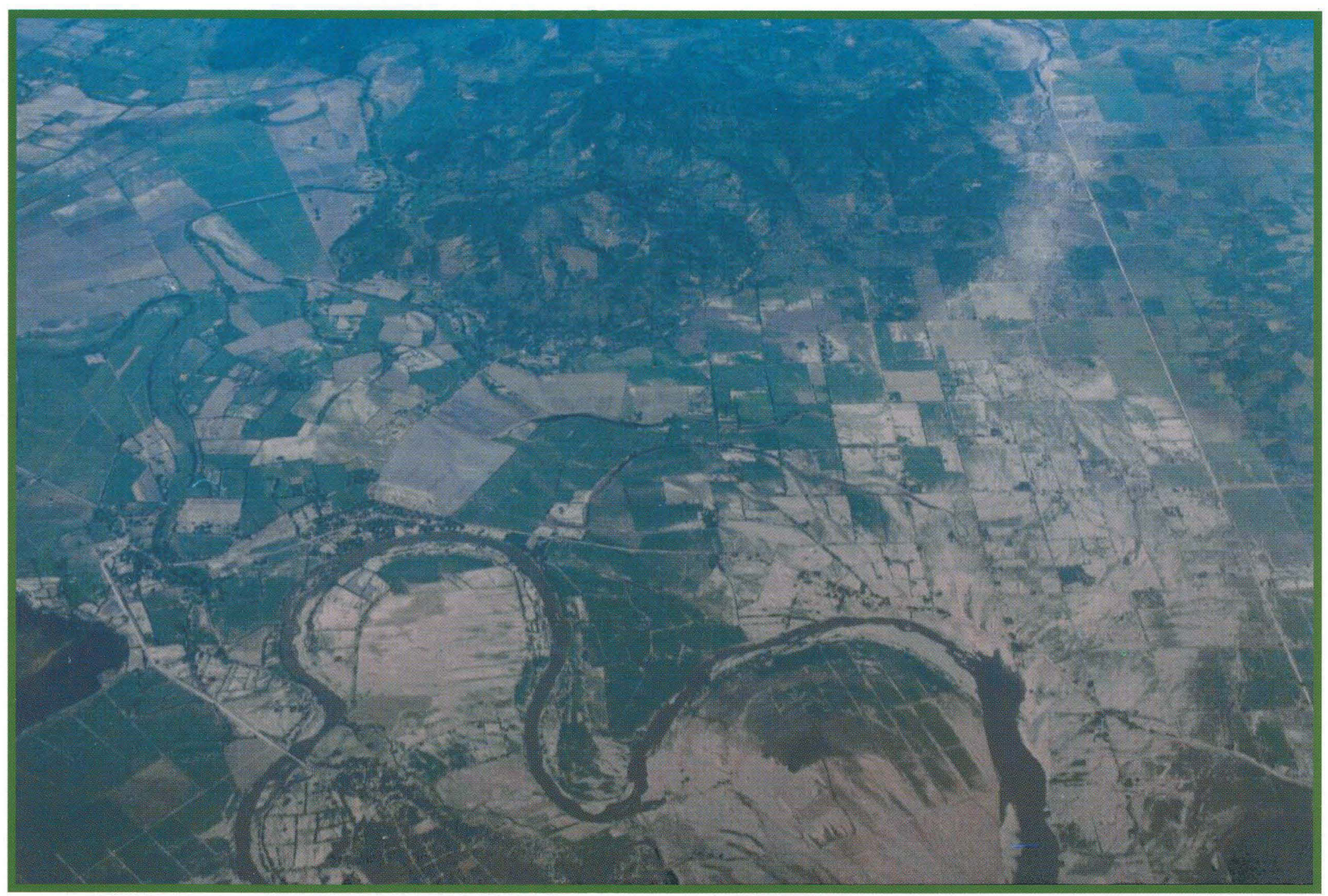

OS-23. Flooding deposited large quantities of sediment on the coastal plain adjacent to the Choluteca River, near Marcovia, Honduras. Here, water from the river cut a new channel to the west (upper right of the photograph), scouring the land surface as it flowed. Compare with oblique color photograph OS-33. 


\section{Choluteca River, Honduras}

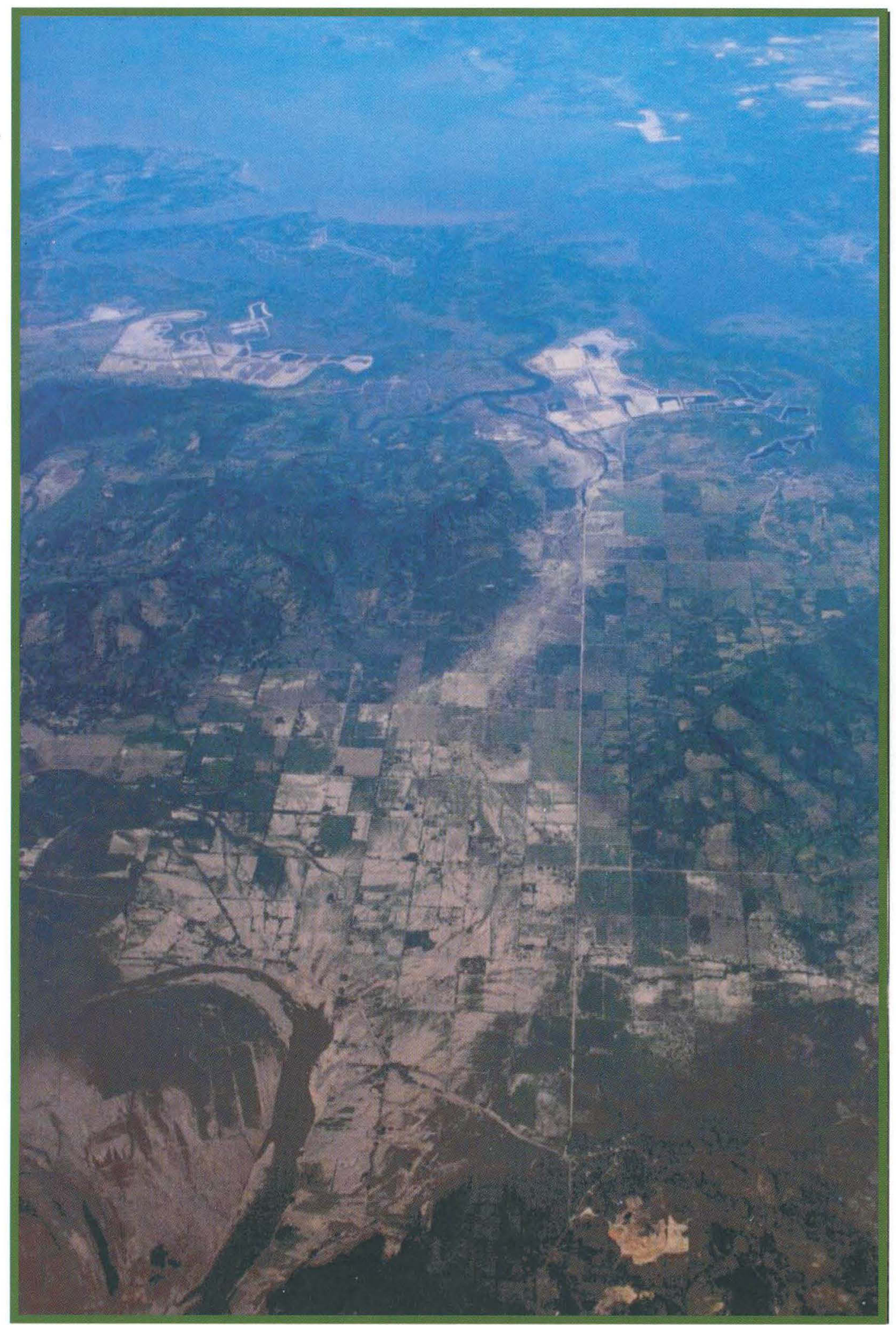

OS-33. Flooding deposited large quantities of sediment on the coastal plain adjacent to the Choluteca River, near Marcovia, Honduras. Here, water from the river formed a new channel, draining to the west toward the Gulf of Fonseca, at the top of the photograph. Compare with oblique photograph OS-23. 


\section{Aguan River near Trujillo, Honduras}

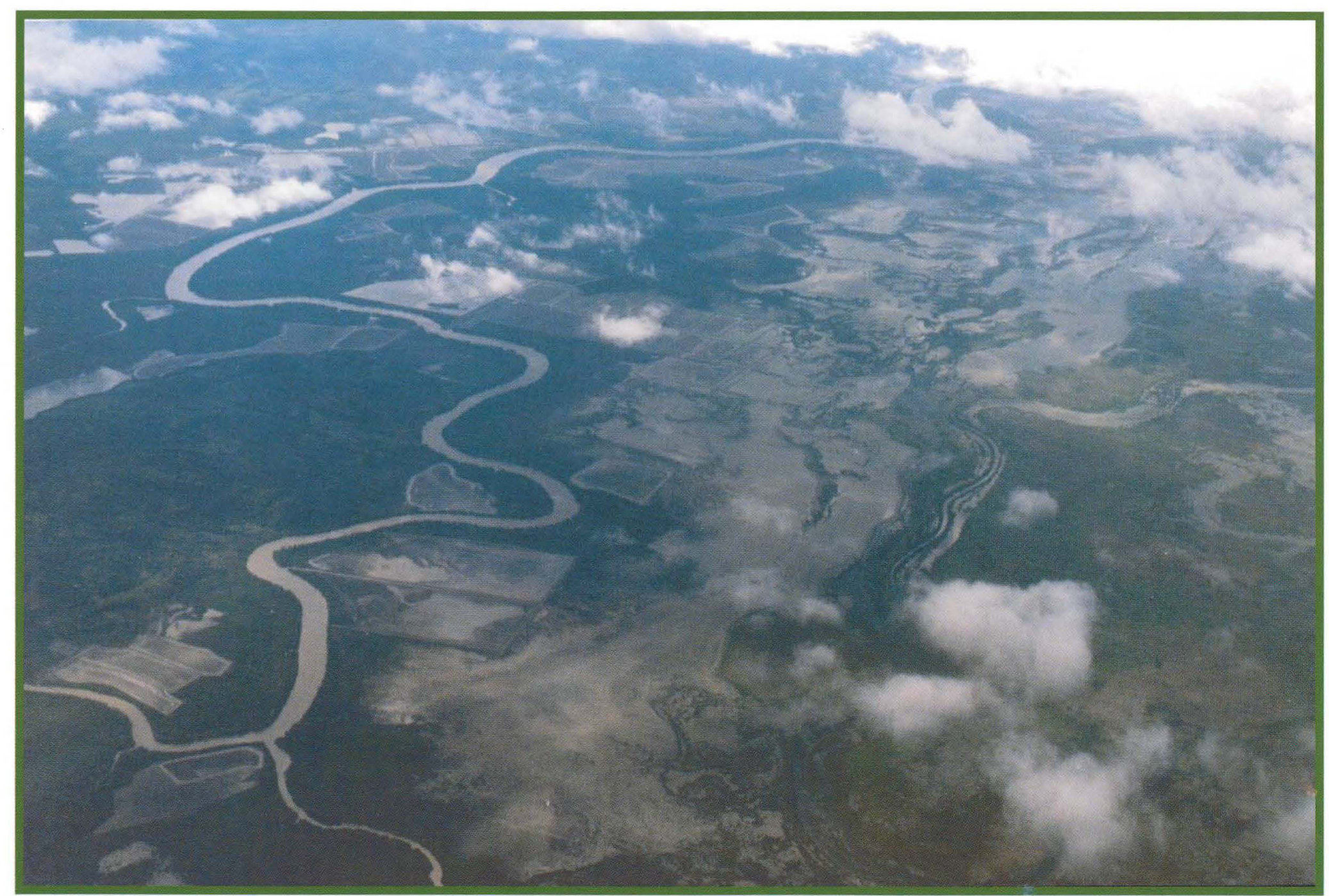

OS-7. More than 6 weeks after the end of Hurricane Mitch, large areas of the Aguan River valley, near Trujillo, Honduras, were still covered by standing water. Many agricultural enterprises suffered significant flood damage. 
This CD-ROM contains a digital version of the entire Circular plus full-resolution image files of the maps and photographs used in the publication.

\section{GETTING STARTED -}

The Open Skies text on this disc (CIRC1181.PDF) is in Portable Document

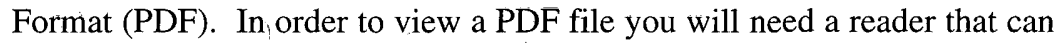
translate PDF files. The Acrobat directory contains installers for Adobe Acrobat Reader 4.0 for both Windows (PC directory) and Macintosh (MAC directory): Access the ASCII format README.TXT file for "getting started" instructions on installing Acrobat Reader from this CD-ROM if needed.

If you have Acrobat Reader, (or an equivalent) installed, start the program, click on "File", and then click on "Open ".

Macintosh:

Click the Destop button, Double-click CIRC_1181, Double-click CIRC1181.PDF.
Windows:

Click the "down arrow", Double-click CIRC_1181 Double-click CIRC1181.PDF. 


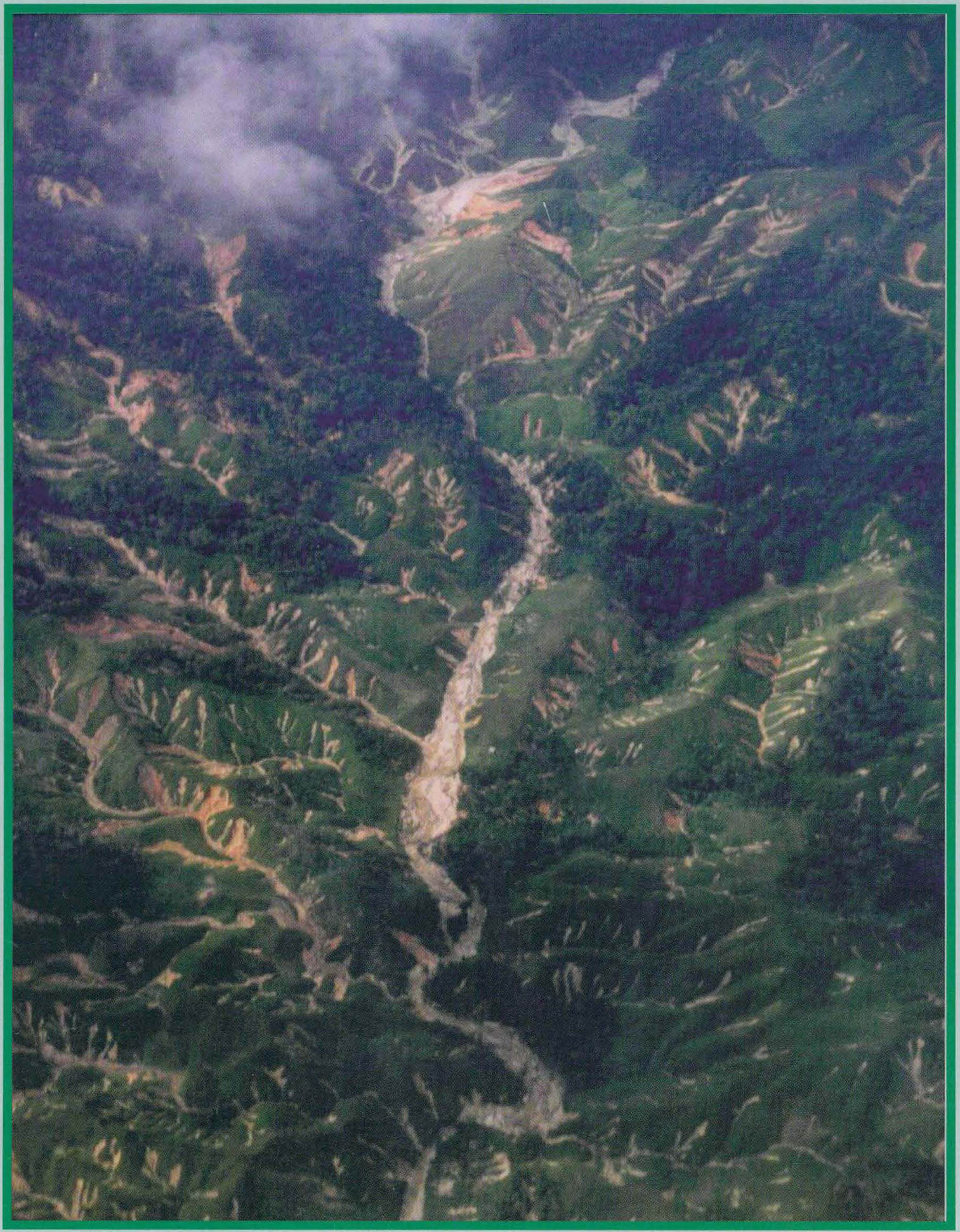

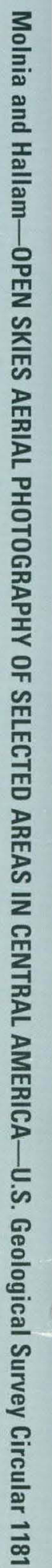

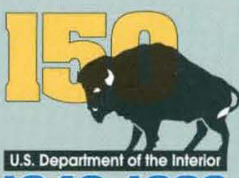

$1849 \cdot 1999$

Printed on recycled paper

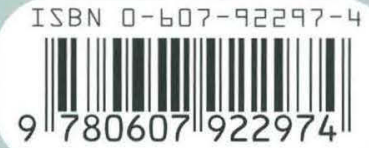

